UNIVERSIDADE DE SÃO PAULO

FACULDADE DE ECONOMIA, ADMINISTRAÇÃO E CONTABILIDADE DEPARTAMENTO DE CONTABILIDADE E ATUÁRIA PROGRAMA DE PÓS-GRADUAÇÃo EM CIÊNCIAS CONTÁBEIS

\author{
RELAÇÃO DA ESTRUTURA DE CUSTOS E DESPESAS \\ COM A RENTABILIDADE E LUCRATIVIDADE OPERACIONAL \\ NOS SETORES TÊXTIL E SIDERÚRGICO/METALÚRGICO NO BRASIL \\ NO PERÍODO DE 2005 A 2009
}

Bruno Carlos de Souza

Orientador: Prof. Dr. Welington Rocha

SÃO PAULO

2011 
Prof. Dr. João Grandino Rodas

Reitor da Universidade de São Paulo

Prof. Dr. Reinaldo Guerreiro

Diretor da Faculdade de Economia, Administração e Contabilidade

Prof. Dr. Edgard Bruno Cornachione Jr.

Chefe do Departamento de Contabilidade e Atuária

Prof. Dr. Luís Eduardo Afonso

Coordenador do Programa de Pós-Graduação em Ciências Contábeis 


\section{RELAÇÃO DA ESTRUTURA DE CUSTOS E DESPESAS COM A RENTABILIDADE E LUCRATIVIDADE OPERACIONAL NOS SETORES TÊXTIL E SIDERÚRGICO/METALÚRGICO NO BRASIL NO PERÍODO DE 2005 A 2009}

Tese apresentada ao Departamento de Contabilidade e Atuária da Faculdade de Economia, Administração e Contabilidade da Universidade de São Paulo como requisito para obtenção do título de Doutor em Ciências Contábeis.

Orientador: Prof. Dr. Welington Rocha

Versão Corrigida

(Versão original disponível na Unidade que aloja o Programa)

\section{SÃO PAULO}


Tese apresentada ao Departamento de Contabilidade e Atuária da Faculdade de Economia, Administração e Contabilidade da Universidade de São Paulo - Programa de Pós-Graduação em Ciências Contábeis, examinado pela seguinte banca examinadora:

FICHA CATALOGRÁFICA

Elaborada pela Seção de Processamento Técnico do SBD/FEA/USP

Souza, Bruno Carlos de

Relação da estrutura de custo e despesa com a rentabilidade e lucratividade operacional nos setores têxtil e siderúrgico/metalúrgico no Brasil do período de 2005 a 2009 / Bruno Carlos de Souza. -- São Paulo, 2011.

$142 \mathrm{p}$.

Tese (Doutorado) - Universidade de São Paulo, 2011.

Orientador: Welington Rocha.

1. Custo industrial 2. Desempenho organizacional 3. Administração de custo I. Universidade de São Paulo. Faculdade de Economia, Administração e Contabilidade II. Título.

$\mathrm{CDD}-338.512$ 
Aos meus pais, irmã e noiva. 


\section{AGRADECIMENTOS}

Gostaria de agradecer a Deus pela minha saúde e segurança. Aos meus amigos e famíliares, pelo apoio e conversas, em especial para Moisés, Ilda, Bianca e Thaís. Aos professores do departamento de contabilidade da FEA/USP, que participaram do meu processo de aprendizagem durante todo o curso de doutorado. A equipe da FIPECAFI, do CMS Lab e do LABGER. Gostaria de enfatizar meu agradecimento aos professores que participaram da qualificação e da defesa deste trabalho. Em especial, gostaria de agradecer ao meu orientador, Prof. Welington Rocha, pela amizade, respeito e profissionalismo ao longo de nosso convívio. 
"Como o sol que brilha para o mundo, sem motivos pra brilhar... Viver é preciso sonhar!" 


\section{RESUMO}

A partir das demonstrações contábeis publicadas, com a utilização de modelagem econométrica, esta tese teve como objetivo principal estimar a composição da estrutura de custos e despesas que tiveram rentabilidade e lucratividade operacional acima da média dos setores selecionados. Extraíram-se inferências sobre a composição da estrutura de custos e despesas das empresas e efetuou-se uma análise relacionando essa estrutura com a rentabilidade e a lucratividade operacional acima da média de cada setor selecionado dentro do período de 2005 a 2009. As variáveis de análise foram extraídas da base de dados Economática. Foram selecionados os setores Têxtil e Siderurgia/Metalurgia, porque apresentaram maior quantidade de dados completos no período estudado. A técnica de modelagem quantitativa empregada foi a análise de regressão com dados em painel, com utilização do modelo de efeito fixo, com coeficiente angular constante e intercepto variando entre as entidades. A partir dos dados dos modelos, foi calculada a composição média de custos e despesas fixas (CDF) e custos e despesas variáveis (CDV) sobre o total de custos e despesas totais (CDT). Paralelamente, também foi calculada a margem operacional média (MO) e a rentabilidade operacional média (RO) dessas empresas para o mesmo período estudado. Além disso, uma breve discussão das características individuais de cada setor e uma análise do contexto econômico do período de 2005 à 2009 foi realizada para compreender possíveis influências no desempenho das empresas nos setores pesquisados. Desta análise constatou-se que o período com menor participação de CDF foi o ano de 2008, coincidindo com o período de intensificação da crise financeira nos mercados maduros. Com base na pesquisa realizada, constatou-se uma correlação forte e negativa entre CDF e os indicadores de desempenho (MO e RO). Constatou-se ainda que a estrutura de custos e despesas do setor Siderúrgico/Metalúrgico permite maior participação de CDF do que a do setor Têxtil. No setor Siderúrgico/Metalúrgico o intervalo da proporção de CDF nas empresas com desempenho acima da média no período foi de $30,34 \%$ a $30,60 \%$, enquanto que no setor Têxtil foi de $20,15 \%$ a $20,76 \%$. 


\begin{abstract}
The main objective of this dissertation is to estimate the composition of the cost and expense structure of companies using their published financial statements, with the use of econometric modeling. Inferences was drawn up for the composition of cost and expense structure of the companies and an analysis was made linking this structure with return on assets and operating profitability above average of each selected industry within the period 2005 to 2009. The variables of analysis have been extracted from Economática database. The Textile and Steel/Metallurgy industries were selected because they presented more complete data in the period investigated. The quantitative modeling technique employed was regression analysis with Panel data, using the fixed effect model with constant angular coefficient and intercept ranging between entities. Data from the models was calculated as the average composition of fixed costs and expenses (CDF) and variable costs and expenses (CDV) on the total costs and expenses (CDT). In parallel, was also calculated the average operating margin (MO) and the average operating return on assets (RO) of these companies for the same period. In addition, economic scenario data of the period was reviewed in order to identify if there was any possible significant influence on the variation of costs and expenses structure. The study results show that the period with lower participation of CDF was in 2008, coinciding with the period of intensification of the financial crisis in mature markets. Also the cost and expense structure with less participation of $\mathrm{CDF}$ is related to greater MO and RO. It was also found that the cost and expense structure of Steel/Metallurgical industry allows greater participation of CDF than the textile sector. In the Steel/Metallurgical industry, the percentage range of CDF in companies with above-average performance in the period was of $30.34 \%$ to $30.60 \%$, while in the Textile sector was of $20.15 \%$ to $20.76 \%$.
\end{abstract}




\section{SUMÁRIO}

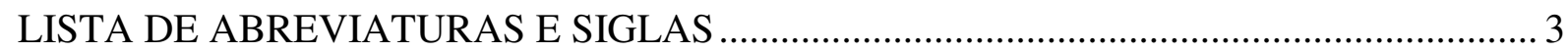

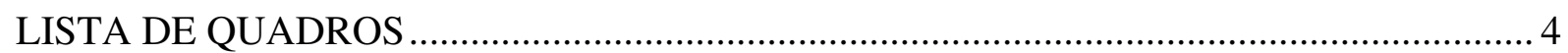

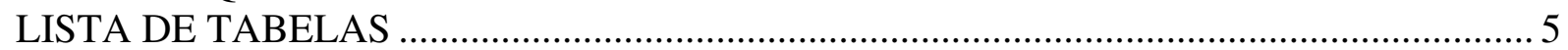

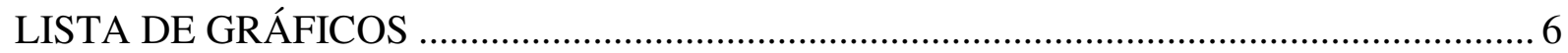

LISTA DE ILUSTRAÇÕES ...................................................................................... 7

1 CAMINHADA RUMO AO PROBLEMA OBJETO DO ESTUDO ............................. 9

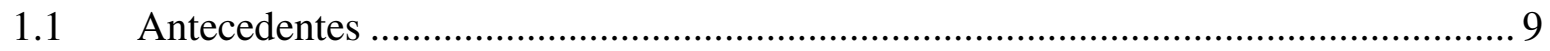

1.2 Caracterização da situação problema objeto de estudo .......................................... 10

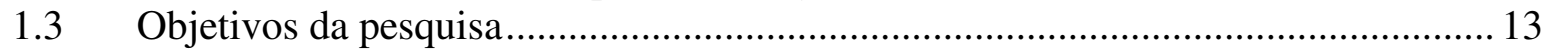

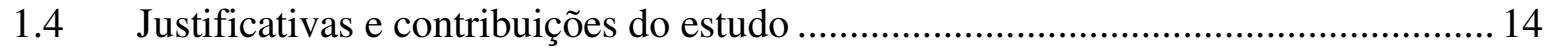

1.5 Delimitações do estudo: conceitual, temporal, setorial, geográfica e de foco ......... 17

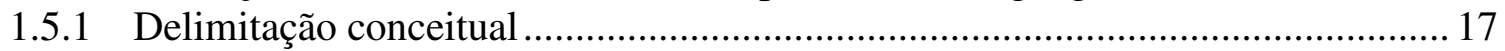

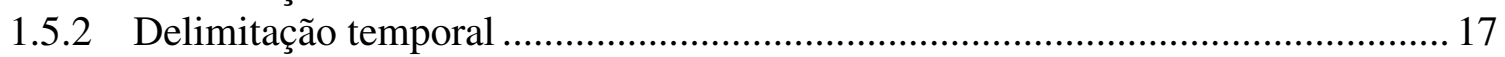

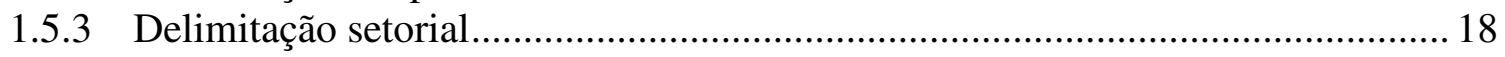

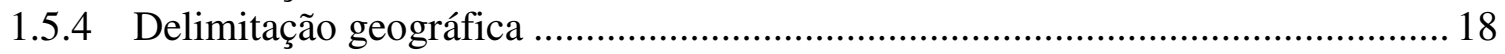

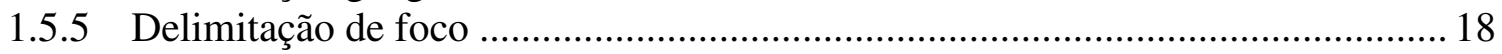

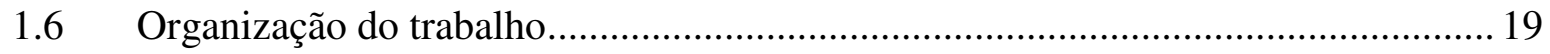

1.7 Formatação, referências bibliográficas e citações ................................................. 20

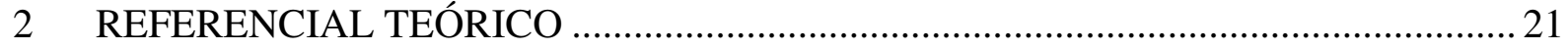

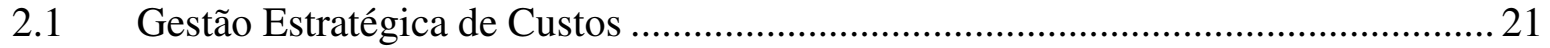

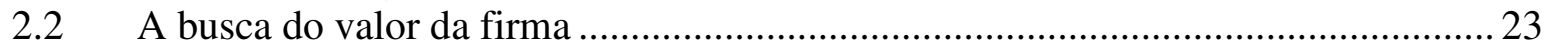

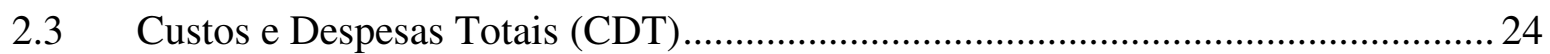

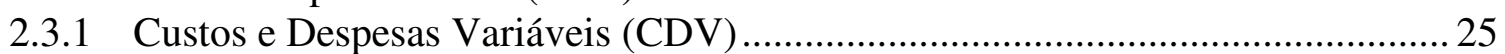

2.3.2 Custos e Despesas Fixas (CDF) ....................................................................... 26

2.3.3 Exemplo de situações baseadas na análise de CDV e CDF ................................2 28

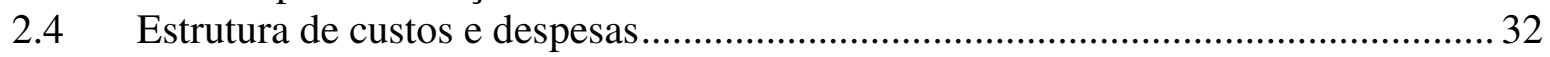

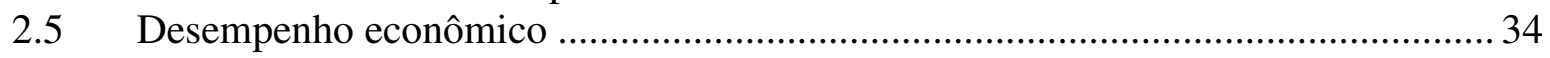

2.5.1 Desempenho mensurado com base na margem e no retorno operacional............ 34

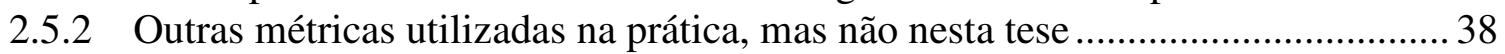

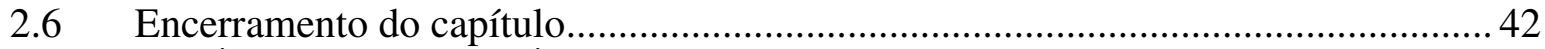

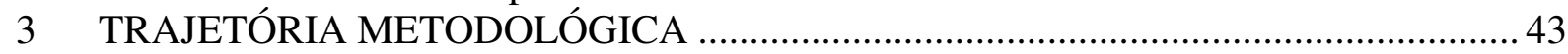

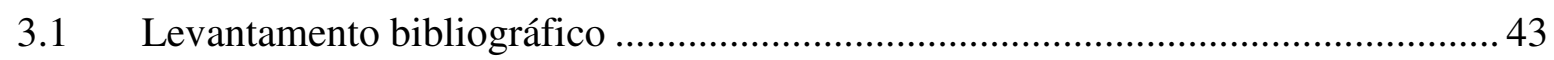

3.2 Amostra de empresas ................................................................................... 44

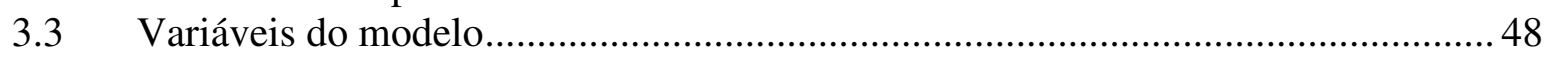

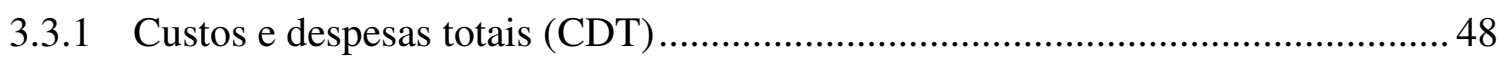

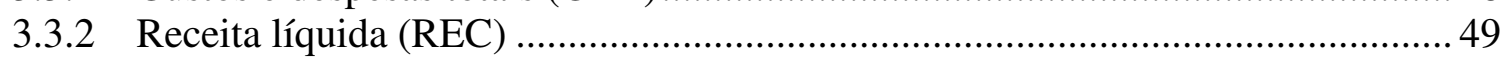

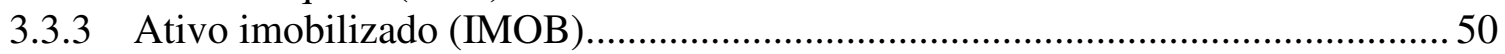

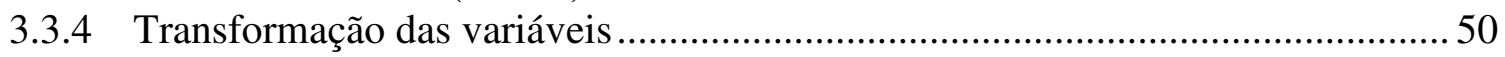

3.4 Modelos de regressão com dados em painel ...................................................... 51

3.5 Estimando os modelos de regressão com dados em painel .......................................53

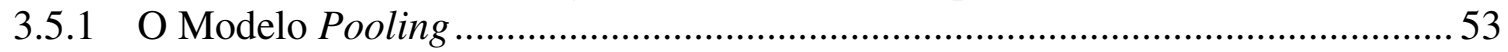

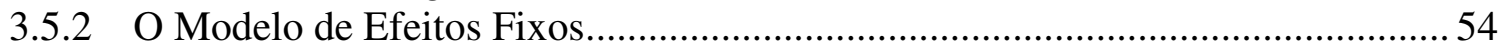

3.5.3 O Modelo de Efeitos Aleatórios ......................................................................... 55

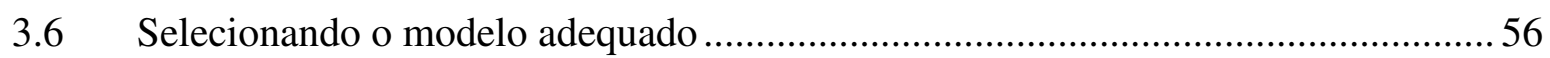

3.7 Estimando a estrutura de custos e despesas das amostras ......................................... 57

3.8 Identificação da relação entre estrutura de custo e despesa ................................... 60

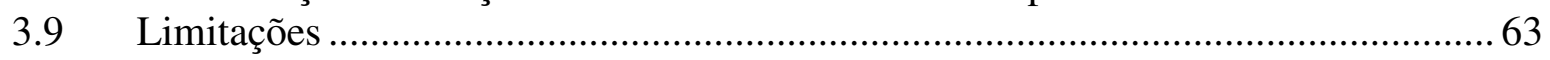




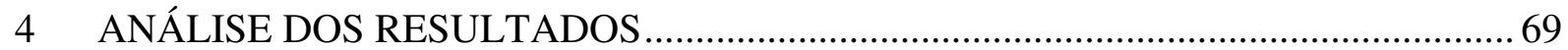

4.1 Cenário econômico no Brasil e no mundo no período estudado ................................ 69

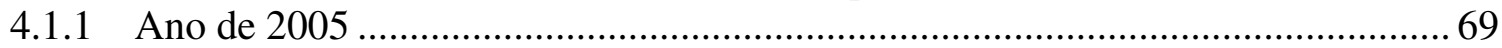

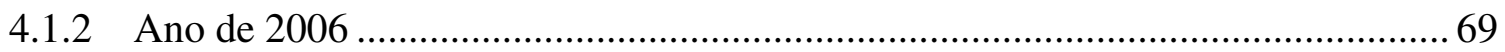

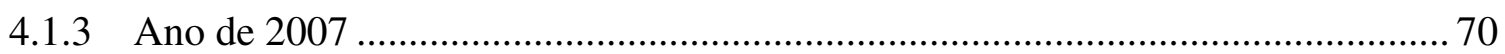

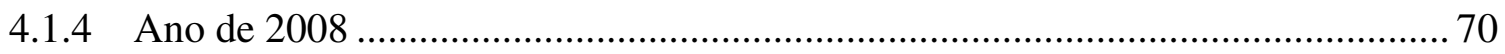

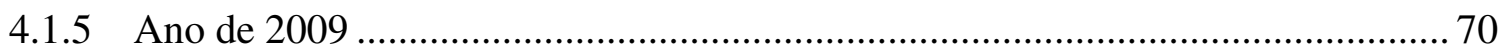

4.1.6 Reflexo do cenário econômico nos setores estudados ....................................... 71

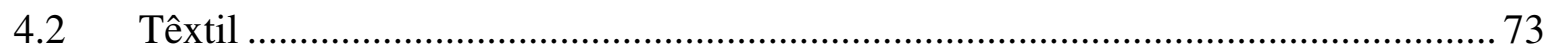

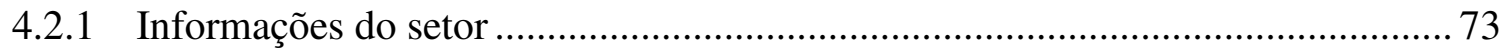

4.2.2 Análise dos dados da amostra de empresas do setor ......................................... 74

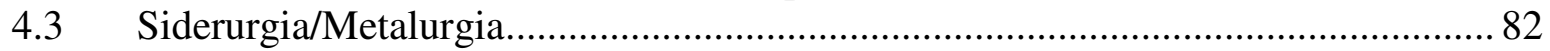

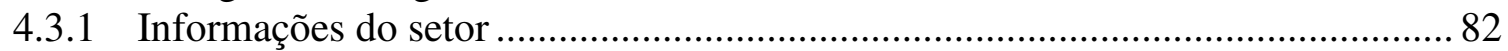

4.3.2 Análise dos dados da amostra de empresas do setor .......................................... 83

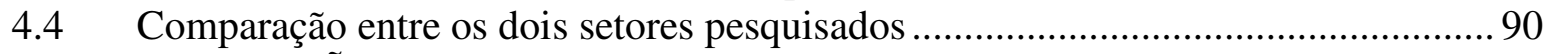

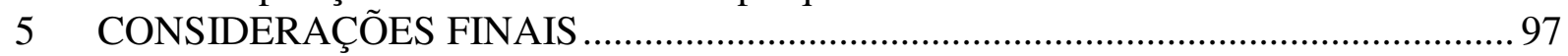

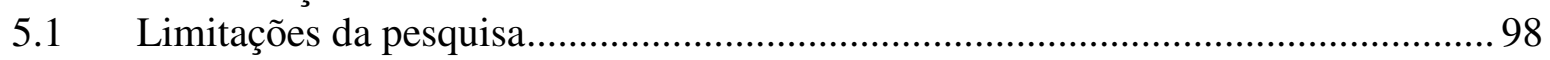

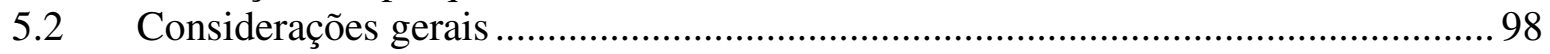

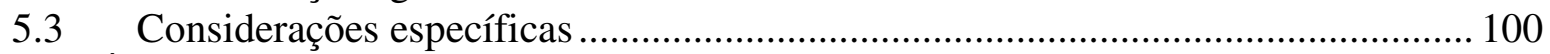

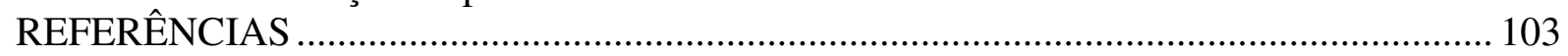

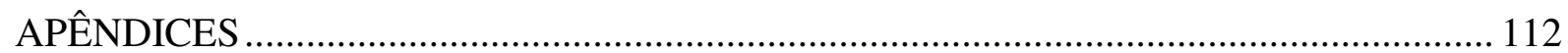




\section{LISTA DE ABREVIATURAS E SIGLAS}

ABDI: Agência Brasileira de Desenvolvimento Industrial

BACEN: Banco Central do Brasil

BMFBovespa: Bolsa de Valores de São Paulo

BP: Balanço Patrimonial

CA: Coeficientes Angulares

Capes: Coordenação de Aperfeiçoamento de Pessoal de Nível Superior

CAPM: Capital Assets Pricing Model

CDF: Custos e Despesas Fixas

CDT: Custos e Despesas Totais

CDV: Custos e Despesas Variáveis

COPOM: Comitê de Política Monetária

CPC: Comitê de Pronunciamentos Contábeis

CPV: Custo de Produtos Vendidos

CSCMP: Council of Supply Chain Management Professionals

CSN: Companhia Siderúrgica Nacional

CVM: Comissão de Valores Mobiliários

DA: Despesas de Administração

DEA: Análise por Envoltória de Dados

DRE: Demonstração de Resultado de Exercício

DV: Despesas de Vendas

EA: Efeitos Aleatórios

EBIT: Earnings Before Interest and Taxes

EF: Efeitos Fixos

EVA: Valor Econômico Agregado

GAO: Grau de Alavancagem Operacional

GEC: Gestão Estratégica de Custos

IMA: Institute of Management Accountants

IMOB: Ativo Imobilizado

IPI: Imposto sobre Produtos Industrializados

IPTU: Imposto Predial e Territorial Urbano

LNCDT: Logaritmo Neperiano de Custos e Despesas Totais

LNIMOB: Logaritmo Neperiano de Ativo Imobilizado

LNREC: Logaritmo Neperiano de Receitas Líquidas

LO: Lucro Operacional

MO: Margem Operacional

ON: Ação Ordinária

ORDOP: Outras Receitas e Despesas Operacionais

PEC: Ponto de Equilíbrio Contábil

PIB: Produto Interno Bruto

PN: Ação Preferencial

REC: Receita Líquida

RO: Rentabilidade Operacional

ROA: Return on Assets

ROE: Return on Equity

TRA: Taxa de Retorno sobre o Ativo

TRPL: Taxa de Retorno sobre o Patrimônio Líquido 


\section{LISTA DE QUADROS}

Quadro 1 - Distribuição de empresas por setor segundo a Economática ................................ 45

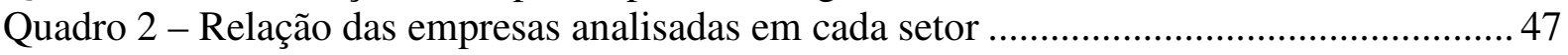

Quadro 3 - Composição dos custos e despesas totais (CDT) ............................................. 48

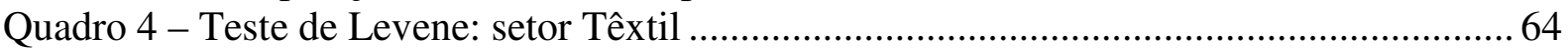

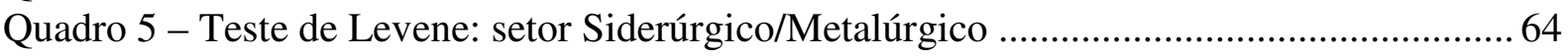

Quadro 6 - Matriz de correlação entre variáveis do modelo: Siderurgia/Metalurgia .............. 67

Quadro 7 - Correlação entre CDF com MO e CDF com RO no Têxtil (Grupos A e B) ......... 80

Quadro 8 - Relação de CDF com MO e RO no Têxtil: 2005 a 2009 ...................................... 81

Quadro 9 - Dados relativos à indústria do aço (referentes ao ano de 2009) ........................... 83

Quadro 10 - Correlação entre CDF e MO/RO na Siderurgia/Metalurgia (Grupos A e B)...... 88

Quadro 11 - Relação de CDF com MO/RO na Siderurgia/Metalurgia .................................... 89

Quadro 12 - Comparação de indicadores entre setores para empresas do Grupo A................. 91

Quadro 13 - Comparação de indicadores entre setores para empresas do Grupo B................ 92

Quadro 14 - Intervalo de CDF das empresas com MO e RO acima da média........................ 94 


\section{LISTA DE TABELAS}

Tabela 1 - Teste de redundância de efeitos fixos para o setor Têxtil ......................................56

Tabela 2 - Teste de redundância de efeitos fixos para o setor de Siderurgia/Metalurgia........ 57

Tabela 3 - Teste de Hausman para o setor Têxtil ....................................................................... 57

Tabela 4 - Teste de Hausman para o setor de Siderurgia/Metalurgia..................................... 57

Tabela 5 - Exemplo de cálculo da estrutura de custo e despesa da empresa 1 do setor Têxtil 58

Tabela 6 - Estrutura de custo e despesa das empresas do setor Têxtil ...................................59

Tabela 7 - Estrutura de custo e despesa das empresas do setor de Siderurgia/Metalurgia ...... 59

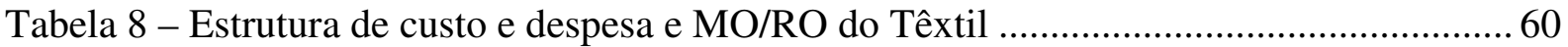

Tabela 9 - Estrutura de custo e despesa e MO/RO da Siderurgia/Metalurgia ......................... 61

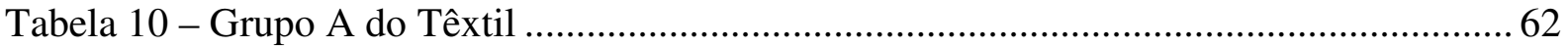

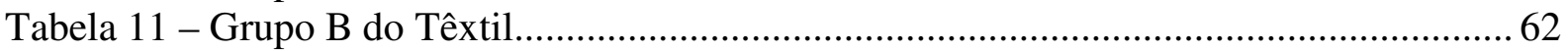

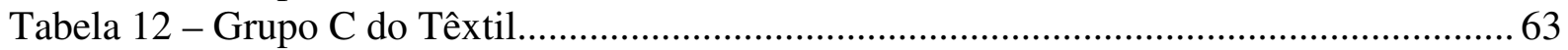

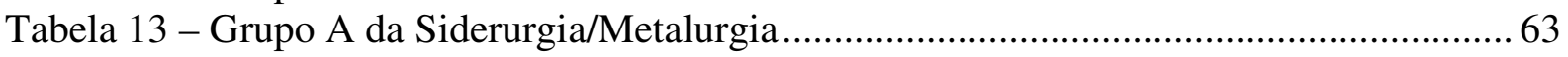

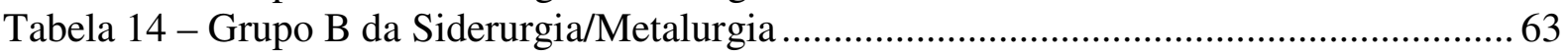

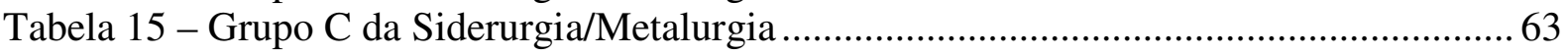

Tabela 16 - Teste de normalidade dos resíduos para o setor Têxtil ........................................66

Tabela 17 - Teste de normalidade dos resíduos para o setor de Siderurgia/Metalurgia .......... 66

Tabela 18 - Grupo C do setor Têxtil: MO e RO negativos.................................................. 75

Tabela 19 - Empresas do setor Têxtil com indicadores MO e RO positivos........................... 75

Tabela 20 - Grupo A do setor Têxtil: MO e RO acima da média........................................... 76

Tabela 21 - Grupo B do setor Têxtil: MO ou RO abaixo da média ...................................... 76

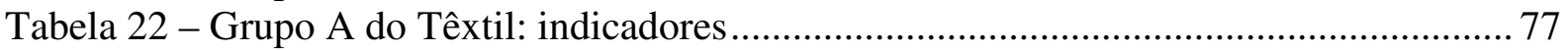

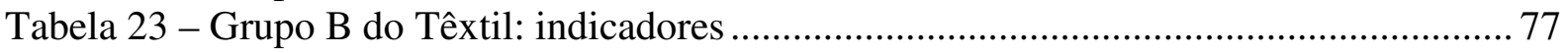

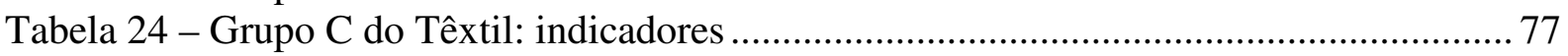

Tabela 25 - Grupo C da Siderurgia/Metalurgia: MO e RO negativos ..................................... 84

Tabela 26 - Empresas do setor Siderurgia/Metalurgia com indicadores MO e RO positivos. 84

Tabela 27 - Grupo A da Siderurgia/Metalurgia: MO e RO positivos e acima da média......... 85

Tabela 28 - Grupo B da Siderurgia/Metalurgia: MO e RO positivos, mas abaixo da média .. 85

Tabela 29 - Grupo A da Siderurgia/Metalurgia: indicadores ............................................ 85

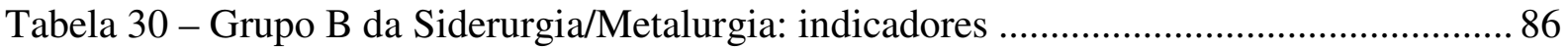

Tabela 31 - Grupo C da Siderurgia/Metalurgia: indicadores ............................................. 86 


\section{LISTA DE GRÁFICOS}

Gráfico 1 - Receitas líquidas médias das empresas do Têxtil e Selic média........................... 71

Gráfico 2 - Receitas líquidas médias das empresas da Siderurgia/Metalurgia e Selic média. 72

Gráfico 3 - Evolução do CDF médio das empresas por setor ............................................... 73

Gráfico 4 - Relação entre CDF e MO no setor Têxtil: 2005 a 2009 (Grupos A e B).............. 79

Gráfico 5 - Relação entre CDF e RO no setor Têxtil: 2005 a 2009 (Grupos A e B)............... 80

Gráfico 6 - Relação entre CDF e MO no setor Siderurgia/Metalurgia.................................... 88

Gráfico 7 - Relaçãa entre CDF e RO no setor de Siderurgia/Metalurgia .................................. 88 


\section{LISTA DE ILUSTRAÇÕES}

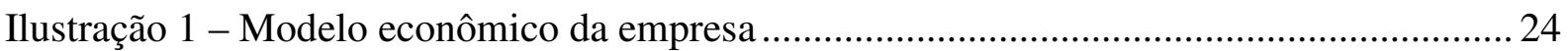

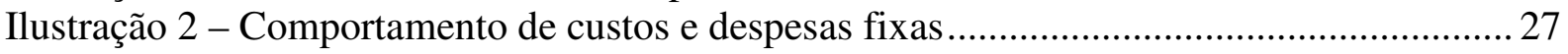

Ilustração 3 - Intervalo de CDF com MO/RO: Têxtil ............................................................. 81

Ilustração 4 - Intervalo de CDF com MO/RO: Siderurgia/Metalurgia.................................... 89

Ilustração 5 - Intervalo da composição da estrutura de custos e despesas das empresas com MO e RO positivos e acima da média. 


\section{CAMINHADA RUMO AO PROBLEMA OBJETO DO ESTUDO}

\subsection{Antecedentes}

O início da trajetória da pesquisa começou durante aulas de análise e gestão de custos em cursos de pós-graduação (Mestrado e MBA), quando vários alunos, profissionais de diversas áreas em contato com Finanças, questionaram sobre a existência de uma análise específica da composição da estrutura de custos e despesas e o relacionamento com o desempenho dos negócios. Segundo Guerreiro (2011, p. 73), a estrutura de custos fixos das empresas se assemelha a um problema de pressão.

A pressão sanguínea nos seres humanos e nos animais é uma das preocupações dos médicos e da medicina, pois, com base na sua análise, podem ser diagnosticadas várias doenças, por exemplo, a pressão alta, conhecida tecnicamente como hipertensão arterial. No caso da pressão arterial humana, o diagnóstico é baseado na sua medição com aparelho próprio, analisando-se a pressão exercida pelo coração sobre as artérias, que pode ser medida por dois valores: máximo - pressão sistólica - que diz respeito à pressão que o coração faz para bombear o sangue em direção aos outros órgãos, e o mínimo - pressão diastólica - que se refere à acomodação do sangue nos vasos sanguíneos. Para adultos, a Organização Mundial da Saúde aceita como normal uma pressão máxima de até 140 e mínima de até 90 mmHg (14 por 9).

Da analogia com as ciências médicas e com base na afirmação de Guerreiro (2011), este estudo analisou como estava a composição da estrutura de custos e despesas (fixos e variáveis) de empresas de dois setores selecionados e desenvolveu uma análise comparativa com o desempenho delas. Para se analisar a eficiência da utilização dos recursos, adotou-se a Teoria da Maximização da Riqueza dos Acionistas para identificação da criação de valor da empresa. A maximização do valor da empresa passa pela geração de lucros e rentabilidade de investimentos. Uma das variáveis de decisão dos gestores para aumentar lucros e gerar retornos é a composição da estrutura de custos e despesas. Assim, o entendimento da relação entre a estrutura de recursos e o desempenho das empresas é a base que alicerça este trabalho. 
Nesse sentido, o objetivo principal do trabalho foi estimar a estrutura de custos e despesas das empresas investigadas e identificar as organizações que obtiveram rentabilidade e lucratividade acima da média do respectivo setor no período pesquisado para verificar qual era a relação com a composição da estrutura de custos e despesas. Em pesquisas empíricas futuras, talvez se possa buscar possíveis explicações para esse fenômeno.

Pode-se dizer que esta tese conseguiu integrar conhecimentos de algumas áreas, como, Finanças (gestão do valor das empresas), Custos (identificação e análise da estrutura de custos e despesas) e Contabilidade Gerencial (mensuração e reporte do desempenho operacional econômico, financeiro e patrimonial) em uma realidade diferente (setor e tempo).

Desse estudo, foi descoberto que em cada setor existe uma faixa de estrutura de custos e despesas específica que pode ter permitido que algumas empresas tivessem melhor desempenho que outras. Isso ajuda a demonstrar que as organizações podem dispor de um mecanismo que lhes permita monitorar e detectar "hipertensão estrutural de custos e despesas", evitando que os gestores se acomodem com níveis elevados de utilização de recursos fixos que podem comprometer, silenciosamente, a rentabilidade e a lucratividade da empresa.

\subsection{Caracterização da situação problema objeto de estudo}

A situação problema deve ser caracterizada de tal forma que fique evidente a justificativa da necessidade de uma pesquisa científica para resolvê-la. Borinelli (2006, p. 09) - baseado nas considerações de Andrade (2002), Kerlinger (1980), Salomon (1999) e Theóphilo (2004) resume que um problema de pesquisa deve:

- $\quad$ Representar o ponto de partida de toda a investigação científica.

- $\quad$ Decorrer de uma questão que envolva dificuldades teóricas ou práticas.

- $\quad$ Evidenciar uma situação necessitada de discussão, investigação, decisão ou solução.

- Requerer tratamento científico.

- Estar imbuída de relevância operativa, contemporânea e humana. 
Em geral, a partir de trabalhos já realizados, deve-se procurar uma lacuna que ainda não tenha sido preenchida, tanto do ponto de vista teórico e acadêmico, como do ponto de vista prático, ou mesmo propor a integração de conceitos que até então venham sendo tratados separadamente. Este item da tese tem como objetivo principal caracterizar a situação problema objeto de estudo, demonstrando as pesquisas anteriores sobre estrutura de custos e despesas, e identificando a lacuna existente para desenvolver este estudo.

A inteligência competitiva, utilizada por algumas empresas, visa obter conhecimento do ambiente em que a organização está inserida para conseguir melhor posicioná-la estrategicamente em relação a seus concorrentes. O Institute of Management Accountants IMA (1996, p. 3) adverte que um sistema de inteligência competitiva não é sinônimo de espionagem, definindo-o como "[...] um processo de adquirir e analisar informações sobre os concorrentes, que estão disponíveis publicamente."

Dessa forma, um dos objetivos de um sistema de inteligência competitiva é analisar o comportamento dos custos e despesas dos concorrentes para comparar com os da própria organização, obtendo subsídios para a adequação de sua estrutura de utilização de recursos. Gerenciar custos e despesas é importante, pois eles, junto com as receitas, são responsáveis pela formação dos lucros, situando-se no âmago de muitas decisões empresariais (SAMUELSON; NORDHAUS, 1993, p. 138).

Martins e Rocha (2010, p. 1-3) discorrem sobre a aplicabilidade das informações de custos na contabilidade, sob as perspectivas da Contabilidade Financeira e Gerencial. Sobre Contabilidade Gerencial, que é o foco principal desta tese, os autores destacam utilidades, por exemplo: gestão de produtos, processos e pessoas; gerenciamento de preços; terceirização de atividades e avaliação da viabilidade econômica de projetos.

Um exemplo de decisão empresarial que impactou na mudança da composição da estrutura de custos e despesas ocorreu, em dezembro de 2008, com a Companhia Siderúrgica Nacional (CSN). A empresa mudou a forma de contratar os serviços de movimentação interna de insumos na Usina de Volta Redonda, no estado do Rio de Janeiro, que, até então, previa um modelo "em prateleira", no qual os recursos ficavam disponíveis em tempo integral, mesmo quando não utilizados, e começou a ser substituído por outro modelo que tem uma parte de custo fixo (tempo integral) e outra de custo variável (com base na utilização) (VALOR ON 
LINE, 2008). Dessa forma, a empresa saiu de um custo totalmente fixo para realizar aquela atividade (movimentar insumos internamente) para uma parte variável. Nesse tipo de decisão, é necessário analisar a questão do custo da capacidade, conforme orientam Martins e Rocha (2010, p. 94-95), que a classificam em capacidade nominal, normal e prática.

Hesford (1998, p. 25) adverte que "[...] muitos profissionais de inteligência competitiva não sabem nem mesmo a estrutura de custo interna" e esse conhecimento ainda é mais afastado em relação aos recursos voltados ao overhead (MILLER; VOLLMANN, 1985). Estimar a estrutura de custos dos concorrentes e a média do próprio setor de atuação representa, portanto, uma necessidade e um desafio.

Existem poucos trabalhos científicos que auxiliam na identificação das etapas contidas em um processo que permita estimar, com confiabilidade, a composição da estrutura de custos e despesas (CASELLA, 2008; BLOCHER et al, 2010), sobre correlação de custos fixos e resultados (SANTOS, 2002) ou sobre decisões de abertura de unidades ou terceirização de serviços (CHUCK et al, 2005; ARISOY et al, 2006).

Algumas pesquisas tentam analisar como as empresas avaliam os custos de concorrentes, tanto na forma de obtenção de dados, quanto na criação de um modelo conceitual, tentando obter um panorama para benchmarking na gestão estratégica de custos (FIFER, 1989; GHOSHAL; WESTNEY, 1991; WILSON, 1994; IMA, 1996; SORO, 2006; HANSEN, 1998; HESFORD, 1998; BALDUÍNO, 2003; BOSCOV; ROCHA, 2004; GOLDSTEIN, 2004; CHUCK et al, 2005; MILANI et al, 2007; SANTOS, 2010).

Essas pesquisas remetem a um desafio ainda maior, que é estimar a composição da estrutura de custos e despesas das empresas que tiveram rentabilidade e lucratividade operacional acima da média das outras empresas dentro de um mesmo setor, descrevendo uma realidade observada. Nesta tese optou-se pelo caminho de enfrentar tal desafio com informações contábeis disponíveis publicamente. Os dados contábeis necessários para operacionalização da pesquisa foram obtidos na base de dados Economática.

Para estimar e comparar a composição da estrutura de custos e despesas entre empresas é necessário haver alguma homogeneidade entre elas; portanto, decidiu-se agrupar as empresas de um determinado setor econômico e, para ampliar a discussão, após revisão da banca 
qualificadora, decidiu-se realizar o estudo para dois setores econômicos, para que pudesse ser desenvolvida uma análise comparativa dos achados. Os setores que apresentaram maior quantidade de dados completos foram o Têxtil e o Siderúrgico/Metalúrgico.

Dessa forma, a situação apresentada despertou uma inquietação que resultou na formulação da seguinte questão de pesquisa:

Qual foi a composição da estrutura de custos e despesas de empresas dos setores Têxtil e Siderúrgico/Metalúrgico, no período de 2005 a 2009, que tiveram rentabilidade e lucratividade operacional acima da média?

\subsection{Objetivos da pesquisa}

De acordo com a situação problema identificada e com a questão de pesquisa levantada, os objetivos estabelecidos são:

a) Objetivo 1: estimar a composição da estrutura de custos e despesas média das empresas dos dois setores selecionados, em termos de fixos e variáveis, a partir de aplicação de uma metodologia econométrica, com utilização de dados públicos.

b) Objetivo 2: relacionar a composição levantada no objetivo 1 com a rentabilidade e lucratividade operacional, para que se possa estimar o intervalo de estrutura de custos e despesas em que empresas com diferentes níveis de desempenho operaram durante o período estudado.

c) Objetivo 3: identificar a composição da estrutura de custos e despesas das empresas que tiveram rentabilidade e lucratividade operacional negativa, acima da média e abaixo da média. 


\subsection{Justificativas e contribuições do estudo}

O entendimento e o gerenciamento dos custos e despesas das organizações são importantes tanto na visão dos profissionais de mercado como na dos acadêmicos. Uma pesquisa realizada por Foster e Young (1997), com 300 (trezentos) gerentes gerais e de contabilidade na Austrália, identificou que os assuntos de gerenciamento de custos e controle de custos foram citados entre os mais importantes, tanto nos anos 1980, quanto na época da pesquisa.

Pesquisas demonstram que as organizações devem se preocupar com sua estrutura de custos e despesas, principalmente quando existem mudanças no comportamento de seus recursos, por exemplo, quando as empresas passam de uma composição mais intensa de custos variáveis e diretos para outra de custos fixos e indiretos (MILLER; VOLLMANN, 1985; BRIMSON, 1996; SAKURAI, 1997; GUERREIRO, 2011).

As tecnologias modernas empregadas nos processos de produção de bens e serviços têm impactado a estrutura de custos e despesas das empresas, tais como o grau de automação dos processos, empresas de robôs, controles eletrônicos, incorporação progressiva de sistemas de informação e outros, tornando-a composta predominantemente por recursos fixos (GUERREIRO, 2011, p. 58). Dessa forma, devido às mudanças mencionadas, faz-se necessário um maior entendimento da estrutura de custos e despesas das organizações, o que abre uma oportunidade para esta pesquisa de entendimento da realidade de organizações brasileiras.

Adicionalmente, considerando-se uma visão estratégica, contemplando todos os recursos disponíveis da organização, as alternativas de ações além das fronteiras da organização podem ser tão ou mais importantes que o conhecimento do seu próprio custo, influenciando até na definição do seu posicionamento estratégico. Dessa forma, é interessante que se compreenda a estrutura de custos e despesas das empresas do seu setor de atuação, da cadeia de valor e dos concorrentes.

Importantes decisões podem ser tomadas quando do conhecimento dos custos e despesas fora do âmbito da própria organização; porém, poucas organizações fazem desse procedimento uma rotina dentro da sua inteligência competitiva, principalmente devido às organizações 
terem dificuldades de acesso a tais informações, respeitando os princípios éticos (SUBRAMANIAN; ISHAK, 1998; BALDUÍNO, 2003, p. 56; MILANI et al, 2007).

Hesford (1998) investigou o tipo de informação utilizada por profissionais de inteligência competitiva dos Estados Unidos e Canadá e constatou que esses profissionais não consideram estimar os custos dos concorrentes por acreditarem que existe um alto grau de complexidade nessa tarefa, tornando o processo de obtenção de tal informação muito custoso.

Para reforçar essa constatação, segundo pesquisa realizada no Brasil por Milani et al (2007), replicando a de Subramanian e Ishak (1998) realizada com empresas norte-americanas, algumas informações sobre custos dos concorrentes, apesar de serem consideradas relevantes, não são coletadas, por serem consideradas de difícil acesso, por exemplo: custo por produto, estratégia de propaganda e custo de produção total (MILANI et al, 2007, p. 24-25).

Casella (2008) propôs uma metodologia de análise de custo de concorrentes baseada nas demonstrações financeiras de quatro empresas brasileiras do setor de papel e celulose. Dentre as técnicas utilizadas para se estimar a estrutura de custo dessas empresas, a autora selecionou a análise de regressão simples; no entanto, para duas empresas da amostra ocorreram problemas para se estimar os custos fixos devido à falta de significância estatística do intercepto do modelo.

Este estudo, por sua vez, pretende gerar um panorama de estrutura de custos e despesas por setor de atuação, fornecendo uma metodologia de cálculo que possa ser utilizada para análise da estrutura de custos e despesas de diversos setores, de concorrentes, clientes e fornecedores, no caso em que a empresa não tenha acesso direto a fontes de informação internas. Diferente do trabalho de Casella (2008), esta tese busca estimar a estrutura de custo e despesa de empresas brasileiras de setores específicos (Têxtil e Siderurgia/Metalurgia) com utilização da análise de regressão com dados em painel. Trata-se de uma técnica econométrica para controlar variáveis não observadas e que trabalha com duas dimensões, uma espacial (crosssections) e outra temporal (STOCK; WATSON, 2004; GUJARATI, 2006).

Burdisso (1997) defende que essa técnica é adequada para o propósito de estimar uma função de custo de um grupo de empresas porque melhora a estimação dos parâmetros, uma vez que controla a heterogeneidade individual das empresas ao longo do tempo. A autora explica que 
nem todas as organizações tomam suas decisões da mesma forma, mas que seus modelos de decisão não costumam variar por determinado intervalo de tempo; por isso, a técnica se mostra adequada.

Guilding (1999, p. 584) alertou para a carência na literatura contábil de tentativas de sínteses de práticas de análise de custo de concorrentes. Rodrigo Santos (2010) contribuiu para a pesquisa nesse campo ao organizar o arcabouço teórico sobre análise de custo de concorrentes; no entanto, sua pesquisa adotou uma abordagem de análise qualitativa. Esta tese pretende contribuir apresentando uma abordagem quantitativa e qualitativa da análise de custos, a partir da estimação da estrutura de custo de empresas de setores específicos.

A análise dos custos dos concorrentes é importante não apenas para que a empresa possa monitorar os movimentos de seus concorrentes, mas também para que se possa obter um benchmarking que ajude a organização dos custos futuros (HEINEN; HOFFJAN, 2005, p. 18). Dessa forma, cabe reforçar que a técnica apresentada nesta tese permite estimar a estrutura de custos e despesas do setor para auxílio no benchmarking das empresas, permitindo às organizações um monitoramento quanto à "hipertensão estrutural de custos e despesas", evitando que os gestores se acomodem com níveis elevados de utilização de recursos fixos que podem comprometer, silenciosamente, a rentabilidade e a lucratividade da empresa.

Para a academia, esta tese é importante para ajudar a preencher a carência na literatura contábil de estudos que sintetizem técnicas de análise de custos de concorrentes, conforme Guilding (1999). Para as organizações, é uma oportunidade de adicionar essa ferramenta às suas práticas de gestão, especialmente na área de inteligência competitiva.

O produto final deste trabalho está materializado em uma análise contendo a estrutura de custos e despesas das empresas dos dois setores selecionados, segregando as empresas em três grupos distintos: (a) empresas com indicadores de lucratividade e rentabilidade acima da média; (b) empresas com aqueles indicadores abaixo da média; e (c) empresas com os indicadores negativos. Essa análise deve prover informações importantes para servir como métrica de desempenho quando comparado com a própria empresa e pode incentivar decisões tanto na prática empresarial quanto na pesquisa acadêmica. 
Cabe aos pesquisadores da área de Controladoria e Contabilidade Gerencial se aprofundar na questão, para identificar o que pode estar afetando a eficiência, a qualidade e a competitividade da estrutura de custos e despesas de cada setor, analisando como os determinantes de custos - tecnologia, escala, nível de utilização de capacidade, complexidade, curva de experiência, entre outros - impactam na estrutura de custos e despesas, alcançando novos conhecimentos. Além disso, os pesquisadores poderão replicar a técnica em outros setores ou períodos, e poderão fazer comparações com este estudo.

Cabe aos profissionais de mercado, principalmente os responsáveis por decisões estratégicas nas empresas, analisar a situação atual da empresa e comparar com o desempenho descrito no painel fornecido por esta tese para influenciar na estratégia que a empresa está tomando e tentar melhorar o desempenho da rentabilidade e lucratividade operacional, com o objetivo de maximizar o valor da empresa. Além disso, profissionais de outros setores não pesquisados por esta tese podem levantar as informações das empresas do seu setor de atuação para identificar o cenário na sua realidade.

\subsection{Delimitações do estudo: conceitual, temporal, setorial, geográfica e de foco}

\subsubsection{Delimitação conceitual}

Como delimitação conceitual, este estudo está inserido no contexto da Teoria da Maximização do Valor da Empresa, pois visa fornecer subsídios às decisões dos gestores no sentido de maximizar o valor da empresa. Dentre os vários caminhos possíveis para cumprir a maximização do valor, destaca-se, neste trabalho, a gestão da estrutura de custos e despesas das organizações, caracterizando e analisando suas dimensões dentro de um enfoque de correlação entre a estrutura de custos e despesas e o retorno e o lucro operacional.

\subsubsection{Delimitação temporal}

Quanto ao espaço temporal, considerou-se um horizonte de cinco anos completos. O desenvolvimento da pesquisa foi realizado em 2010 e 2011, portanto o corte foi realizado no período imediatamente anterior ao do início dos trabalhos. Dessa forma, o período de análise foi de 2005 a 2009. Este horizonte foi considerado, pelo pesquisador e pela banca avaliadora 
no exame de qualificação, como sendo suficiente para capturar mudanças nos níveis de atividade das empresas e que podem afetar os custos e despesas fixas (CDF), tanto operacionais quanto estruturais (Martins e Rocha, 2010).

\subsubsection{Delimitação setorial}

Quanto à delimitação do setor econômico, pela credibilidade necessária requerida para o estudo a ser desenvolvido, este trabalho concentrou-se nas grandes organizações listadas na Bolsa de Valores de São Paulo (BMFBovespa). Empresas de capital aberto devidamente inscritas na Comissão de Valores Mobiliários (CVM), com demonstrações contábeis publicadas e auditadas. Dentre os setores pesquisados, selecionaram-se aqueles com maior quantidade de empresas com dados completos para o período de análise. Assim, foram selecionados dois setores (separados de acordo com a classificação proposta pela Economática): (a) Têxtil; e (b) Siderurgia/Metalurgia.

\subsubsection{Delimitação geográfica}

Utilizou-se como base de dados a fonte da Economática que contém informações das empresas listadas nas bolsas dos EUA, Brasil, Argentina, Chile, México, Peru, Colômbia e Venezuela, além de fornecer número das demonstrações contábeis, indicadores e informações do mercado financeiro. $\mathrm{O}$ objeto de estudo deste trabalho são as informações que estão nas demonstrações contábeis de empresas que atuam no Brasil e que estavam dentro da base de dados da Economática.

\subsubsection{Delimitação de foco}

O objetivo da tese é identificar e procurar o relacionamento da estrutura de custos e despesas com o desempenho econômico, em relação apenas a duas variáveis: lucratividade e rentabilidade. Não foi objetivo do trabalho discutir questões relacionadas a modelos de negócios, direcionadores de custos e resultados específicos para cada setor, comportamento esperado das empresas nos momentos de expansão e retração de atividade, explicação de recursos utilizados pelas organizações, entre outros pontos.

Apesar de não ter sido objetivo do estudo, por sugestão da banca de qualificação a título de complementaridade, no Capítulo 4 é desenvolvido uma breve discussão das características 
típicas de cada setor para auxílio complementar na interpretação dos dados e, depois, é realizada uma comparação dos resultados entre os dois setores estudados. Também se julgou propícia a análise do contexto econômico do período de 2005 à 2009 para ajudar a compreender possíveis mudanças no padrão de desempenho das empresas nos setores pesquisados. Tal análise foi baseada no panorama descrito pelo Relatório Anual do Boletim Banco Central do Brasil, disponível no website dessa instituição.

\subsection{Organização do trabalho}

O Capítulo 1 descreve a caminhada rumo ao problema de investigação, como surgiu a ideia, a caracterização da situação problema objeto de estudo, os objetivos a serem alcançados ao final do trabalho, as justificativas deste estudo, a delimitação conceitual, temporal, setorial, geográfica e de foco, por fim, a organização do trabalho que será entregue ao leitor.

No Capítulo 2 é apresentado o referencial teórico necessário para a compreensão do estudo teoria da maximização do valor da firma, as definições dos conceitos sobre a estrutura de custos e despesas, desempenho econômico, lucratividade e rentabilidade - e as principais variáveis que são utilizadas no modelo de análise desta pesquisa.

No Capítulo 3 é demonstrada a trajetória metodológica. O delineamento, o tipo de pesquisa e os instrumentos de coleta de dados são apresentados e discutidos, finalizando com uma discussão acerca das análises necessárias para atingir os objetivos deste estudo e as limitações encontradas.

No Capítulo 4 são apresentados os resultados e a análise da pesquisa realizada. Comentam-se os dados e informações obtidas e analisam-se as relações com a teoria fundamentada no referencial teórico.

No Capítulo 5, encontram-se as considerações finais, fornecendo-se, a partir dos resultados desta tese, as conclusões, as limitações e as sugestões para pesquisas futuras. 


\subsection{Formatação, referências bibliográficas e citações}

Neste trabalho estão observados, para alcançar o atendimento aos requisitos de uma publicação acadêmica, a formatação, as referências bibliográficas, as citações e outros itens necessários à correta elaboração, de acordo com o Manual para Formatação e Edição de Dissertações e Teses (MARTINS, Gilberto et al, 2004), documento eletrônico obtido no site da Faculdade de Economia, Administração e Contabilidade da Universidade de São Paulo. 


\section{REFERENCIAL TEÓRICO}

Este capítulo é dedicado a tratar dos principais conceitos que norteiam e delimitam este estudo, que está dentro do campo da Gestão Estratégica de Custos. Essas informações devem orientar a trajetória da pesquisa, subsidiar a análise dos resultados e ajudar no cumprimento dos objetivos da pesquisa.

Abordam-se aspectos fundamentais da Gestão Estratégica de Custos, Teoria do Crescimento da Firma, da Teoria da Maximização do Valor da Empresa e da Teoria do Equilíbrio de Interesse dos Stakeholders, as quais representam a plataforma teórica que fornece apoio às ideias e aos argumentos defendidos nesta tese. São abordados também os conceitos fundamentais de custos e despesas, bem como a taxonomia desses recursos relacionada à natureza do seu comportamento, ou seja, custos e despesas variáveis (CDV) e custos e despesas fixas (CDF).

Sobre o desempenho econômico das organizações, neste capítulo são abordados e discutidos os indicadores econômicos utilizados nesta tese - Retorno Operacional (RO) e Margem Operacional (MO) - que são utilizados para análises de demonstrações financeiras públicas. Por fim, é explicado o motivo da não utilização de outras métricas de desempenho que já foram utilizadas em outras pesquisas, mas não foram para esta tese.

\subsection{Gestão Estratégica de Custos}

A Gestão Estratégica de Custos (GEC) para Anderson (2006, p.2) tem o objetivo de alinhar a estrutura de custos e despesas da empresa para otimizar o seu desempenho, conforme sua estratégia. $\mathrm{O}$ autor complementa dizendo que a gestão dos custos é apenas uma parte do complexo desafio de maximizar lucros no longo prazo.

Shank (1989, p. 355) comenta que a GEC é um desdobramento do tema Contabilidade Estratégica, com origem na década de 1980, a partir do trabalho de Simmonds (1981). Anderson (2006, p. 5) complementa dizendo que as pesquisas nessa área, inicialmente, foram 
bastante incentivadas pelos trabalhos de Porter (1980, 1985), que mostravam como as empresas deveriam avaliar suas condições competitivas para desenvolver estratégias.

Cabe ressaltar que Porter $(1980,1985)$ representa apenas uma das abordagens: posicionamento estratégico. Na dissertação de Santos (2010) são demonstradas algumas outras visões, como, por exemplo: a tipologia estratégica (MILES; SNOW, 1978), missão estratégica (HOFER; SCHENDEL, 1978; GRUPTA; GOVIDARAJAN, 1984) e visão baseada em recursos (BARNEY, 1991; GRANT, 1991, 1992).

O surgimento da Contabilidade Estratégica foi, portanto, uma resposta às demandas das empresas por uma visão integrada dos problemas organizacionais. Problemas de produção, de vendas e de logística deveriam ser tratados como problemas da organização (e não como questões isoladas) e as possíveis soluções deveriam considerar o caráter integrado dessas funções e, ainda, estar alinhadas à estratégia global da organização, passando a ter o importante papel de facilitar a formulação e implantação das estratégias organizacionais (SHANK, 1989, p. 356).

Para responder a essas demandas, a GEC desenvolveu diversas frentes de pesquisa, como, por exemplo: análise da cadeia de valor, Gestão de Custos Interorganizacionais, análise do posicionamento estratégico da empresa, análise dos determinantes e direcionadores de custos, gestão de overhead, análise de custo de concorrentes; custeio alvo; custo total de propriedade, custeio por ciclo de vida e custo da qualidade (MILLER; VOLLMANN, 1985; SHANK; GOVINDARAJAN, 1993; COOPER; SLAGMULDER, 2003a; SHANK, 1989).

Dentre esses diversos campos de pesquisa, este trabalho foca a análise da composição da estrutura de custos e despesas das empresas que tiveram desempenho econômico acima da média dos setores pesquisados, gerando um cenário dos setores selecionados. Portanto, podese afirmar que as contribuições fornecidas por esta tese estão no campo de estudo da GEC, pois podem fornecer informações para auxiliar no processo de decisão estratégica, auxiliando a escolha de uma ferramenta apropriada para melhorar o desempenho organizacional, em busca do aumento do valor das organizações. 


\subsection{A busca do valor da firma}

O clássico trabalho de Penrose (1959) descreve "a Teoria do Crescimento da Firma". Nessa obra, a autora explica que o crescimento organizacional é apenas uma parte do processo que gera valor nas entidades. Para a autora, do ponto de vista econômico, a motivação para esse crescimento é a geração de dinheiro; assim, os lucros seriam desejados para o próprio proveito da firma e para gerar ainda mais lucros (PENROSE, 2006, p. 68). No entanto, a autora também reconhece que existem 'outros objetivos' para a firma.

Esses outros objetivos são contemplados na Teoria do Equilíbrio de Interesse dos Stakeholders, quando defende que as decisões dos gestores das organizações devem ser tomadas para equilibrar e satisfazer aos interesses de todos os públicos envolvidos com a corporação (SILVEIRA et al, 2005, p. 35).

Essa defesa de múltiplas funções objetivo pregada pela Teoria dos Stakeholders é criticada por Jensen (2000, p. 6), que afirma ser impossível maximizar os valores em diversas dimensões. Segundo o autor, os stakeholders possuem interesses conflitantes e, ao tentar atender a todos, a organização incorre no risco de não ter objetivo específico.

Diante dessas alternativas, para se analisar a eficiência da utilização dos recursos pelas entidades no processo de obtenção de lucro, nesta tese optou-se por adotar uma perspectiva única, a visão dos acionistas, na criação de valor da empresa, indo de acordo com a Teoria da Maximização da Riqueza dos Acionistas (Teoria dos Shareholders) que prega que os gestores devem ser orientados a tomar suas decisões no sentido de maximizar o valor total da empresa (JENSEN, 2000, p. 1). Assim, o entendimento da relação que existe entre a estrutura de recursos utilizados e o retorno do investimento dos acionistas deve ser buscado pelos gestores.

Brealey et al (2003, p. 18-19) concordam com essa visão e complementam afirmando que os gestores são profissionais escolhidos pelos acionistas para tomar decisões que possam maximizar o valor da empresa e, consequentemente, maximizar a riqueza dos próprios acionistas. Ross et al (2008, p. 8) listam alguns objetivos possíveis para os gestores, orientados à maximização do valor da empresa: 
- $\quad$ Sobreviver.

- Evitar problemas financeiros e falência.

- Superar a concorrência.

- Maximizar as vendas ou a participação de mercado.

- Minimizar os custos.

- Maximizar os lucros.

- Manter o crescimento constante dos lucros.

\subsection{Custos e Despesas Totais (CDT)}

Não é o propósito desta pesquisa a discussão conceitual de custos e despesas ${ }^{1}$. Resumidamente, pode-se dizer que ambos representam sacrifícios com propósito de gerar receitas (recursos consumidos, utilizados ou transformados) e que o conceito de custo está relacionado com o processo de produção e o de despesa dentro de outros processos, como, por exemplo, nos processos de administração e de comercialização.

Para este trabalho, investigou-se a relação de consumo de recurso provocado tanto pelo volume de produção quanto aquele resultante da capacidade instalada da empresa, separando em parte fixa e variável.

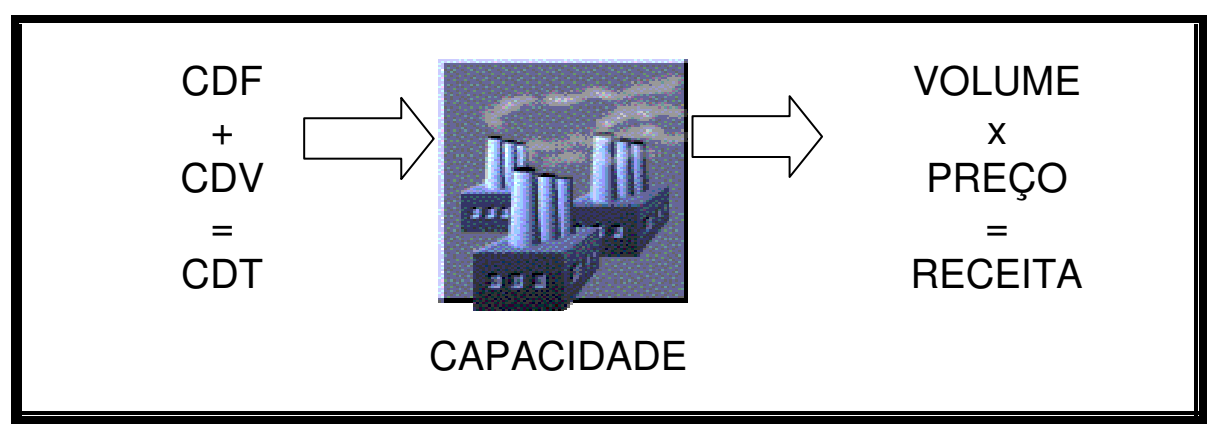

Ilustração 1 - Modelo econômico da empresa FONTE: adaptado de Guerreiro (2011, p. 53)

Utiliza-se a terminologia custos e despesas totais em conjunto (CDT) - para a parte fixa: custo e despesa fixa $(\mathrm{CDF})$ e para a parte variável: custo e despesa variável (CDV) - como a

\footnotetext{
${ }^{1}$ Para maiores detalhes sobre a diferença entre custo e despesa, consultar o livro MARTINS, Eliseu; ROCHA, Welington. Métodos de custeio comparados: custos e margens analisados sob diferentes perspectivas. São Paulo: Atlas, 2010.
} 
expressão monetária do consumo, da utilização ou da transformação de recursos com objetivo de gerar e comercializar produtos, sejam eles bens ou serviços (GUERREIRO, 2011. p. 58; MARTINS; ROCHA, 2010, p. 8).

No modelo econométrico que será abordado no Capítulo 3 deste trabalho, a soma dos custos e das despesas totais (CDT) extraídos das demonstrações financeiras publicadas representa a variável dependente, enquanto que a receita líquida e o ativo imobilizado serão variáveis explicativas. Essas duas variáveis (receita líquida e ativo imobilizado) foram utilizadas como proxies para representar o volume de produção e a capacidade instalada. A partir dessas variáveis pretende-se estimar a parcela de custo e despesa fixa e variável contida nos CDT.

\subsubsection{Custos e Despesas Variáveis (CDV)}

A diferença entre custo e despesa é que o primeiro representa a expressão monetária do consumo, utilização ou transformação de recursos no processo de produção de bens ou serviços, enquanto que o segundo representa a expressão monetária do consumo, utilização ou transformação de recursos no processo de administração geral da organização e demais processos que ocorrem após a produção dos bens e serviços (MARTINS; ROCHA, 2010, p. 9-17).

Segundo Martins e Rocha (2010, p. 25), os “[...] custos variáveis são aqueles cujo montante é afetado de maneira direta pelo volume, dentro de determinado intervalo de nível de atividade." Os autores explicam também que existem despesas variáveis de vendas, tais como comissão dos vendedores, royalties etc., que também são influenciadas pelo volume de produção.

A medida de atividade é, geralmente, a quantidade de bens e serviços destinados aos clientes externos, que gera receita para a empresa, como, por exemplo: unidades ou toneladas produzidas (manufatura), clientes atendidos (certos tipos de serviços), carga ou passageiros transportados (empresa de transporte), minutos de ligação (telecomunicações), materiais e medicamentos (hospitais) e transações realizadas (bancos).

Blocher et al (2010) também relacionam o conceito de custo variável ao volume de direcionador de custo. Segundo esses autores, "[...] custo variável é a mudança no custo total 
associada à mudança na quantidade de direcionador de custos”,2 (BLOCHER et al, 2002, p. 68). Esta definição representa uma abordagem microeconômica baseada no gráfico da função de custo total.

Encontra-se ainda em Guerreiro (2011, p. 58) que os custos e despesas variáveis possuem características específicas: (1) variam em função do volume de produção e vendas; (2) são identificados objetivamente com a unidade de produto e (3) são expressos em valores unitários.

Martins e Rocha (2010, p. 25) citam como exemplos de custos e despesas variáveis: matériaprima, outros insumos variáveis, energia elétrica consumida no processo de produção ou na prestação do serviço, ferramentas de curta duração e materiais auxiliares, comissão de vendedores, fretes sobre vendas, embalagens de entregas. No entanto, os autores advertem que é difícil mencionar com certeza absoluta exemplos de custos e despesas variáveis, pois tal classificação depende do tipo de indústria e das circunstâncias de aquisição e de utilização dos recursos.

\subsubsection{Custos e Despesas Fixas (CDF)}

"Os custos fixos são os recursos consumidos, utilizados ou transformados que não são afetados pelo volume, dentro de determinado intervalo do nível de atividade" (MARTINS; ROCHA, 2010, p. 21). De maneira análoga, as despesas fixas são expressões monetárias do consumo de recursos no processo de administração da organização e demais processos que ocorrem antes e após a produção de bens e serviços, que não são afetadas pelo volume de produção, dentro de determinado intervalo do nível de atividade.

Assim, os custos e despesas fixas (CDF) representam consumo de recursos não relacionados diretamente com a produção de uma unidade de produto; no entanto, são necessários para a manutenção do sistema produtivo.

Segundo Guerreiro (2011, p. 52), “[...] os recursos fixos estão relacionados diretamente com a capacidade instalada da empresa”, são sua estrutura. Esses recursos podem ser identificados

\footnotetext{
2 "Variable cost is the change in the total cost associated with each change in the quantity of the cost driver."
} 
com diferentes objetos, exceto a unidade de produto, e se expressam natural e automaticamente a partir de valores totais relacionados ao período de tempo. Deve ser observado que a ocorrência dessa natureza de recurso depende fundamentalmente de decisões do passado.

Existem, contudo, certas categorias de $\mathrm{CDF}$ que podem sofrer variações à medida que a organização necessita readequar a sua capacidade produtiva. Para VanDerbeck e Nagy (2003, p. 444), esse tipo de custos e despesas fixas "[...] tendem a permanecer os mesmos sobre certa amplitude de atividade, mas aumentam quando a produção excede certos limites."

Martins e Rocha (2010, p. 22-23) separam os custos e despesas fixas em dois tipos: (a) estruturais: necessários para dar sustentação e estão relacionados à capacidade máxima e (b) operacionais: necessários para a operação das instalações e não estão, necessariamente, relacionados à capacidade máxima.
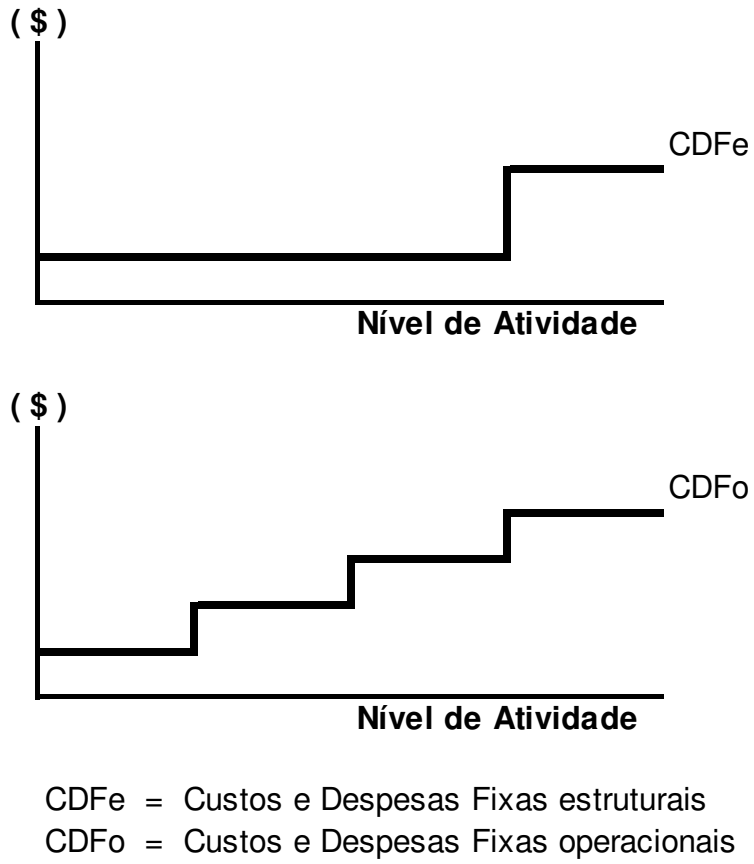

Ilustração 2 - Comportamento de custos e despesas fixas FONTE: adaptado de Martins e Rocha (2010, p. 23)

Guerreiro (2011, p. 59) identifica outras quatro características dos custos e despesas fixas: (1) são indiferentes às oscilações do volume de produção e vendas; (2) são identificados objetivamente com a estrutura da empresa; (3) são expressos em valores totais por período de tempo; e (4) dependem das decisões do passado. 


\subsubsection{Exemplo de situações baseadas na análise de CDV e CDF}

Evidências empíricas relatadas em diversos artigos (MAUER; OTT, 1995; KALLAPUR, ELDENBURG, 2005; PIZZINI, 2006; COOK et al, 2007; JENSEN; MECKLING, 1976; BRICIU; SAS, 2009) comprovam que conhecer o comportamento dos CDT é importante para o processo de tomada de decisões estratégicas, que visam à maximização do lucro das empresas. A seguir, citam-se alguns exemplos de decisões baseadas na análise da estrutura de custos e despesas (CDV e CDF):

\section{a) INCERTEZA, RISCO E LUCRATIVIDADE}

Mauer e Ott (1995) estudaram a relação entre volatilidade nos valores de custos e despesas e a influência nas decisões de investimento pelos gestores. Os autores constataram que, em situações em que há incerteza quanto ao comportamento dos custos e despesas, os gestores preferem adiar as decisões de investimento, mesmo que esse investimento possa resultar em diminuição de gastos operacionais.

Kallapur e Eldenburg (2005) constataram que a mudança no comportamento dos custos e despesas está relacionada ao nível de incerteza no setor. Segundo os autores, em ambiente com maior grau de incerteza, as empresas preferem reduzir os investimentos que geram custos e despesas fixas e, consequentemente, há maior participação dos custos e despesas variáveis na sua estrutura.

Pizzini (2006) realizou pesquisa com hospitais norte-americanos e constatou que o nível de detalhe fornecido pelos sistemas de custeio está relacionado à importância que os gestores atribuem às informações. Constatou ainda que, quanto maiores os níveis de detalhes fornecidos pelos sistemas de custo, maiores eram os indicadores de desempenho financeiro, como margem operacional.

\section{b) GERENCIAMENTO DE RESULTADOS}

Se, por um lado, a percepção de incerteza leva os gestores a praticar uma estrutura de custos e despesas com maior participação de recursos variáveis, por outro Cook et al 
(2007) constataram empiricamente que uma estrutura com maior participação de recursos fixos favorece os gestores na manipulação dos lucros por meio de administração do volume de produção. Os autores explicam que esse fenômeno ocorre porque o método de custeio por absorção faz com que o custo fixo seja incorporado ao produto; portanto, a variação do volume de produção altera o custo unitário de produtos vendidos e, consequentemente, impacta o resultado do período.

Pesquisas e a legislação em Contabilidade já estão preocupadas com essa manipulação e estão tomando medidas para minimizar o impacto discutido pelos autores. No entanto, é preciso salientar que a gestão do lucro através da manipulação do nível de produção provoca efeitos no custo de estocagem e também nos impostos sobre os lucros. Cabe aos gestores analisar os trade offs resultantes dessa decisão.

\section{c) OCIOSIDADE}

Martins e Rocha (2010, p. 98-101) criticam a abordagem de que o custeio por absorção proporciona margem para manipulação do resultado, conforme discutido pelos autores mencionados no parágrafo anterior. Eles argumentam que o nível real de produção não deveria afetar o resultado do período e explicam que as empresas deveriam alocar os custos fixos aos produtos a uma taxa baseada no volume normal, esperado; sendo assim, o custo da ociosidade real deveria ser alocado diretamente ao resultado do período e não ao custo do produto. Os autores argumentam ainda que a decisão de estabelecer um volume de produção acima da previsão da demanda não deveria prosperar, pois cria um estoque desnecessário.

\section{d) FORMALIZAÇÃO DE CONTRATOS}

Lopes e Martins (2005, p. 32) explicam que a firma - do ponto de vista microeconômico - é vista como um conjunto de contratos, e o estabelecimento de um equilíbrio entre os contratos é o que define o funcionamento adequado entre os agentes. É importante destacar que qualquer atividade, geradora de custos e despesas, pode ser desempenhada tanto internamente pela empresa quanto por terceiros. No entanto, o que define a natureza do comportamento dos recursos (se fixos ou variáveis) é o contrato estabelecido entre os agentes envolvidos. 
Dessa forma, o mercado pode ser visto como um conglomerado de contratos firmados entre agentes econômicos (acionistas, empregados, fornecedores, clientes, governo etc.) e as relações entre eles são regidas por contratos bilaterais que, teoricamente, podem ser firmados e rompidos a qualquer momento (JENSEN; MECKLING, 1976, p. 306).

Martins e Rocha (2010, p. 27-29) explicam que são os contratos que definem a natureza do custo ou despesa. Os autores citam o exemplo de custo de mão de obra direta que, dependendo do tipo de contrato, pode ser classificado como custo totalmente fixo, totalmente variável ou mesmo um custo híbrido.

\section{e) PREVISIBILIDADE}

A análise e o controle de custos e despesas envolvem o conhecimento e entendimento das características das atividades desenvolvidas pela empresa, bem como dos relacionamentos com o ambiente externo (BRICIU; SAS, 2009, p. 272) ${ }^{3}$. Segundo os autores, em cenários de crise, as empresas tendem a aumentar o controle; porém, quando o cenário futuro é favorável, elas desenvolvem estratégias de crescimento de investimentos, modernização de instalações e aumento da capacidade. Portanto, a análise do cenário futuro, juntamente com a estratégia, influencia a estrutura de custos.

Quando o cenário é favorável para a empresa há incentivos para realização de novos investimentos e aumento de capacidade e, previsivelmente, acontece aumento de custos e despesas fixas. Em decorrência desse cenário, há maior previsibilidade de utilização de recursos, considerando que existe um orçamento que seja utilizado como um instrumento de controle para o alcance do resultado planejado (FREZATTI, 2000, p.36).

Quando a predominância é de recursos variáveis, o consumo dos recursos fica mais dependente da demanda. Para aumentar a previsibilidade do comportamento dos custos e despesas, nesse cenário, é preciso desenvolver sistema eficaz de previsão da demanda. O Council of Supply Chain Management Professionals (CSCMP, 2010) desenvolveu um

\footnotetext{
3 "Cost analysis and control involve the awareness and understanding of the general characteristics of the activity carried out by the entity, but also the understanding of the interdependent relationship existing between the entity and the (economic, political, technological, social etc.) environment where activity is actually carried out."
} 
guia de práticas recomendadas para cadeias de suprimento, em que são fornecidas instruções para melhorar as práticas de previsão e gestão da demanda. Dentre as ações recomendadas pelo guia estão: atribuir a responsabilidade de previsão da demanda para um gestor específico; aumentar o nível de colaboração entre parceiros com base no compartilhamento de informações de estoque; realização de reuniões semanais entre parceiros para discutir as previsões de curto prazo; zelar pela consistência entre o orçamento financeiro, as previsões e o plano operacional etc.

\section{f) ANÁLISE DE CENÁRIOS}

A segregação entre custos e despesas fixos e variáveis é importante para avaliação de desempenho da empresa e dos gestores, e a ferramenta que muitas companhias utilizam para essa finalidade é o orçamento flexível (HILTON, 2008, p. 458). Hilton (2008, p. 464) explica que o objetivo do orçamento flexível é simular cenários de produção de uma empresa para que o gestor possa decidir a melhor opção, baseando sua decisão nas informações de custos e despesas variáveis e fixas.

Assim, com base nessa ferramenta é possível que as empresas consigam analisar as variações de custos e despesas realizadas e planejadas, segregando as explicações por tipos de influência, como, por exemplo, apurando as variações de eficiência (quantidade de recurso consumido), de preço e de moedas.

Além dos exemplos das evidências empíricas de diversos artigos, a segregação entre CDF e CDV é útil para as outras finalidades, que podem ser encontradas em Martins e Rocha (2010, p. 31):

a) Planejamento operacional. Simular variações no custo total da empresa, dadas as determinações no nível de atividade.

b) Mensuração do risco operacional. É o perfil da estrutura de custos, medido pela proporção dos custos fixos e dos variáveis em relação ao custo total e reflete o nível de risco operacional. No modelo Capital Assets Pricing Model (CAPM), de valoração de ativos, o risco operacional afeta o valor do fator beta e, consequentemente, o valor da empresa. 
c) No mesmo sentido da alínea anterior, calculando-se a proporção de custos fixos em relação ao valor adicionado.

d) Mensuração do grau de alavancagem operacional, com base no valor do custo fixo total e da margem de contribuição total.

e) Cálculo do ponto de equilíbrio e acompanhamento da margem de segurança operacional com que a empresa vem operando ou pretende operar.

f) Gerenciamento dos custos com eficiência e eficácia, a partir do conhecimento do seu comportamento.

g) Identificação, utilização e compreensão dos métodos de custeio.

\subsection{Estrutura de custos e despesas}

Conforme Porter (1989, p. 57), o enfoque no custo é uma das estratégias genéricas possível para as empresas e, por outro lado, a gestão de custo pode ser vital para a estratégia de diferenciação, porque um diferenciador deveria analisar seus custos garantir lucratividade. Segundo o autor, o comportamento do custo exerce uma forte influência sobre a estrutura industrial como um todo. É preciso estar atento tanto à estrutura de custos e despesas interna como também à operacionalizada pelos concorrentes.

No entanto, Hesford (1998, p. 25) afirma que “[...] muitos profissionais de inteligência competitiva não sabem nem mesmo a estrutura de custo interna." Conhecer a estrutura de CDT interna é fundamental para avaliar a eficiência das instalações; já a estimação de estrutura de CDT dos concorrentes é importante para monitorar e avaliar a eficiência dos competidores e as suas estratégias competitivas.

Segundo Guerreiro (2011, p. 80), é muito importante conhecer o impacto da estrutura de custos e despesas das empresas no seu desempenho econômico e, segundo o autor, a regra geral é que, quando uma empresa se estrutura fortemente em custos e despesas fixas, ela terá 
maiores lucros quando operar acima do ponto de equilíbrio e terá maiores perdas quando estiver atuando abaixo do ponto de equilíbrio; pelo contrário, uma empresa mais estruturada em termos de custos e despesas variáveis terá menores lucros quando atuar acima do ponto de equilíbrio, porém minimizará o seu risco operacional, porque terá menores perdas quando atuar abaixo do ponto de equilíbrio.

Guerra et al (2007) realizaram uma pesquisa empírica, na qual confirmaram que as empresas com menor proporção de custos variáveis tiveram um maior impacto da variação da receita sobre o lucro; desta forma, o artigo conclui que as organizações devem estar atentas à sua estrutura de custo, pois ela pode influenciar o seu nível de risco operacional.

Existem ações que podem ser implantadas de forma isolada ou combinada como alternativa para melhorar o lucro (GUERREIRO, 2011, p. 75-76), que podem impactar tanto a Margem Operacional (MO) quanto a Rentabilidade Operacional (RO), por exemplo:

- $\quad$ Aumentar a receita total, seja pela quantidade vendida (q), seja pelo preço de venda (p) ou ambos. A variação do preço de venda impacta a margem de contribuição unitária do produto; assim, a redução de $1 \%$ no preço de venda produz um impacto no ponto de equilíbrio que depende do tamanho da margem de contribuição. Quando a margem é pequena, o impacto é relevante. Quando a margem é grande, o impacto é menos relevante.

- Reduzir o custo fixo total. Cada $1 \%$ de aumento no custo fixo proporciona $1 \%$ de aumento no ponto de equilíbrio; desta forma, é preciso vender um volume de $1 \%$ a mais, considerando-se constantes todas as outras variáveis.

- Reduzir o custo variável unitário. A redução do custo variável impacta a margem de contribuição unitária do produto. Assim, a redução no custo variável produz um impacto no ponto de equilíbrio. Quando a margem é grande, o impacto é menos relevante, quando a margem é pequena, o impacto é relevante. 


\subsection{Desempenho econômico}

Porter (1989, p. 95) argumenta que o motivo que leva as empresas a obterem sucesso é a sua estratégia. O autor explica que a definição de sucesso de uma empresa, para ele, está relacionada à obtenção de um desempenho superior ao de seus competidores. Existem diversas maneiras de medir o desempenho de uma organização, entre elas: avaliação financeira (ex.: análise de fluxo de caixa e índices de liquidez), análise da estrutura de capital (ex.: capital próprio ou de terceiros) e desempenho operacional (ex.: técnicas de estatística e de programação linear que poderão calcular o ponto ótimo de produção e consumo de recursos).

Na abordagem da Teoria da Maximização do Valor da Firma, a principal função da organização é aumentar o valor da empresa para os acionistas. Deo (2010a, p. 19) lembra que a responsabilidade sobre essa função cabe aos gestores mais altos da organização e argumenta que a melhor maneira de avaliar o seu desempenho é através do comportamento do preço das ações no mercado; porém, reconhece que esse indicador é impactado por diversas variáveis que estão além do controle dos gestores. Portanto, é preciso estabelecer indicadores de desempenho que reflitam o desempenho dos gestores e da empresa e que sejam incorporados e entendidos pelos membros da organização.

\subsubsection{Desempenho mensurado com base na margem e no retorno operacional}

Deo (2010b, p. 23) argumenta que, apesar das críticas que existem a respeito da avaliação de desempenho baseado em informações contábeis, esses indicadores têm seus benefícios, por serem simples de utilizar e interpretar, e porque são revisados e publicados rotineiramente no processo mensal de fechamento de balanços.

Dos diversos indicadores financeiros comumente utilizados para avaliar desempenho das organizações e dos gestores, coerente com a teoria do crescimento da firma, que prega que as empresas existem para gerar lucros (PENROSE, 2006, p. 68) e também com a teoria da maximização da riqueza do acionista, que prega que o retorno sobre os investimentos dos acionistas devem orientar as decisões dos gestores (JENSEN, 2000, p. 1), decidiu-se utilizar a margem operacional (MO) e o retorno operacional sobre os ativos (RO). O primeiro é obtido na demonstração de resultados do exercício (DRE); já o segundo (RO) utiliza dados da DRE e 
também do balanço patrimonial (BP). As empresas utilizam esses indicadores para estabelecer suas metas tanto no curto quanto no longo prazo (DEO, 2010b, p. 23).

Ross et al (2008, p. 63) afirmam que a margem operacional, retorno sobre os ativos e o retorno sobre o patrimônio líquido são os índices de desempenho mais conhecidos e utilizados de todos os índices financeiros.

\section{a) MARGEM OPERACIONAL}

Penrose (2006, p. 71) designa as firmas como organizações administrativas que têm um conjunto de recursos produtivos, cujo propósito geral é utilizar todos esses recursos para gerar lucros.

A margem operacional é uma medida de desempenho que demonstra o valor trazido para a empresa com base no valor de suas vendas e nos custos e despesas operacionais envolvidos. Pode-se dizer que a lucratividade é determinada quando se compara quantos centavos a empresa lucra por real vendido. Assaf Neto (2008, p. 242) define a MO como: “[...] desempenho da empresa medido em função de valores efetivamente utilizados em suas operações normais.” A MO é, portanto, uma medida de eficiência das empresas que demonstra o valor trazido com base no valor de sua venda e nos recursos envolvidos.

Desse modo, para uma empresa que vende uma unidade de seu produto por \$1 e tem um lucro operacional de \$0,35, diz-se que está trabalhando com uma margem de lucratividade operacional de $35 \%$. Similarmente, se a empresa estiver analisando um cliente que compra $\$ 100.000$ por período e deixa um lucro operacional de $\$ 25.000$, pode-se dizer que está trabalhando, com esse cliente, com uma margem de lucratividade operacional de $25 \%$.

Brealey et al (2003, p. 499) argumentam que a MO é uma medida que elimina o efeito da estrutura de financiamento da empresa, pois a sua fórmula expurga o efeito dos juros pagos ou recebidos. É uma boa medida de desempenho, refletindo tanto os gastos de produção quanto os gastos da estrutura administrativa e comercial. Deste modo, reflete 
os esforços que a empresa realiza, direta ou indiretamente, para que seus produtos sejam produzidos e vendidos no mercado.

Para se calcular a MO é preciso conhecer o lucro operacional (LO), que é o resultado da receita operacional líquida (RL) menos todos os custos e despesas totais (CDT) da empresa objeto de análise, desconsiderando o resultado financeiro (juros pagos ou recebidos). Em seguida divide-se o LO pelo montante da RL.

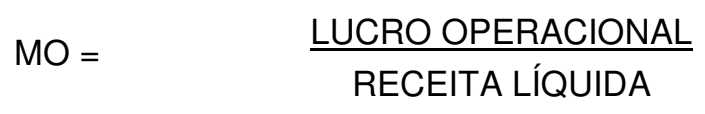

Equação 1 - Margem Operacional

Cabe destacar que a normatização atual sobre demonstração do resultado, emitida pelo Comitê de Pronunciamentos Contábeis (CPC), através do pronunciamento técnico número 26, não contempla o termo Lucro Operacional nas demonstrações financeiras, sendo recomendado o termo Lucro antes do Resultado Financeiro. Na essência, esta tese utilizou essa métrica, porém, com o intuito de analisar as operações, consequentemente, utilizou-se para fins gerenciais a nomenclatura de Lucro Operacional, pois não há restrições para sua utilização no âmbito da Contabilidade Gerencial.

\section{b) RENTABILIDADE OPERACIONAL}

A rentabilidade é uma medida de eficiência que está relacionada com o retorno por unidade monetária investida (ROSS et al, 2008, p. 64). Pode-se dizer que a rentabilidade é determinada quando se compara o montante de centavos ganhos por unidade monetária investida. Desta forma, quando, por exemplo, se analisa o retorno da aplicação em poupança, fala-se de rentabilidade do investimento, ou seja, quanto a poupança gerou de retorno proporcional para o investimento, em certo período, para o investidor.

A rentabilidade pode ser um indicador do desempenho econômico de uma empresa ou unidade de negócio, de um produto, de um cliente, ou qualquer projeto que a empresa possa querer mensurar economicamente e tenha os dados necessários para tal (investimento e resultado). Assim, por exemplo, uma empresa que tiver seus ativos por 
um valor total de $\$ 100.000$ e, em determinando período de tempo, esse investimento gerar um retorno de $\$ 15.000$, significa dizer que, no período analisado, o investimento teve uma rentabilidade de $15 \%$.

Existem duas métricas de rentabilidade amplamente conhecidas no mundo acadêmico e empresarial que devem ser discutidas: taxa de retorno sobre o ativo (TRA) e taxa de retorno sobre o patrimônio líquido (TRPL), sendo, a primeira, uma medida de rentabilidade para a empresa e, a segunda, para os acionistas.

TRA: A taxa de retorno sobre o ativo ou return on assets (ROA) é a medida relacionada à unidade monetária de ativo (ROSS et al, 2008, p. 64). Essa taxa demonstra o retorno do capital investido em ativos da empresa, a rentabilidade que a empresa está obtendo sobre os ativos (ASSAF NETO, 2008, p. 263). Em outras palavras, mede a relação entre o lucro que está sendo gerado pelo total de ativos investidos.

TRPL: A taxa de retorno sobre o patrimônio líquido ou return on equity (ROE) é a medida de eficiência que reflete a rentabilidade do patrimônio dos investidores. Essa taxa demonstra qual é a rentabilidade dos proprietários e quanto a empresa está gerando de lucro para os acionistas. Assim, para se calcular o retorno sobre o patrimônio líquido, é necessário conhecer o valor do lucro líquido da empresa em determinado período e o valor do patrimônio investido pelos acionistas, duas informações que são encontradas nas demonstrações financeiras da organização.

Nesta tese, o objetivo é utilizar apenas a medida de desempenho da empresa (ROA) e não do acionista (ROE), isto porque está se analisando o desempenho da organização e não a eficiência dos investimentos dos acionistas. Assim, para se calcular a taxa de retorno sobre o ativo em determinado período é necessário conhecer o lucro da empresa naquele período e o valor total do ativo envolvido ao longo do período, duas informações que são encontradas nas principais demonstrações contábeis das organizações: balanço patrimonial e demonstração de resultados. Ross et al (2008, p. 64) lembram que tanto o ROA (ou RO, neste trabalho) quanto o ROE são medidas de desempenho ao longo de um período e que "[...] faz certo sentido calculá-los com base nos valores médios de ativo e patrimônio líquido". 
A fórmula da RO consiste da divisão do LO (conforme explicado anteriormente) pelo ativo total da empresa, conforme demonstrado abaixo. Esse cálculo será realizado para cada empresa, ano a ano, com objetivo de se calcular a rentabilidade média no período para as empresas individualmente, bem como a RO média geral das empresas. Para identificar as empresas com desempenho superior e inferior, comparou-se a rentabilidade média individual com a rentabilidade média geral.

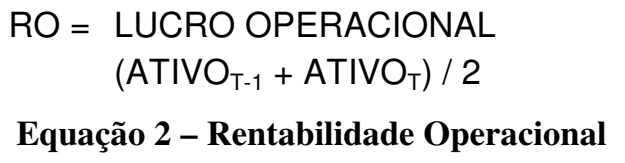

Equação 2 - Rentabilidade Operacional

\subsubsection{Outras métricas utilizadas na prática, mas não nesta tese}

Existem diversas métricas utilizadas para se mensurar desempenho e eficiência de empresas, além das duas já apresentadas. Muitas dessas métricas apresentam variáveis que extrapolam o escopo do campo de decisão dos gestores. Para se manter a coerência entre as teorias que sustentam esta tese e os tipos de métricas utilizadas para mensurar o desempenho das empresas, decidiu-se utilizar apenas a MO e a RO.

A seguir serão apresentadas e discutidas algumas métricas que, apesar de sua grande difusão no campo da avaliação de desempenho, não serão utilizadas nesta tese por apresentarem variáveis que extrapolam as fronteiras das teorias apresentadas.

(a) Valor Econômico Agregado (EVA) ${ }^{4}$

O EVA é o resultado das operações após a remuneração de todas as fontes de financiamento e é uma ferramenta de avaliação de desempenho (BREWER et al, 1999, p. 4). Existem indícios de que esse conceito tenha surgido no início do século XIX a partir dos trabalhos do economista Alfred Marshal; entretanto, o conceito tornou-se mais difundido após a publicação do livro The quest of value (1991), publicado pela consultoria americana Stern Stewart \& Co, que registrou a marca (SHARMA; KUMAR, 2010, p. 203). Lambert e Burduroglu (2000, p. 12) argumentam sobre a importância do

\footnotetext{
${ }^{4}$ Da sigla em inglês Economic Value Added.
} 
EVA como um indicador de desempenho, afirmando que essa medida prioriza a criação de valor e não apenas a preservação.

O grande problema da utilização do EVA para atender ao propósito desta tese está no componente custo do capital, mais especificamente na sua relevância para o cálculo de tal indicador. Para Sharma e Kumar (2010, p. 201), o custo do capital é o aspecto mais importante do EVA. O valor desse componente é geralmente estimado com base nas variáveis de mercado, ou seja, não possui uma influência direta da estrutura de custo e despesas de uma empresa específica. Ross et al (2008, p. 487) recomendam utilizar o modelo CAPM (Capital Assets Pricing Model) para determinar o custo de capital.

Além disso, há outros problemas para estimar o custo de capital em países emergentes. Um dos pressupostos do modelo CAPM é a existência de um mercado maduro, confiável e com baixa volatilidade (ASSAF NETO et al, 2008, p. 74). Adaptar o modelo para estimar o custo de capital de empresas de países emergentes, como o Brasil, requer a utilização de variáveis de países de mercados mais maduros, como o mercado norteamericano, com o acréscimo de um custo prêmio relativo à incerteza do país onde atua, o chamado risco país ou risco soberano. O primeiro a propor tal ajuste foi o professor Aswath Damodaran, da Universidade de New York (DAMODARAN, 1999).

Dessa forma, devido à importância do custo de capital para o cálculo de EVA e da alta subjetividade que geralmente envolve o cálculo dessa variável para empresas brasileiras, decidiu-se não utilizar esse indicador como medida de desempenho para atender aos propósitos desta pesquisa.

(b) Análise por Envoltória de Dados (DEA) ${ }^{5}$

Esse método de análise é uma técnica que utiliza programação linear para avaliar a eficiência relativa de eventos passados resultantes das ações gerenciais (BANKER et al, 1984, p. 1078). Charnes et al (1978, p. 430) explicam que o propósito da técnica é mensurar a eficiência de uma unidade através da máxima proporção de resultados ponderados (output) sobre os recursos ponderados (input).

\footnotetext{
${ }^{5}$ Da sigla em inglês Data Envelopment Analisys.
} 
Os modelos DEA representam um importante indicador de eficiência relativa das unidades avaliadas, podendo também ser considerado um indicador de desempenho de operações. No entanto, para atender aos objetivos propostos nesta tese, sua utilização não é adequada. Existem problemas para utilizar a técnica DEA por conta do tratamento que os modelos dão aos inputs. Embora existam duas variáveis, custo e despesa variável (CDV) e custo e despesa fixa (CDF), tem-se apenas um input (custo e despesa total), e esse input não deve necessariamente ser minimizado. Não é necessariamente no ponto de menor custo e despesa que a empresa teria os maiores retornos, pois não há um tamanho ótimo ou mais lucrativo para as firmas (PENROSE, 2006, p. 40).

Adicionalmente, os modelos da DEA atribuem pesos diferentes às variáveis CDV e CDF de forma matemática e haveria pelo menos duas situações que inviabilizariam os cálculos: (1) poderia haver situação na qual uma das variáveis de input tivesse peso zero, pois é possível nos modelos matemáticos, mas não é viável na realidade dos negócios, pois as empresas não operam com recursos totalmente fixos, nem totalmente variáveis e (2) essa atribuição de peso não estaria levando em consideração a estratégia da empresa, já que a estrutura de custos e despesas de uma organização deve estar alinhada à sua estratégia, além de considerar as características da cadeia de valor (ANDERSON, 2006, p. 2).

Quanto ao tratamento das variáveis de outputs também há um problema quanto à atribuição de pesos através de programação linear, pelos mesmos motivos apresentados sobre os inputs. O objetivo da tese é encontrar a estrutura da composição de custos e despesas que obteve um desempenho econômico superior durante o período estudado, considerando que não há uma hierarquia de importância entre as variáveis de outputs, ou seja, todas as variáveis deveriam ter peso igual a um; dessa forma, deseja-se encontrar uma estrutura de custo na qual todas as variáveis de outputs (MO e RO, no caso) estejam acima da média.

(c) Modelos de previsão de insolvência

Embora o objetivo desta tese seja estimar a composição da estrutura de custos e despesas das empresas que tiveram desempenho econômico acima e abaixo da média 
dos setores pesquisados e, consequentemente, um desempenho superior ou inferior, o modelo aqui proposto não deve ser confundido com instrumentos de previsão de falência de empresas.

Primeiramente, porque ferramentas que visam esse objetivo são apoiadas em modelos preditivos, enquanto que o modelo proposto nesta tese busca entender e interpretar acontecimentos passados, sem o intuito principal de estimar eventos futuros.

Em segundo lugar, os modelos de previsão de insolvência utilizam ferramentas econométricas diferentes das utilizadas nesta tese. Por exemplo, diversos trabalhos que se propõem a prever falência utilizam análise discriminante (BEAVER, 1966; ALTMAN, 1968; KANITZ, 1978; LACHTERMACHER; ESPENCHITTI, 1998) e outros fazem uso de análise de regressão logística (JANOT, 2001; BRITO; ASSAF NETO, 2008).

Também há trabalhos que utilizam outras técnicas; no entanto, os modelos que trabalham com previsão de falência geralmente usam o procedimento de dois grupos emparelhados de empresas, um com empresas classificadas como insolventes, outro com as classificadas como solventes (grupo de controle). Esse emparelhamento tem o objetivo de fazer comparações e previsões de eventos futuros de insolvência, a partir de diversos indicadores (variáveis) analisados nos dois grupos, diferentemente do procedimento que está sendo utilizado nesta pesquisa, o qual não tem um grupo de controle.

Outro ponto importante é que o fenômeno da insolvência, processo que pode levar à falência de empresas, pode ser interpretado de diversas maneiras dependendo da perspectiva do autor. Por exemplo, um dos modelos pioneiros nessa área considera insolvente a empresa que não consiga remunerar seus acionistas conforme a rentabilidade do mercado (ALTMAN, 1968). Outros autores consideram que a empresa torna-se insolvente quando não consegue pagar suas obrigações em dia, aliado ao fato de não possuir ativos suficientes para saldar seus passivos (GITMAN, 1997, p. 757). Essa discussão sobre a natureza do fenômeno da insolvência de empresas não está no escopo desta tese. 
O modelo econométrico utilizado nesta tese é o modelo de regressão múltipla com dados em painel e tem o objetivo de explicar acontecimentos passados relacionados à estrutura de custos e despesas e indicadores do desempenho da empresa; portanto, tratase de um modelo explicativo e não preditivo; daí resulta a principal diferença com modelos de previsão de insolvência.

\subsection{Encerramento do capítulo}

Este capítulo tratou dos principais conceitos que são base para este estudo. Na parte dedicada para estrutura de custos e despesas, utilizou-se dos conceitos de custo e despesa variável $(\mathrm{CDV})$, custo e despesa fixa (CDF) e custo e despesa total (CDT). Dentre as métricas de desempenho econômico optou-se pela utilização da margem operacional (MO) e rentabilidade operacional (RO).

O próximo capítulo explica com detalhes o procedimento metodológico adotado nesta tese para se estimar a estrutura de custo e despesa de um grupo de empresas de dois setores distintos - Têxtil e Siderurgia/Metalurgia - e como foi feita a relação dessa estrutura de custos e despesas com as métricas de desempenho econômico. 
Metodologia é uma sequência de procedimentos estabelecidos para o método científico, bem como consiste em delimitar um problema, realizar observações e interpretá-las com base nas relações encontradas, fundamentando-se em teorias existentes (RICHARDSON, 1999, p. 22). Este capítulo descreve a trajetória metodológica, o caminho percorrido por esta pesquisa para atingir seu objetivo.

Demonstra-se como o fenômeno focalizado na realidade pode ser estudado de forma científica, empregando métodos que correspondam às perspectivas teóricas adotadas, ao mesmo tempo adequados à abordagem do fenômeno a ser investigado. A seguir, é explicado todo o caminho que determinou a escolha da base de dados, das variáveis, a seleção da amostra e o tratamento quantitativo e qualitativo dos dados coletados.

A pesquisa usa uma abordagem teórico-empírica. Segundo Martins e Theóphilo (2009, p. 39), no empirismo, "[...] a ciência é vista como uma descrição dos fatos baseados em observações e experimentos que permitem estabelecer induções.” Os autores destacam ainda algumas contribuições da abordagem empírica, quais sejam:

Defende as ciências sociais de uma especulação desenfreada.

$>$ Contribui para a elaboração de técnicas de coleta de dados submetendo os fenômenos sociais à mensuração (ainda que se pondere sobre a dificuldade de medir qualidade).

$>$ Permite aplicação de vários tipos de métodos e técnicas.

$>$ Desperta a preocupação com a acumulação de dados.

\subsection{Levantamento bibliográfico}

O dia 07 de outubro de 2009 foi a data que formalizou o início desta pesquisa sobre a relação entre a estrutura de custos e despesas e o desempenho das organizações. As dúvidas referentes ao assunto iniciaram-se com base em questionamentos levantados pelo orientador durante as primeiras aulas ministradas em cursos de pós-graduação, por volta do ano de 2006. 
A primeira busca foi para localizar rastros de pesquisas semelhantes. Foram analisados os principais sites de busca de periódicos com palavras-chave que pudessem se relacionar com a dúvida levantada, como, por exemplo: estrutura de custos (cost structure), custos fixos e custos variáveis (fixed and variable costs), entre outros.

O acesso foi às bases de dados do Proquest, Coordenação de Aperfeiçoamento de Pessoal de Nível Superior (Capes), Revista de Administração, Revista Contabilidade e Finanças, entre outras, todas disponíveis na Biblioteca da FEA. No Proquest, em "pesquisa básica" e selecionada a opção "apenas documentos com texto completo", foram disponibilizados diversos documentos, evidenciando que a estratégia de busca precisaria de um maior detalhamento. No campo "pesquisa avançada" foram solicitadas expressões em conjunto (“AND"), como “cost structure" e "cost estimation". Essa estratégia resultou em 26 documentos, demonstrando sucesso no refinamento da busca.

Foi realizada uma leitura dos resumos e das introduções de todos os documentos selecionados para identificar quais trabalhos tinham relação com o objeto de pesquisa desta tese. Alguns artigos foram eliminados por não tratarem do tema de interesse de pesquisa, por serem de autores anônimos ou por não terem validade científica (fonte duvidosa).

Além dessa pesquisa, alguns artigos foram obtidos com base no direcionamento do orientador, com a experiência adquirida pelo pesquisador e, também, na bibliografia dos artigos lidos. Com base na leitura dos artigos, raciocínio lógico e debates acadêmicos, foram delineados: o problema de pesquisa, as justificativas que alicerçam este trabalho e todo o referencial teórico.

\subsection{Amostra de empresas}

A pesquisa se preocupou com a seleção da amostra, de forma não probabilística. Inicialmente, foram extraídas, do software da Economática, informações contábeis de todas as empresas listadas na BMFBovespa que se encontravam ativas em fevereiro de 2011, resultando em um total de 701 registros. No entanto, muitas empresas estavam com informações duplicadas, devido os registros trazerem classe de ativos "ON" (ação ordinária) e "PN" (ação preferencial); assim, foram excluídas todas as classes de ativos diferentes de "ON", pois todas 
as empresas que estão na bolsa de valores tem que ter, pelo menos, ações "ON". O resultado foi que, nessa etapa, foram excluídos 314 registros, resultando em 387 empresas.

O próximo passo de organização do banco de dados foi a verificação de quais empresas não continham informações completas para o horizonte de cinco anos. O resultado é que, nessa etapa, foram eliminadas 148 empresas que estavam nessa situação de falta de informação durante um ou mais períodos, resultando em uma amostra de 239 empresas.

$\mathrm{Na}$ quinta etapa de tratamento dos dados da amostra verificou-se a quantidade de empresas em cada setor, conforme o quadro a seguir:

Quadro 1 - Distribuição de empresas por setor segundo a E
\begin{tabular}{|l|c|}
\hline \multicolumn{1}{|c|}{ SETOR } & TOTAL \\
\hline Energia Elétrica & 32 \\
\hline Têxtil & 25 \\
\hline Siderurgia e Metalurgia & 22 \\
\hline Veículos e peças & 17 \\
\hline Construção & 14 \\
\hline Alimentos e Bebidas & 13 \\
\hline Comércio & 13 \\
\hline Química & 11 \\
\hline Telecomunicações & 11 \\
\hline Transporte e Serviço & 10 \\
\hline Papel e Celulose & 6 \\
\hline Eletroeletrônicos & 5 \\
\hline Máquinas Industriais & 4 \\
\hline Minerais não Metálicos & 4 \\
\hline Petróleo e Gás & 4 \\
\hline Agro e Pesca & 2 \\
\hline Mineração & 2 \\
\hline Software e Dados & 2 \\
\hline Outros & 42 \\
\hline TOTAL & $\mathbf{2 3 9}$ \\
\hline
\end{tabular}

Os setores com maior número de empresas classificadas são "outros" e "energia elétrica" com 42 e 32 empresas respectivamente. No entanto, ambos foram descartados por motivo de heterogeneidade. No caso do primeiro, a heterogeneidade é mais óbvia, pois existem diversos tipos de empresas envolvidas.

O setor de energia elétrica foi utilizado como teste para a etapa de qualificação desta tese e, por decisão dos integrantes da banca, não se utilizou esse setor para a pesquisa final, por 
haver algumas dificuldades que não permitiam que fosse aprofundada a pesquisa, como, por exemplo: heterogeneidade de segmentos em diversas empresas classificadas nesse setor, regras contábeis próprias, estrutura de custo bem diversificada entre as atividades de geração, transmissão, distribuição e comercialização, já que as empresas não separam as informações por esses macroprocessos. Além disso, a regulamentação do setor de energia elétrica passou por mudanças recentes que poderiam influenciar na análise.

Feitas essas exclusões, o setor que apresentou o maior número de empresas foi o setor Têxtil (25 empresas). Para se ter uma comparabilidade entre setores, decidiu-se selecionar também o próximo setor com maior número de empresas: Siderurgia/Metalurgia (22 empresas).

Definidos os setores, foi realizada ainda uma análise para verificar a existência de outliers que poderiam distorcer a análise. O critério para identificar a existência de outliers foi o montante do ativo imobilizado e o da receita líquida, e o método utilizado foi o boxplot.

- $\quad$ No setor Têxtil foram encontrados quatro outliers.

- $\quad$ No setor de Siderurgia/Metalurgia foram identificados cinco outliers.

Os outliers de cada setor foram excluídos; então, a quantidade de empresas estudadas nos setores Têxtil e Siderurgia/Metalurgia passou a ser de 21 e 17, respectivamente. A análise de outliers dos dois setores encontra-se no Apêndice 1.

Verificou-se também, com base nas demonstrações financeiras enviadas a BMFBovespa, a atividade principal de cada uma das empresas selecionadas e constatou-se que existiam duas Holdings no grupo de empresas do setor Têxtil e uma no setor Siderurgia/Metalurgia. Além disso, duas empresas classificadas como Siderurgia/Metalurgia pela Economática foram eliminadas também, pois suas atividades principais nada tinham a ver com as atividades comuns desse setor.

Após todas as eliminações e aglomerações, a amostra final por setor ficou com 19 empresas no setor Têxtil e 14 no setor Siderurgia/Metalurgia, conforme Quadro 2. 
Quadro 2 - Relação das empresas analisadas em cada setor

\begin{tabular}{|c|c|c|c|c|c|}
\hline \multicolumn{3}{|c|}{ TÊXTIL } & \multicolumn{3}{|c|}{ SIDERURGIA/METALURGIA } \\
\hline$\#$ & Nome & Atividade Principal & $\#$ & Nome & Atividade Principal \\
\hline 1 & Alpargatas & $\begin{array}{l}\text { indústria e comércio de } \\
\text { calçados e artigos } \\
\text { esportivos }\end{array}$ & 1 & Aco Altona & fundição de ferro e aço \\
\hline 2 & $\begin{array}{l}\text { Botucatu } \\
\text { Tex }\end{array}$ & indústria de roupas & 2 & Aliperti & $\begin{array}{c}\text { fabricação de peças e acessórios para o } \\
\text { sistema de direção e suspensão de } \\
\text { veículos automotores }\end{array}$ \\
\hline 3 & Buettner & banho e cama & 3 & Confab & $\begin{array}{l}\text { produção de bens de capital por } \\
\text { encomenda } \\
\end{array}$ \\
\hline 4 & Cambuci & artigos esportivos (penalty) & 4 & Ferbasa & fabricação de ferro ligas \\
\hline 5 & Cedro & indústria têxtil & 5 & Fibam & $\begin{array}{c}\text { fabricação de peças e acessórios para } \\
\text { veículos automotores, tais como } \\
\text { parafusos, porcas, arruelas, roscas e } \\
\text { similares. }\end{array}$ \\
\hline 6 & Cia Hering & $\begin{array}{l}\text { confecção de artigos do } \\
\text { vestuário e acessórios }\end{array}$ & 6 & $\begin{array}{l}\text { Forjas } \\
\text { Taurus }\end{array}$ & indústria e comércio de armas \\
\hline 7 & Cremer & $\begin{array}{c}\text { indústria e comércio de } \\
\text { produtos têxteis (tecidos e } \\
\text { não tecidos) }\end{array}$ & 7 & Haga S/A & $\begin{array}{l}\text { indústria metalúrgica - fab. de } \\
\text { fechaduras p/construção civil }\end{array}$ \\
\hline 8 & Dohler & $\begin{array}{c}\text { fabricação de artefatos } \\
\text { têxteis para uso doméstico }\end{array}$ & 8 & $\begin{array}{l}\text { Kepler } \\
\text { Weber }\end{array}$ & $\begin{array}{l}\text { relacionadas a metalurgia, importação e } \\
\text { exportação. }\end{array}$ \\
\hline 9 & $\begin{array}{l}\text { Fab C } \\
\text { Renaux }\end{array}$ & $\begin{array}{l}\text { produçãa de tecidos de } \\
\text { algodão }\end{array}$ & 9 & Met Duque & $\begin{array}{l}\text { fabricação de peças p/ bicicletas, peças } \\
\text { p/eletrodomésticos e linha automotiva }\end{array}$ \\
\hline 10 & Grendene & $\begin{array}{c}\text { fabricação de calçados em } \\
\text { geral }\end{array}$ & 10 & $\begin{array}{l}\text { Metal } \\
\text { Iguacu }\end{array}$ & $\begin{array}{l}\text { fábrica de embalagens metálicas para } \\
\text { alimentos }\end{array}$ \\
\hline 11 & $\begin{array}{c}\text { Ind } \\
\text { Cataguas }\end{array}$ & $\begin{array}{l}\text { fabricação, comércio, } \\
\text { importação e exportação } \\
\text { de fios e tecidos. }\end{array}$ & 11 & Metisa & $\begin{array}{l}\text { fabricação de máquinas e equipamentos } \\
\text { para a agricultura e pecuária. peças e } \\
\text { acessórios. exceto para irrigação }\end{array}$ \\
\hline 12 & Karsten & $\begin{array}{l}\text { fabricação e comércio de } \\
\text { fios, tecidos e produtos } \\
\text { têxteis em geral. } \\
\end{array}$ & 12 & Panatlantica & $\begin{array}{l}\text { industrialização e comercialização de } \\
\text { aços planos }\end{array}$ \\
\hline 13 & Pettenati & $\begin{array}{l}\text { fabricação de tecidos } \\
\text { acabados em malha } \\
\text { circular }\end{array}$ & 13 & Rimet & $\begin{array}{l}\text { fabricação de embalagens metálicas para } \\
\text { acondicionamento de alimentos. } \\
\text { produtos químicos. entre outros }\end{array}$ \\
\hline 14 & Santanense & indústria têxtil & 14 & Tekno & pintura de bobinas e chapas metálicas \\
\hline 15 & Schlosser & tecidos para vestuário & & & \\
\hline 16 & Tecel S Jose & $\begin{array}{l}\text { fabricação, comércio e } \\
\text { exportação de produtos } \\
\text { têxteis. }\end{array}$ & & & \\
\hline 17 & Teka & $\begin{array}{l}\text { fabricação de artigos de } \\
\text { cama, mesa e banho }\end{array}$ & & & \\
\hline 18 & Tex Renaux & $\begin{array}{l}\text { fiação e tecelagem de } \\
\text { algodão }\end{array}$ & & & \\
\hline 19 & Vulcabras & $\begin{array}{c}\text { com. impor. em geral } \\
\text { notadamente de calçados e } \\
\text { roupas }\end{array}$ & & & \\
\hline
\end{tabular}




\subsection{Variáveis do modelo}

Para atender ao primeiro objetivo deste estudo - "estimar a composição da estrutura de custos e despesas média dos setores selecionados, em termos de fixos e variáveis" - o modelo foi construído a partir de três variáveis:
a) Custos e despesas totais (CDT);
b) Receita líquida (REC);
c) Ativo imobilizado (IMOB).

Custos e despesas totais (CDT) representam a variável dependente no modelo, enquanto que as outras duas (REC e IMOB) representam as variáveis explicativas, por meio das quais se pretende estimar o percentual de participação entre custos e despesas fixas (CDF) e custos e despesas variáveis (CDV) contidos nos CDT.

\subsubsection{Custos e despesas totais (CDT)}

Como medida representativa de CDT, o modelo considera os seguintes elementos da demonstração de resultados de exercício (DRE) das empresas pesquisadas, com base na nomenclatura utilizada pela Economática: custo de produtos vendidos (CPV); despesas de vendas (DV); despesas de administração (DA); e outras receitas e despesas operacionais (ORDOP). Esta medida capta todos os custos e despesas operacionais registrados nas DREs das empresas.

Quadro 3 - Composição dos custos e despesas totais (CDT)

\begin{tabular}{|l|c|}
\hline CUSTO DOS PRODUTOS VENDIDOS & CPV \\
\hline DESPESAS DE VENDAS & DV \\
\hline DESPESAS DE ADMINISTRAÇÃO & DA \\
\hline OUTRAS RECEITAS E DESPESAS OPERACIONAIS & ORDOP \\
\hline CUSTOS E DESPESAS TOTAIS & CDT \\
\hline
\end{tabular}




\subsubsection{Receita líquida (REC)}

Conforme definido no capítulo anterior, os CDV são afetados diretamente pelo volume de produção. Contudo, muitas vezes, a informação direta sobre o volume de produção das empresas não está disponível publicamente e, também, não é auditada. Por esse motivo, é comum encontrar-se publicações acadêmicas que utilizam proxies para representar essa variável.

A proxy, segundo Wooldridge (2006, p. 278), é uma variável que está relacionada com a variável não observada que deve ser controlada na análise. Contudo, o autor adverte que uma proxy pode gerar viés na estimação da variável dependente se ela não estiver relacionada com a variável não observada.

Verifica-se a utilização de receita como proxy de volume de produção em algumas pesquisas acadêmicas. Casella (2008) busca estimar a estrutura de custos de quatro empresas do setor de celulose e papel, onde a receita de vendas é utilizada como proxy do volume de produção. Anthony e Govindarajan (2008, p. 432) utilizam a variação da receita como proxy representativa da variação do volume de produção para explicar o comportamento dos custos variáveis.

Maher (2001, p. 453) argumenta que "[...] receitas alteram-se proporcionalmente ao volume", porém o autor também adverte que essa pressuposição de linearidade só é válida em determinado intervalo de atividade "[...] e que aproxima-se da realidade o suficiente para não distorcer grandemente os resultados da análise."

Nesta tese, a receita líquida (REC) é utilizada como proxy do volume de produção das empresas, portanto, é a variável que representa os custos e despesas variáveis. Cabe ressaltar, todavia, que existem situações em que há aumento das receitas sem que isso tenha sido provocado pelo aumento do volume de produção, por exemplo, variações nos preços dos produtos, taxa de câmbio etc. Esta será uma limitação do modelo, uma vez que a informação de volume não pode ser obtida publicamente. 


\subsubsection{Ativo imobilizado (IMOB)}

A variável ativo imobilizado (IMOB) é utilizada no modelo econométrico para representar a participação dos custos e despesas fixas no custo e despesa total. Essa é uma proxy utilizada para representar algo que está relacionado com a variável não observada que deve ser controlada na análise (custos e despesas fixas).

Alguns autores (MARTINS; ROCHA, 2010; MARTINS, 2010, BLOCHER et al, 2010) citam como possíveis exemplos de custos e despesas fixas: imposto predial e territorial urbano (IPTU), manutenção predial, seguros e gastos com vigilância, limpeza, aluguel, depreciação etc. Esses custos e despesas costumam estar relacionados ao valor dos ativos imobilizados.

A inclusão dessa variável no modelo deu-se pelo fato de ela representar uma proxy de custos e despesas fixas, pois está relacionada com a estrutura da empresa e não varia em função do volume, dentro de determinado intervalo. VanDerbeck e Nagy (2003, p. 444) argumentam que estes custos e despesas fixas "[...] tendem a permanecer os mesmos sobre certa amplitude de atividade, mas que aumentam quando a produção excede certos limites."

Conforme visto no referencial teórico, o ativo imobilizado pode representar a dimensão da estrutura física produtiva da organização; portanto esses recursos fixos geram gastos e variam de uma empresa para outra ou mesmo dentro da própria empresa no horizonte de tempo analisado. Nesta tese, considera-se que o crescimento do IMOB contribui para a variação da participação dos custos e despesas fixas nos CDT e é representado no modelo por um coeficiente beta $(\beta)$. Espera-se que esse coeficiente seja positivo em relação aos CDT, ou seja, quando os CDF aumentam, os CDT também aumentam. No entanto, é esperado também que ele apresente um valor menor do que o coeficiente $(\beta)$ das REC, uma vez que, geralmente, as receitas líquidas são mais fortemente correlacionadas aos CDT.

\subsubsection{Transformação das variáveis}

Shank e Govindarajan (1993, p. 194-195) sugerem a utilização da escala log-log em modelos de estimação de custo e comentam que essa “[...] é uma artimanha matemática bem conhecida, que converte relações curvilíneas em linha reta." Com o objetivo de linearizar e homogeneizar as variáveis, conforme sugerido pelos autores, foram utilizados os valores do logaritmo 
neperiano das seguintes variáveis: ln dos custos e despesas totais (LNCDT), ln da receita líquida (LNREC) e ln do ativo imobilizado (LNIMOB).

Além do benefício de linearização, a transformação em escala log-log impõe menos restrições à função custos associada à função de produção de Cobb-Douglas ${ }^{6}$ (BURDISSO, 1997, p. 9). Um aspecto atraente do modelo log-log, que o tornou muito difundido nos trabalhos aplicados, é que o coeficiente angular mede a elasticidade da variável explicativa em relação à variável dependente (GUJARATI, 2006, p. 142). Por exemplo, é possível estimar a elasticidade das REC em relação aos CDT, ou seja, dado um aumento de REC estima-se em quanto os CDT serão acrescidos. Esta análise também é interessante para comparação dos setores.

\subsection{Modelos de regressão com dados em painel}

O modelo de regressão múltipla é uma ferramenta estatística para estimar efeitos sobre uma variável dependente por meio da utilização de variáveis que possam explicar o seu comportamento (variáveis explicativas). Segundo Wooldridge (2006, p. 64), o modelo de regressão múltipla ainda é o veículo mais usado da análise empírica em economia e em outras ciências sociais.

No entanto, é importante destacar que um modelo estatístico é apenas uma aproximação da realidade e, portanto, incapaz de captar todas as forças que estão agindo sobre a variável que se pretende estimar. Essas forças omissas são as variáveis não observadas.

Contudo, existe uma técnica de Econometria para controlar essas variáveis não observadas, que é a regressão com dados em painel (STOCK; WATSON, 2004). O método de dados em painel trabalha com duas dimensões, uma espacial (cross-sections) e outra temporal (GUJARATI, 2006); com isso, o modelo consegue anular o efeito das variáveis não observadas que variam entre as entidades, mas que são constantes ao longo do tempo, reduzindo, assim, o viés da variável omitida (STOCK; WATSON, 2004, p. 188). Por exemplo, pode-se citar o efeito da estratégia de cada uma das empresas, que, provavelmente, é diferente

\footnotetext{
${ }^{6}$ As propriedades da função Cobb-Douglas são: (1) os coeficientes angulares medem as elasticidades das variáveis explicativas; e (2) O somatório dos coeficientes angulares informa sobre os retornos de escala. Quando a soma dos coeficientes é igual a um, há retorno constante de escala; quando o somatório é maior do que um há retorno crescente de escala; e quando a soma é menor do que um, há retorno decrescente de escala.
} 
em cada entidade, mas, ao longo do tempo, é constante na mesma entidade, ou se altera com base mais longa de tempo.

Gujarati (2006, p. 514) lista as principais vantagens de utilização de dados em painel. Segundo o autor, os benefícios da utilização dessa técnica são: lida melhor com a maior heterogeneidade da amostra; reduz a colinearidade entre as variáveis e aumenta o número de graus de liberdade; verifica melhor a dinâmica da mudança no período estudado; verifica o efeito/repercussão de um evento ao longo do tempo; é adequado também para analisar eventos comportamentais, como economia de escala e mudança tecnológica; e reduz o viés da amostra pela possibilidade de agregação de milhares de dados.

Existem três tipos de modelos de regressão com dados em painel: o modelo pooling, efeitos aleatórios e o modelo de regressão com efeitos fixos. Este último, de acordo com Stock e Watson (2004, p. 190), é um método para controlar variáveis omitidas em dados em painel quando elas variam entre entidades, mas não ao longo do tempo. A regressão possui " $n$ " interceptos, um para cada entidade. Essa técnica capta no próprio intercepto o efeito da variável não observada (STOCK; WATSON, 2004, p. 190); assim, o modelo de regressão com dados em painel com efeito fixo se torna:

$$
Y i t=\beta_{1} X_{i t}+\beta_{2} X_{i t}+\alpha_{i}+\mu_{i t}
$$

\section{Equação 3 - Função modelo da regressão}

onde $\alpha_{i}=\beta_{0}+\beta_{3} Z_{i}$, em que $\alpha_{i}, \ldots \alpha_{n}$ são tratados como interceptos desconhecidos a serem estimados, um para cada entidade, formados a partir do intercepto geral mais o intercepto específico das entidades.

Dados em painel, portanto, consistem em observações das mesmas $n$ entidades para dois ou mais períodos de tempo $t$. Se a base de dados contém observações sobre variáveis $\mathrm{X}$ e Y, os dados são representados como: (Xit, Yit), $i=1, \ldots, n$ e $t=1, \ldots, T$, onde o primeiro subscrito, $i$, refere-se à entidade em observação e o segundo subscrito, $t$, refere-se à data em que ela foi observada. 


\subsection{Estimando os modelos de regressão com dados em painel}

Para desenvolver os modelos de regressão com dados em painel foi utilizado o software estatístico Eviews. Existem três modelos para gerar regressão com dados em painel: (1) pooling, (2) efeitos fixos (EF), e (3) efeitos aleatórios (EA).

O primeiro modelo - pooling - é o mais simples e não considera as duas dimensões do painel; considera cada observação como uma entidade independente e parte da premissa de que todos os coeficientes são constantes ao longo do tempo e entre os indivíduos (GUJARATI, 2006, p. 517).

O modelo de efeitos fixos (EF) considera o efeito de variação entre entidades e do tempo; pode ser estimado de quatro maneiras: (a) com coeficiente angular constante e intercepto variando entre entidades; (b) com coeficiente angular constante e intercepto variando com o tempo; (c) com coeficiente angular constante e intercepto variando entre entidades e com o tempo; e (d) com todos os coeficientes variando entre as entidades ao longo do tempo.

Já o modelo de efeitos aleatórios (EA) também considera o efeito de variação entre entidades e do tempo, e é constituído sob a premissa de que o intercepto é uma extração aleatória de uma população muito maior e que os erros gerados não são correlacionados com os parâmetros utilizados no modelo (GUJARATI, 2006).

Para determinar qual seria o modelo mais adequado para este estudo, realizou-se um exercício em que foram geradas regressões em cada um dos três modelos, que será explicado a seguir.

\subsubsection{O Modelo Pooling}

Inicialmente, para gerar os modelos de regressão no Eviews, os dados financeiros de todas as entidades devem ser organizados de forma que o software possa interpretá-los como dados em painel. Como foi dito, o primeiro modelo a ser testado foi o pooling, que tem a seguinte notação: 


$$
Y_{i t}=\beta_{1}+\beta_{2} X_{2 i t}+\beta_{3} X_{3 i t}+\mu_{i t}
$$

Equação 4 - Função modelo pooling

no qual os parâmetros a serem estimados $\beta_{2} X_{2 i t}$ e $\beta_{3} X_{3 i t}$ representam a receita líquida (REC) e o ativo imobilizado (IMOB) respectivamente; o parâmetro $\beta_{1}$ é o intercepto comum a todas as entidades ao longo do tempo e $\mu_{i t}$ representa o termo de erro. Esse modelo opera como se todas as variáveis fossem empilhadas e estimassem uma regressão comum, desconsiderando os efeitos de tempo e espaço. Gujarati (2006, p. 517) define esse modelo como a "maneira mais simples e possivelmente ingênua" de trabalhar com dados em painel. O Apêndice 2 mostra os resultados gerados para o modelo pooling.

\subsubsection{O Modelo de Efeitos Fixos}

Conforme destacado, existem quatro maneiras de se estimar o modelo de regressão com dados em painel com efeitos fixos.

a) Coeficiente angular constante e intercepto variando entre as entidades:

Segundo Gujarati (2006, p. 517), esse modelo "[...] leva em conta a individualidade de cada unidade do corte transversal." Nesse modelo considera-se que a inclinação da reta de REC e IMOB (coeficientes angulares) é comum entre as entidades, porém cada organização apresenta um intercepto (custos e despesas fixas) diferenciado. Essa diferença no intercepto representa a influência das variáveis omitidas ou não observáveis, mas que impactam os CDF.

b) Coeficiente angular constante e intercepto variando com o tempo:

Esse modelo consiste em criar uma variável dummy aditiva - impactando o intercepto para cada ano, para verificar se há um impacto significativo do efeito tempo sobre o nível de custo e despesa, mantendo fixa a inclinação da reta de REC e IMOB. 
c) Coeficiente angular constante, intercepto variando entre entidades e com o tempo:

Esse modelo consiste em se criar variáveis dummies aditivas tanto para os indivíduos quanto para os períodos de tempo. O objetivo agora é verificar se, quando as dummies de entidade são combinadas com as de tempo, elas tornam-se significativas e explicam melhor a variação dos custos e despesas totais. Espera-se nesse modelo uma elevação do $\mathrm{R}^{2}$, em razão da inclusão de mais variáveis, mas, por outro lado, haverá uma redução do grau de liberdade pelo mesmo motivo.

d) Todos os coeficientes variando entre as entidades:

O quarto modelo de regressão com efeito fixo consiste em criar variáveis dummies tanto aditivas, para os interceptos individuais, quanto multiplicativas, para os coeficientes angulares (CA) individuais de REC e IMOB de cada entidade. Da mesma maneira que o modelo anterior, espera-se uma elevação no $\mathrm{R}^{2}$ por conta da inclusão de tantas variáveis no modelo.

Todos os quatro modelos de efeitos fixos foram testados e aquele que apresentou resultado mais adequado foi o primeiro modelo, com coeficiente angular constante e intercepto variando entre os indivíduos, visto que nos outros modelos, quando incluídas variáveis dummies, não foram estatisticamente significativas. No Apêndice 3 encontram-se os resultados da regressão com efeito fixo.

\subsubsection{O Modelo de Efeitos Aleatórios}

No modelo de EA, o intercepto varia entre entidades, mas não ao longo do tempo, e os coeficientes angulares (CA) são constantes para todos os indivíduos e em todos os períodos de tempo. A diferença entre os modelos de EF e EA está no tratamento do intercepto. No modelo de EA, o intercepto é composto pelo intercepto do modelo de EF, que capta as diferenças específicas das entidades, e por um intercepto populacional (DUARTE et al, 2007). Partindo do modelo de EF visto anteriormente, tem-se: 


$$
Y_{i t}=\beta_{1 i}+\beta_{2} X_{2 i t}+\beta_{3} X_{3 i t}+\mu_{i t}
$$

Equação 5 - Função modelo efeitos aleatórios

A principal diferença para o modelo de EA está no intercepto, que deve ser interpretado como $\beta_{1 i}=\beta_{1}+\varepsilon_{i}$, onde $\varepsilon i$ é o erro aleatório devido ao intercepto ser uma extração aleatória de uma população muito maior com média constante (GUJARATI, 2006). Assim, o modelo de EA pode ser expresso da seguinte forma:

$$
Y_{i t}=\beta_{1}+\beta_{2} X_{2 i t}+\beta_{3} X_{3 i t}+\varepsilon_{i}+\mu_{i t}
$$

\section{Equação 6 - Função modelo efeitos aleatórios adaptado}

Também foi gerado modelo de regressão com efeito aleatório para os dois setores pesquisados e os resultados são demonstrados no Apêndice 4.

\subsection{Selecionando o modelo adequado}

Para selecionar o modelo a ser utilizado é preciso realizar testes estatísticos que irão mostrar qual é o modelo adequado para os dados que serão utilizados. Primeiramente é preciso realizar o teste para decidir entre o modelo pooling e o modelo de efeitos fixos; essa decisão é tomada a partir do resultado do teste de redundância de efeitos fixos no Eviews.

Nesse teste a hipótese nula é de que há redundância em se utilizar o modelo de efeitos fixos. Como $\mathrm{H}_{0}$ foi rejeitada ao nível de significância de 5\%, para os dois setores foi confirmado que o modelo de efeitos fixos é preferível ao modelo pooling. Os resultados dos testes para os dois setores encontram-se nas Tabelas 1 e 2.

Tabela 1 - Teste de redundância de efeitos fixos para o setor Têxtil

\begin{tabular}{|c|c|c|c|}
\hline Effects Test & Statistic & d.f. & Prob. \\
\hline Cross-section F & 3.172 .693 & $-20,83$ & 0.0001 \\
\hline Cross-section Chi-square & 59.626 .337 & 20 & 0.0000 \\
\hline
\end{tabular}


Tabela 2 - Teste de redundância de efeitos fixos para o setor de Siderurgia/Metalurgia

\begin{tabular}{|l|c|c|c|c|}
\hline Effects Test & & Statistic & d.f. & Prob. \\
\hline Cross-section F & & 8,702516 & $-16,66$ & 0.0000 \\
\hline Cross-section Chi-square & & 96,434758 & 16 & 0.0000 \\
\hline
\end{tabular}

Depois do teste de redundância, é preciso verificar qual é a abordagem de painel mais adequada (de efeitos fixos ou aleatórios). Para isso foi realizado o teste de Hausman. Nesse teste a hipótese nula é de que os resíduos gerados pelo modelo não são correlacionados com as variáveis explicativas, ou seja, se a hipótese nula for aceita, o modelo de efeitos aleatórios é o mais adequado.

O resultado do teste de Hausman para os setores Têxtil e Siderurgia/Metalurgia mostram que não há evidências para aceitar $\mathrm{H}_{0}$ ao nível de significância de $5 \%$, portanto para ambos os setores o modelo de efeitos fixos é o mais adequado. Os resultados são evidenciados nas Tabelas 3 e 4 .

Tabela 3 - Teste de Hausman para o setor Têxtil

\begin{tabular}{|l|c|c|c|}
\hline \multicolumn{3}{|c|}{ Correlated Random Effects - Hausman Test } \\
\hline Test cross-section random effects & & & \\
\hline Test Summary & Chi-Sq. Statistic & Chi-Sq. d.f. & Prob. \\
\hline Cross-section random & 5,840201 & 1 & 0.0157 \\
\hline
\end{tabular}

Tabela 4 - Teste de Hausman para o setor de Siderurgia/Metalurgia

\begin{tabular}{|l|c|c|l|}
\hline \multicolumn{3}{|c|}{ Correlated Random Effects - Hausman Test } \\
\hline Test cross-section random effects & & & \\
\hline Test Summary & Chi-Sq. Statistic & Chi-Sq. d.f. & Prob. \\
\hline Cross-section random & 11,069209 & & 0.0039 \\
\hline
\end{tabular}

\subsection{Estimando a estrutura de custos e despesas das amostras}

Depois de comprovado qual tipo de regressão era o mais adequado (efeitos fixos), foram gerados os modelos para os dois setores, em que a variável dependente a ser estimada foi o CDT, e a etapa seguinte consistiu em calcular a participação dos CDF e CDV contida nesse valor estimado. Com esse procedimento calculou-se a estrutura de custos e despesas de cada empresa, ano a ano. 
Com base nos valores reais observados no período para cada empresa, no intercepto individual e nos coeficientes angulares gerados pelo modelo estatístico, estima-se a participação dos CDF e CDV. Segue, como exemplo, o procedimento adotado para a empresa 1, do setor Têxtil.

Tabela 5 - Exemplo de cálculo da estrutura de custo e despesa da empresa 1 do setor Têxtil

\begin{tabular}{|c|c|c|c|c|c|c|c|c|c|}
\hline Ano & LNCDT & LNREC & Inter. Indiv. & C.A. Receita & $\begin{array}{c}\text { CDT } \\
\text { estimado }\end{array}$ & CDF & CDV & CDF & CDV \\
\hline 2005 & 13,985 & 14,121 & 2,895 & 0,786 & 13,995 & 2,895 & 11,100 & $20,68 \%$ & $79,32 \%$ \\
\hline 2006 & 13,889 & 14,122 & 2,895 & 0,786 & 13,996 & 2,895 & 11,101 & $20,68 \%$ & $79,32 \%$ \\
\hline 2007 & 13,944 & 14,070 & 2,895 & 0,786 & 13,955 & 2,895 & 11,060 & $20,74 \%$ & $79,26 \%$ \\
\hline 2008 & 14,204 & 14,322 & 2,895 & 0,786 & 14,153 & 2,895 & 11,258 & $20,45 \%$ & $79,55 \%$ \\
\hline 2009 & 14,379 & 14,511 & 2,895 & 0,786 & 14,302 & 2,895 & 11,407 & $20,24 \%$ & $79,76 \%$ \\
\hline & & & & & & & Média & $20,56 \%$ & $79,44 \%$ \\
\hline
\end{tabular}

Nesse exemplo, a função custo da empresa 1 do setor Têxtil, no ano de 2005, pode ser escrita da seguinte forma:

$$
L_{N C D T} ; ; 2005=\beta_{1 ; 2005}+\beta_{2 ; 2005} L N R E C+\varepsilon
$$

Equação 7 - Função custo da empresa 1 do setor Têxtil do ano de 2005

Substituindo:

$$
13,995=2,895+(0,786 \times 14,121
$$

Equação 8 - Função custo da empresa 1 do setor Têxtil do ano de 2005 com os números da Tabela 5

Lembrando que o valor do intercepto individual $(\beta 1)$ é composto por um intercepto geral do setor mais um intercepto específico da empresa, sendo constante ao longo do tempo e diferente entre as empresas. Do valor de CDT estimado neste exemplo a proporção de CDF da empresa 1 para o ano 2005 é 20,68\% (2,895/13,995). Este procedimento foi repetido para todas as empresas de cada setor para se estimar a estrutura de custos e despesas média do período de cada empresa, bem como a média de todas as empresas dos setores. As Tabelas 6 e 7 trazem os resumos dos valores estimados de CDF e CDV para cada uma das empresas, nos dois setores. 
Tabela 6 - Estrutura de custo e despesa das empresas do setor Têxtil

\begin{tabular}{|c|c|c|}
\hline EMPRESA & $\begin{array}{c}\text { Média } \\
\text { CDF }\end{array}$ & $\begin{array}{c}\text { Média } \\
\text { CDV }\end{array}$ \\
\hline 1 & $20,56 \%$ & $79,44 \%$ \\
\hline 2 & $24,00 \%$ & $76,00 \%$ \\
\hline 3 & $21,80 \%$ & $78,20 \%$ \\
\hline 4 & $21,31 \%$ & $78,69 \%$ \\
\hline 5 & $21,17 \%$ & $78,83 \%$ \\
\hline 6 & $20,15 \%$ & $79,85 \%$ \\
\hline 7 & $21,01 \%$ & $78,99 \%$ \\
\hline 8 & $21,70 \%$ & $78,30 \%$ \\
\hline 9 & $22,07 \%$ & $77,93 \%$ \\
\hline 10 & $20,54 \%$ & $79,46 \%$ \\
\hline 11 & $20,78 \%$ & $79,22 \%$ \\
\hline 12 & $21,05 \%$ & $78,95 \%$ \\
\hline 13 & $21,02 \%$ & $78,98 \%$ \\
\hline 14 & $20,48 \%$ & $79,52 \%$ \\
\hline 15 & $23,75 \%$ & $76,25 \%$ \\
\hline 16 & $23,19 \%$ & $76,81 \%$ \\
\hline 17 & $22,30 \%$ & $77,70 \%$ \\
\hline 18 & $20,54 \%$ & $79,46 \%$ \\
\hline 19 & $20,76 \%$ & $79,24 \%$ \\
\hline Média Geral & $\mathbf{2 1 , 4 8 \%}$ & $\mathbf{7 8 , 5 2 \%}$ \\
\hline
\end{tabular}

Tabela 7 - Estrutura de custo e despesa das empresas do setor de Siderurgia/Metalurgia

\begin{tabular}{|c|c|c|}
\hline EMPRESA & $\begin{array}{c}\text { Média } \\
\text { CDF }\end{array}$ & $\begin{array}{c}\text { Média } \\
\text { CDV }\end{array}$ \\
\hline 1 & $30,59 \%$ & $69,41 \%$ \\
\hline 2 & $32,16 \%$ & $67,84 \%$ \\
\hline 3 & $30,34 \%$ & $69,66 \%$ \\
\hline 4 & $30,35 \%$ & $69,65 \%$ \\
\hline 5 & $30,78 \%$ & $69,22 \%$ \\
\hline 6 & $30,35 \%$ & $69,65 \%$ \\
\hline 7 & $31,21 \%$ & $68,79 \%$ \\
\hline 8 & $31,79 \%$ & $68,21 \%$ \\
\hline 9 & $31,25 \%$ & $68,75 \%$ \\
\hline 10 & $31,94 \%$ & $68,06 \%$ \\
\hline 11 & $30,56 \%$ & $69,44 \%$ \\
\hline 12 & $31,25 \%$ & $68,75 \%$ \\
\hline 13 & $31,80 \%$ & $68,20 \%$ \\
\hline 14 & $30,60 \%$ & $69,40 \%$ \\
\hline Média Geral & $\mathbf{3 1 , 0 7 \%}$ & $\mathbf{6 8 , 9 3 \%}$ \\
\hline
\end{tabular}

Observa-se que os setores possuem características de estrutura de custo e despesas distintas, enquanto as empresas do setor Têxtil possuem proporção de CDF de 21,48\%, as do setor Siderurgia/Metalurgia possuem proporção de CDF de 31,07\%. 


\subsection{Identificação da relação entre estrutura de custo e despesa}

Uma vez estimada a participação de CDF e CDV para cada uma das entidades nos dois setores estudados, a etapa seguinte foi verificar as medidas de desempenho associadas com cada estrutura de custo e despesa. Para realizar tal mensuração foram utilizadas informações patrimoniais e de resultado dessas empresas que estão disponíveis publicamente. Os cálculos da margem operacional $(\mathrm{MO}=\mathrm{LO} / \mathrm{RL})$ e da rentabilidade operacional $\left(\mathrm{RO}=\mathrm{LO} /\left(\mathrm{A}_{\mathrm{t}-1}+\right.\right.$ $\left.A_{t}\right) / 2$ ) de cada ano para cada empresa foram realizados conforme explicações no item 2.5.1. Em seguida calculou-se a taxa média desses indicadores no período estudado.

A estrutura média de custos e despesas das empresas pesquisadas, bem como as taxas médias dos indicadores de desempenho associados, podem ser observadas nas Tabelas 8 e 9, em que a primeira coluna representa a identificação das empresas; a segunda, a média de CDF no período de 2005 a 2009; a terceira coluna representa a média de CDV; e as quarta e quinta colunas representam as médias de MO e RO no período.

Tabela 8 - Estrutura de custo e despesa e MO/RO do Têxtil

\begin{tabular}{|c|c|c|c|c|}
\hline EMPRESA & $\begin{array}{c}\text { Média } \\
\text { CDF }\end{array}$ & $\begin{array}{c}\text { Média } \\
\text { CDV }\end{array}$ & $\begin{array}{c}\text { Média } \\
\text { MO }\end{array}$ & $\begin{array}{c}\text { Média } \\
\text { RO }\end{array}$ \\
\hline 1 & $20,56 \%$ & $79,44 \%$ & $13,75 \%$ & $15,98 \%$ \\
\hline 2 & $24,00 \%$ & $76,00 \%$ & $-57,36 \%$ & $-13,10 \%$ \\
\hline 3 & $21,80 \%$ & $78,20 \%$ & $-7,34 \%$ & $-5,19 \%$ \\
\hline 4 & $21,31 \%$ & $78,69 \%$ & $0,90 \%$ & $1,03 \%$ \\
\hline 5 & $21,17 \%$ & $78,83 \%$ & $3,22 \%$ & $3,81 \%$ \\
\hline 6 & $20,15 \%$ & $79,85 \%$ & $18,21 \%$ & $13,92 \%$ \\
\hline 7 & $21,01 \%$ & $78,99 \%$ & $5,69 \%$ & $6,76 \%$ \\
\hline 8 & $21,70 \%$ & $78,30 \%$ & $-4,99 \%$ & $-3,38 \%$ \\
\hline 9 & $22,07 \%$ & $77,93 \%$ & $-10,35 \%$ & $-4,78 \%$ \\
\hline 10 & $20,54 \%$ & $79,46 \%$ & $13,83 \%$ & $12,06 \%$ \\
\hline 11 & $20,78 \%$ & $79,22 \%$ & $8,75 \%$ & $6,46 \%$ \\
\hline 12 & $21,05 \%$ & $78,95 \%$ & $5,15 \%$ & $6,05 \%$ \\
\hline 13 & $21,02 \%$ & $78,98 \%$ & $5,30 \%$ & $3,99 \%$ \\
\hline 14 & $20,48 \%$ & $79,52 \%$ & $13,11 \%$ & $13,77 \%$ \\
\hline 15 & $23,75 \%$ & $76,25 \%$ & $-46,76 \%$ & $-72,62 \%$ \\
\hline 16 & $23,19 \%$ & $76,81 \%$ & $-27,98 \%$ & $-8,36 \%$ \\
\hline 17 & $22,30 \%$ & $77,70 \%$ & $-15,94 \%$ & $-9,24 \%$ \\
\hline 18 & $20,54 \%$ & $79,46 \%$ & $11,13 \%$ & $10,18 \%$ \\
\hline 19 & $20,76 \%$ & $79,24 \%$ & $10,49 \%$ & $12,04 \%$ \\
\hline Média Geral & $\mathbf{2 1 , 4 8 \%}$ & $\mathbf{7 8 , 5 2 \%}$ & $\mathbf{- 3 , 2 2 \%}$ & $\mathbf{- 0 , 5 6 \%}$ \\
\hline & & & & \\
\hline
\end{tabular}


Tabela 9 - Estrutura de custo e despesa e MO/RO da Siderurgia/Metalurgia

\begin{tabular}{|c|c|c|c|c|}
\hline EMPRESA & $\begin{array}{c}\text { Média } \\
\text { CDF }\end{array}$ & $\begin{array}{c}\text { Média } \\
\text { CDV }\end{array}$ & $\begin{array}{c}\text { Média } \\
\text { MO }\end{array}$ & $\begin{array}{c}\text { Média } \\
\text { RO }\end{array}$ \\
\hline 1 & $30,59 \%$ & $69,41 \%$ & $14,72 \%$ & $22,84 \%$ \\
\hline 2 & $32,16 \%$ & $67,84 \%$ & $-11,24 \%$ & $-3,76 \%$ \\
\hline 3 & $30,34 \%$ & $69,66 \%$ & $21,52 \%$ & $25,59 \%$ \\
\hline 4 & $30,35 \%$ & $69,65 \%$ & $18,24 \%$ & $16,39 \%$ \\
\hline 5 & $30,78 \%$ & $69,22 \%$ & $11,57 \%$ & $18,44 \%$ \\
\hline 6 & $30,35 \%$ & $69,65 \%$ & $19,50 \%$ & $16,06 \%$ \\
\hline 7 & $31,21 \%$ & $68,79 \%$ & $4,31 \%$ & $5,78 \%$ \\
\hline 8 & $31,79 \%$ & $68,21 \%$ & $-5,85 \%$ & $-1,77 \%$ \\
\hline 9 & $31,25 \%$ & $68,75 \%$ & $4,28 \%$ & $4,24 \%$ \\
\hline 10 & $31,94 \%$ & $68,06 \%$ & $-7,37 \%$ & $-7,51 \%$ \\
\hline 11 & $30,56 \%$ & $69,44 \%$ & $15,26 \%$ & $25,39 \%$ \\
\hline 12 & $31,25 \%$ & $68,75 \%$ & $4,70 \%$ & $8,74 \%$ \\
\hline 13 & $31,80 \%$ & $68,20 \%$ & $-6,48 \%$ & $-2,22 \%$ \\
\hline 14 & $30,60 \%$ & $69,40 \%$ & $14,52 \%$ & $12,35 \%$ \\
\hline Média Geral & $\mathbf{3 1 , 0 7 \%}$ & $\mathbf{6 8 , 9 3 \%}$ & $\mathbf{6 , 9 8 \%}$ & $\mathbf{1 0 , 0 4 \%}$ \\
\hline
\end{tabular}

Da análise preliminar das tabelas pode-se observar que no setor de Siderurgia/Metalurgia, em média, os indicadores de desempenho são maiores do que a média das empresas do setor Têxtil e a estrutura de custo e despesa é diferente. Tal observação sugere que as empresas do setor de Siderurgia/Metalurgia, em média, possuem maior economia de escala.

O que se pode afirmar a partir da estimação da função custo dos dois setores é que ambos possuem retornos decrescentes de escala. Os retornos de escalas são determinados pelos coeficientes angulares $\left(\beta_{1}, \beta_{2}, \beta_{n}\right)$ das funções, quando a soma é igual a um, os retornos de escalas são constantes, quando a soma é maior do que um, há retornos crescentes e quando a soma é menor do que um, retornos decrescentes (GUJARATI, 2006, p. 180).

$$
L N C D T_{\text {textil }}=(2,602)+(0,786 x \text { LNREC })
$$

Equação 9 - Função custo média do setor Têxtil

$$
L N C D T_{\text {sider/matal }}=[2,385+(0,124 \times L N M M O B)]+(0,685 \times L N R E C)
$$

Equação 10 - Função custo média do setor Siderurgia/Metalurgia

Os coeficientes angulares demonstram as elasticidades das variáveis, por exemplo, dado um aumento de \$1.000 na variável LNREC das empresas do setor Têxtil, em média, provocará um acréscimo de \$786 nos LNCDT. A elasticidade da variável LNREC é menor no setor de 
Siderurgia/Metalurgia, ou seja, nesse setor quando há aumento de receitas, em média, os custos e despesas aumentam menos do que no setor Têxtil.

Da análise das funções dos setores também se percebe que, no setor Siderurgia/Metalurgia, o componente de CDF é formado pelo intercepto individual mais a parcela de variação do IMOB, enquanto que, no setor Têxtil, o componente de CDF é formado exclusivamente pelo intercepto individual das empresas, isso ocorre porque a variável LNIMOB não foi estatisticamente significativa para o modelo do setor Têxtil.

Para analisar e discutir a relação entre a estrutura de custo e despesa e desempenho (medido aqui com base nos indicadores MO e RO), foi realizada uma separação em grupos de empresas nos dois setores, contendo um grupo para as empresas com indicadores de desempenho negativo, ou seja, com MO e RO menor que zero, denominado Grupo C, e as empresas com desempenho positivo foram divididas em: grupos de empresas com desempenho acima, Grupo A, e abaixo, Grupo B, da média no período.

As empresas dos Grupos A e B nos dois setores podem ser observadas nas Tabelas 10 a 15 .

Tabela 10 - Grupo A do Têxtil

\begin{tabular}{|c|c|c|c|c|}
\hline EMPRESA & $\begin{array}{c}\text { Média } \\
\text { CDF }\end{array}$ & $\begin{array}{c}\text { Média } \\
\text { CDV }\end{array}$ & $\begin{array}{c}\text { Média } \\
\text { MO }\end{array}$ & $\begin{array}{c}\text { Média } \\
\text { RO }\end{array}$ \\
\hline 1 & $20,56 \%$ & $79,44 \%$ & $13,75 \%$ & $15,98 \%$ \\
\hline 6 & $20,15 \%$ & $79,85 \%$ & $18,21 \%$ & $13,92 \%$ \\
\hline 10 & $20,54 \%$ & $79,46 \%$ & $13,83 \%$ & $12,06 \%$ \\
\hline 14 & $20,48 \%$ & $79,52 \%$ & $13,11 \%$ & $13,77 \%$ \\
\hline 18 & $20,54 \%$ & $79,46 \%$ & $11,13 \%$ & $10,18 \%$ \\
\hline 19 & $20,76 \%$ & $79,24 \%$ & $10,49 \%$ & $12,04 \%$ \\
\hline
\end{tabular}

Tabela 11 - Grupo B do Têxtil

\begin{tabular}{|c|c|c|c|c|}
\hline EMPRESA & $\begin{array}{c}\text { Média } \\
\text { CDF }\end{array}$ & $\begin{array}{c}\text { Média } \\
\text { CDV }\end{array}$ & $\begin{array}{c}\text { Média } \\
\text { MO }\end{array}$ & $\begin{array}{c}\text { Média } \\
\text { RO }\end{array}$ \\
\hline 4 & $21,31 \%$ & $78,69 \%$ & $0,90 \%$ & $1,03 \%$ \\
\hline 5 & $21,17 \%$ & $78,83 \%$ & $3,22 \%$ & $3,81 \%$ \\
\hline 7 & $21,01 \%$ & $78,99 \%$ & $5,69 \%$ & $6,76 \%$ \\
\hline 11 & $20,78 \%$ & $79,22 \%$ & $8,75 \%$ & $6,46 \%$ \\
\hline 12 & $21,05 \%$ & $78,95 \%$ & $5,15 \%$ & $6,05 \%$ \\
\hline 13 & $21,02 \%$ & $78,98 \%$ & $5,30 \%$ & $3,99 \%$ \\
\hline
\end{tabular}


Tabela 12 - Grupo C do Têxtil

\begin{tabular}{|c|c|c|c|c|}
\hline EMPRESA & $\begin{array}{c}\text { Média } \\
\text { CDF }\end{array}$ & $\begin{array}{c}\text { Média } \\
\text { CDV }\end{array}$ & $\begin{array}{c}\text { Média } \\
\text { MO }\end{array}$ & $\begin{array}{c}\text { Média } \\
\text { RO }\end{array}$ \\
\hline 2 & $24,00 \%$ & $76,00 \%$ & $-57,36 \%$ & $-13,10 \%$ \\
\hline 3 & $21,80 \%$ & $78,20 \%$ & $-7,34 \%$ & $-5,19 \%$ \\
\hline 8 & $21,70 \%$ & $78,30 \%$ & $-4,99 \%$ & $-3,38 \%$ \\
\hline 9 & $22,07 \%$ & $77,93 \%$ & $-10,35 \%$ & $-4,78 \%$ \\
\hline 15 & $23,75 \%$ & $76,25 \%$ & $-46,76 \%$ & $-72,62 \%$ \\
\hline 16 & $23,19 \%$ & $76,81 \%$ & $-27,98 \%$ & $-8,36 \%$ \\
\hline 17 & $22,30 \%$ & $77,70 \%$ & $-15,94 \%$ & $-9,24 \%$ \\
\hline
\end{tabular}

Tabela 13 - Grupo A da Siderurgia/Metalurgia

\begin{tabular}{|c|c|c|c|c|}
\hline EMPRESA & $\begin{array}{c}\text { Média } \\
\text { CDF }\end{array}$ & $\begin{array}{c}\text { Média } \\
\text { CDV }\end{array}$ & $\begin{array}{c}\text { Média } \\
\text { MO }\end{array}$ & $\begin{array}{c}\text { Média } \\
\text { RO }\end{array}$ \\
\hline 1 & $30,59 \%$ & $69,41 \%$ & $14,72 \%$ & $22,84 \%$ \\
\hline 3 & $30,34 \%$ & $69,66 \%$ & $21,52 \%$ & $25,59 \%$ \\
\hline 4 & $30,35 \%$ & $69,65 \%$ & $18,24 \%$ & $16,39 \%$ \\
\hline 6 & $30,35 \%$ & $69,65 \%$ & $19,50 \%$ & $16,06 \%$ \\
\hline 11 & $30,56 \%$ & $69,44 \%$ & $15,26 \%$ & $25,39 \%$ \\
\hline 14 & $30,60 \%$ & $69,40 \%$ & $14,52 \%$ & $12,35 \%$ \\
\hline
\end{tabular}

Tabela 14 - Grupo B da Siderurgia/Metalurgia

\begin{tabular}{|c|c|c|c|c|}
\hline EMPRESA & $\begin{array}{c}\text { Média } \\
\text { CDF }\end{array}$ & $\begin{array}{c}\text { Média } \\
\text { CDV }\end{array}$ & $\begin{array}{c}\text { Média } \\
\text { MO }\end{array}$ & $\begin{array}{c}\text { Média } \\
\text { RO }\end{array}$ \\
\hline 5 & $30,78 \%$ & $69,22 \%$ & $11,57 \%$ & $18,44 \%$ \\
\hline 7 & $31,21 \%$ & $68,79 \%$ & $4,31 \%$ & $5,78 \%$ \\
\hline 9 & $31,25 \%$ & $68,75 \%$ & $4,28 \%$ & $4,24 \%$ \\
\hline 12 & $31,25 \%$ & $68,75 \%$ & $4,70 \%$ & $8,74 \%$ \\
\hline
\end{tabular}

Tabela 15 - Grupo C da Siderurgia/Metalurgia

\begin{tabular}{|c|c|c|c|c|}
\hline EMPRESA & $\begin{array}{c}\text { Média } \\
\text { CDF }\end{array}$ & $\begin{array}{c}\text { Média } \\
\text { CDV }\end{array}$ & $\begin{array}{c}\text { Média } \\
\text { MO }\end{array}$ & $\begin{array}{c}\text { Média } \\
\text { RO }\end{array}$ \\
\hline 2 & $32,16 \%$ & $67,84 \%$ & $-11,24 \%$ & $-3,76 \%$ \\
\hline 8 & $31,79 \%$ & $68,21 \%$ & $-5,85 \%$ & $-1,77 \%$ \\
\hline 10 & $31,94 \%$ & $68,06 \%$ & $-7,37 \%$ & $-7,51 \%$ \\
\hline 13 & $31,80 \%$ & $68,20 \%$ & $-6,48 \%$ & $-2,22 \%$ \\
\hline
\end{tabular}

\subsection{Limitações}

Como todo modelo, a utilização do método de dados em painel também apresenta suas limitações. Gujarati (2006, p. 525) cita o problema da heterocedasticidade, que afeta os dados do corte transversal, e o problema da autocorrelação, que está relacionado às séries temporais. Além desses problemas, o autor cita, ainda, que há problemas adicionais, como a correlação 
cruzada de unidades individuais no mesmo ponto do tempo. Esses pressupostos do modelo econométrico foram testados e os resultados são comentados a seguir.

Segundo Stock e Watson (2004, p. 84), o problema da heterocedasticidade da distribuição dos resíduos ocorre quando a variância do termo de erro que é gerado pelo modelo está condicionada às variáveis explicativas utilizadas no modelo. Segundo Doane e Seward (2008, p. 587), uma possível consequência do problema da heterocedasticidade é a perda de eficiência dos parâmetros da regressão e de seu poder preditivo. Já o problema da autocorrelação ocorre quando um erro está correlacionado com o erro do período anterior (GUJARATI, 2006, p. 358). Sobre a autocorrelação, Doane e Seward (2008, p. 588) explicam que esse problema provoca o estreitamento do intervalo de confiança da regressão.

Para verificar o pressuposto da homogeneidade dos resíduos, os resíduos individuais dos dois setores foram gerados e foi utilizado o teste de Levene, conforme Quadros 4 e 5.

O teste de Levene de ambos os setores indica que a distribuição dos resíduos gerados segue um padrão heterocedástico, sendo a probabilidade do teste inferior a $5 \%$, indicando que não há evidências para aceitar a hipótese nula de que os resíduos são distribuídos homogeneamente. Apesar da violação desse pressuposto, ele não rejeita a validade do modelo (DOANE; SEWARD, 2008, p. 588).

Quadro 4 - Teste de Levene: setor Têxtil

\begin{tabular}{|ll|r|r|r|r|}
\hline & \multicolumn{1}{|c|}{$\begin{array}{l}\text { Levene } \\
\text { Statistic }\end{array}$} & \multicolumn{1}{c|}{ df1 } & \multicolumn{1}{c|}{ df2 } & \multicolumn{1}{c|}{ Sig. } \\
\hline Residuos & Based on Mean & 3,657 & 20 & 84 &, 000 \\
& Based on Median & 1,163 & 20 & 84 &, 307 \\
& Based on Median and with & 1,163 & 20 & 15,951 &, 384 \\
& adjusted df & & & & \\
& Based on trimmed mean & 3,102 & 20 & 84 &, 000 \\
\hline
\end{tabular}

Quadro 5 - Teste de Levene: setor Siderúrgico/Metalúrgico

\begin{tabular}{|ll|r|r|r|r|}
\hline & & \multicolumn{1}{c|}{$\begin{array}{l}\text { Levene } \\
\text { Statistic }\end{array}$} & df1 & df2 & \multicolumn{1}{c|}{ Sig. } \\
\hline Residuos & Based on Mean & 2,462 & 16 & 68 &, 005 \\
& Based on Median & 1,081 & 16 & 68 &, 390 \\
& Based on Median and & 1,081 & 16 & 20,240 &, 428 \\
& with adjusted df & & & \\
& Based on trimmed mean & 2,062 & 16 & 68 &, 021 \\
\hline
\end{tabular}


Já para verificar a existência de autocorrelação nos resíduos gerados pelo modelo utiliza-se o teste de Durbin-Watson (GUJARATI, 2006, p. 359). Doane e Seward (2008, p. 588) explicam que a estatística desse teste encontra-se em um intervalo entre 0 e 4 . Quanto mais próximo do centro, ou seja, do valor igual a 2, menor a probabilidade de existência de autocorrelação. Para ambos os setores, o valor da estatística Durbin-Watson ficou relativamente próximo de 2, indicando ausência de autocorrelação. Conforme demonstra o Apêndice 3, o valor do teste foi 1,33 para o setor Têxtil e 2,31 para o setor de Siderurgia/Metalurgia.

Guajarati (2006, p. 526) explica que tanto o problema da heterocedasticidade das variâncias dos resíduos quanto a autocorrelação podem ser tratados com base na aplicação de duas técnicas mais comuns: (1) o modelo de efeitos fixos; e (2) o modelo de efeitos aleatórios. $\mathrm{O}$ autor comenta ainda que "[...] no modelo de efeitos fixos, o intercepto do modelo de regressão pode diferir entre indivíduos para levar em conta o fato de que cada unidade individual ou de corte transversal pode ter algumas características especiais."

Além da homocedasticidade e da autocorrelação dos resíduos deve-se testar o pressuposto da normalidade nos resíduos gerados pelo modelo. Mais uma vez, os resíduos foram gerados e o teste de Kolmogorov-Smirnov foi realizado individualmente. A grande maioria dos resíduos apresentou distribuição do tipo normal, tanto para as empresas do setor Têxtil quando do setor de Siderurgia/Metalurgia, uma vez que o valor "Sig." dos textes é superior a 5\% $(0,05)$, sugerindo a aceitação de Ho de que a distribuição dos resíduos segue um padrão normal, conforme pode ser observado nas Tabelas 16 e 17. 
Tabela 16 - Teste de normalidade dos resíduos para o setor Têxtil

\begin{tabular}{|c|c|c|c|c|c|c|}
\hline \multirow{2}{*}{ empresa } & \multicolumn{2}{|c|}{ Kolmogorov-Smirnov } & \multicolumn{3}{c|}{ Shapiro-Wilk } \\
\cline { 2 - 7 } & Statistic & $\mathrm{df}$ & Sig. & Statistic & $\mathrm{df}$ & Sig. \\
\hline 1 & 0,24 & 5,00 & 0,20 & 0,93 & 5,00 & 0,61 \\
\hline 2 & 0,28 & 5,00 & 0,20 & 0,78 & 5,00 & 0,06 \\
\hline 3 & 0,39 & 5,00 & 0,01 & 0,71 & 5,00 & 0,01 \\
\hline 4 & 0,33 & 5,00 & 0,08 & 0,81 & 5,00 & 0,09 \\
\hline 5 & 0,18 & 5,00 & 0,20 & 0,97 & 5,00 & 0,87 \\
\hline 6 & 0,22 & 5,00 & 0,20 & 0,97 & 5,00 & 0,84 \\
\hline 7 & 0,17 & 5,00 & 0,20 & 0,98 & 5,00 & 0,93 \\
\hline 8 & 0,29 & 5,00 & 0,20 & 0,86 & 5,00 & 0,22 \\
\hline 9 & 0,18 & 5,00 & 0,20 & 0,97 & 5,00 & 0,86 \\
\hline 10 & 0,38 & 5,00 & 0,02 & 0,73 & 5,00 & 0,02 \\
\hline 11 & 0,26 & 5,00 & 0,20 & 0,89 & 5,00 & 0,35 \\
\hline 12 & 0,18 & 5,00 & 0,20 & 0,98 & 5,00 & 0,93 \\
\hline 13 & 0,20 & 5,00 & 0,20 & 0,95 & 5,00 & 0,73 \\
\hline 14 & 0,40 & 5,00 & 0,01 & 0,71 & 5,00 & 0,01 \\
\hline 15 & 0,46 & 5,00 & 0,00 & 0,57 & 5,00 & 0,00 \\
\hline 16 & 0,29 & 5,00 & 0,20 & 0,84 & 5,00 & 0,18 \\
\hline 17 & 0,26 & 5,00 & 0,20 & 0,92 & 5,00 & 0,56 \\
\hline 18 & 0,22 & 5,00 & 0,20 & 0,95 & 5,00 & 0,73 \\
\hline 19 & 0,14 & 5,00 & 0,20 & 0,99 & 5,00 & 0,98 \\
\hline
\end{tabular}

Tabela 17 - Teste de normalidade dos resíduos para o setor de Siderurgia/Metalurgia

\begin{tabular}{|c|c|c|c|c|c|c|}
\hline \multirow{2}{*}{ Empresa } & \multicolumn{2}{|c|}{ Kolmogorov-Smirnov } & \multicolumn{3}{c|}{ Shapiro-Wilk } \\
\cline { 2 - 7 } & Statistic & df & Sig. & Statistic & df & Sig. \\
\hline 1 & 0,20 & 5,00 & 0,20 & 0,95 & 5,00 & 0,76 \\
\hline 2 & 0,18 & 5,00 & 0,20 & 0,95 & 5,00 & 0,71 \\
\hline 3 & 0,30 & 5,00 & 0,17 & 0,79 & 5,00 & 0,06 \\
\hline 4 & 0,29 & 5,00 & 0,20 & 0,83 & 5,00 & 0,15 \\
\hline 5 & 0,22 & 5,00 & 0,20 & 0,92 & 5,00 & 0,53 \\
\hline 6 & 0,22 & 5,00 & 0,20 & 0,92 & 5,00 & 0,53 \\
\hline 7 & 0,25 & 5,00 & 0,20 & 0,89 & 5,00 & 0,36 \\
\hline 8 & 0,22 & 5,00 & 0,20 & 0,88 & 5,00 & 0,32 \\
\hline 9 & 0,34 & 5,00 & 0,07 & 0,80 & 5,00 & 0,08 \\
\hline 10 & 0,35 & 5,00 & 0,04 & 0,79 & 5,00 & 0,06 \\
\hline 11 & 0,28 & 5,00 & 0,20 & 0,89 & 5,00 & 0,36 \\
\hline 12 & 0,25 & 5,00 & 0,20 & 0,85 & 5,00 & 0,18 \\
\hline 13 & 0,21 & 5,00 & 0,20 & 0,94 & 5,00 & 0,66 \\
\hline 14 & 0,19 & 5,00 & 0,20 & 0,96 & 5,00 & 0,79 \\
\hline
\end{tabular}

O último pressuposto testado foi quanto à ausência de multicolinearidade, ou seja, ausência de correlação perfeita (quando a correlação é igual a 1) entre as variáveis explicativas nos dois modelos gerados. Contudo, na maior parte dos trabalhos aplicados as ciências sociais é quase impossível encontrar duas ou mais variáveis (econômicas) que não sejam correlacionadas até certo ponto (GUJARATI, 2006, p. 165). Para verificar a existência de correlação entre as 
variáveis explicativas, foi construída e analisada a matriz de correlação das variáveis dos dois modelos, conforme o Quadro 6. Esse pressuposto não foi testado para o setor Têxtil, porque o modelo possui apenas uma variável explicativa (LNREC).

Quadro 6 - Matriz de correlação entre variáveis do modelo: Siderurgia/Metalurgia

\begin{tabular}{|c|c|c|}
\hline & LNREC & LNIMOB \\
\hline LNREC & 1,0000 & \\
\hline LNIMOB & 0,7418 & 1,0000 \\
\hline
\end{tabular}

A correlação entre as variáveis explicativas LNREC e LNIMOB no setor de Siderurgia/Metalurgia é alta (acima de 70\%). No entanto, como essa correlação ainda é menor do que o coeficiente de correlação múltipla do modelo que é 0,99 (ver Apêndice 4), suportado pela Regra de Klein, não encontram-se evidências para rejeitar esse pressuposto.

Correlação significante entre preditores não são indicativos per se de um problema sério. A Regra de Klein sugere que devamos nos preocupar com a estabilidade das estimativas dos coeficientes da regressão somente quando a correlação de um par de preditores excede o coeficiente de correlação múltipla (DOANE; SEWARD, 2008, p. 582, grifos nossos).

Embora com algumas limitações, o modelo econométrico atende a um dos objetivos propostos nesta tese que é estimar com os dados do passado a função que exprime a estrutura de custos e despesas de empresas de dois setores distintos, em um determinado período. Foram tomados os cuidados recomendados por Gujarati (2006, p. 441) para manter no modelo apenas as variáveis estatisticamente significativas.

Outra limitação diz respeito à heterogeneidade das empresas. Embora tenha sido estimada a função custo de um grupo de empresas de um mesmo setor, há certa heterogeneidade no grupo de empresas dos modelos, tanto do setor Têxtil, quanto Siderúrgico/Metalúrgico, porque suas atividades principais não são necessariamente as mesmas. No entanto, a metodologia de dados em painel resolve parte desse problema ao capturar no intercepto as diferenças de características das empresas ao estimar a função custo individual.

A pesquisa demonstra uma metodologia para estimar estrutura de custos de empresas com utilização de dados disponíveis publicamente, entretanto, em um próximo estágio da pesquisa, é recomendável a verificação empírica com os gestores dessas empresas, ou mesmo com empresas de outros setores, para confirmação das estimativas. 


\section{ANÁLISE DOS RESULTADOS}

Inicialmente as análises foram realizadas individualmente em cada setor e, depois, comparados os resultados entre os dois setores. A análise individual tem início com uma breve descrição das principais características do setor para auxiliar na interpretação dos dados. Também se julgou necessária a análise do contexto econômico do período (2005 a 2009) para ajudar a compreender possíveis mudanças no padrão de desempenho das empresas nos setores pesquisados. Tal análise foi baseada no panorama descrito pelo Relatório Anual do Boletim Banco Central do Brasil, disponível no website dessa instituição.

\subsection{Cenário econômico no Brasil e no mundo no período estudado}

Neste item o objetivo é traçar um resumo do panorama dos principais acontecimentos da economia brasileira e mundial no período estudado, com base nos relatórios econômicos consolidados do Banco Central do Brasil (BACEN), com o objetivo de que essas informações possam subsidiar o processo de análise e interpretação dos resultados da pesquisa.

\subsubsection{Ano de 2005}

O cenário macroeconômico do Brasil no ano de 2005 foi marcado por dois períodos distintos. No primeiro semestre, o Comitê de Política Monetária (COPOM) promoveu gradativa elevação da taxa Selic, chegando a 19,75\% a.a. em maio; tal política foi motivada por pressões inflacionárias causadas pela elevação dos preços do petróleo no mercado internacional. No entanto, a partir do segundo semestre de 2005, o governo reverteu a tendência de alta da taxa de juros, o que aumentou a confiança dos consumidores e contribuiu para um crescimento sustentado da economia nacional impulsionada pelo mercado interno (BACEN, 2005, p. 12).

\subsubsection{Ano de 2006}

Em 2006, o cenário econômico mundial era de franca expansão, embalado, principalmente, pelo desempenho dos Estados Unidos. Nesse contexto, o governo brasileiro aproveitou o 
momento favorável e a estabilidade dos preços para realizar ajustes na política de juros, reduzindo a taxa Selic em 4,75 pontos percentuais ao longo do ano. Esse cenário provocou aquecimento ainda maior da demanda interna e culminou na expansão do crédito, favorecendo, principalmente, os setores de construção civil e de bens de capital (BACEN, 2006, p. 11-12).

\subsubsection{Ano de 2007}

O ano de 2007 foi marcado pela interrupção da expansão econômica mundial, desencadeada pela crise no mercado subprime dos Estados Unidos, levando ao risco de uma crise em todo sistema financeiro mundial. No Brasil, o primeiro semestre do ano foi de crescimento e de consolidação das políticas macroeconômicas, o que levou as agências de classificação de risco a reduzirem o risco do país aos menores níveis históricos; no entanto, a crise financeira mundial no segundo semestre fez com que as principais agências elevassem o risco do Brasil novamente, deixando o país em um nível abaixo do grau de investimento (BACEN, 2007, p. 12 e 14).

\subsubsection{Ano de 2008}

O cenário econômico mundial no ano de 2008 foi marcado pela intensificação da recessão em mercados maduros, obrigando os bancos centrais, os governos dos Estados Unidos e de países europeus a ações coordenadas junto ao sistema financeiro de seus países na tentativa de mitigar os efeitos da crise de crédito sobre o nível de atividade. No caso da economia brasileira, os efeitos foram sentidos principalmente no último trimestre do ano, obrigando o governo a anunciar medidas fiscais para o ano seguinte, mas o bom desempenho nos três primeiros trimestres do ano sustentou o crescimento do Produto Interno Bruto (PIB) daquele ano em 5,1\% (BACEN, 2008, p. 11-12).

\subsubsection{Ano de 2009}

Até a metade do segundo trimestre o mundo seguia em um cenário de crise e escassez de crédito; porém, a partir do segundo semestre, as medidas de política governamental começaram a surtir efeitos, reaquecendo a economia mundial e, em alguns países, revertendo o cenário recessivo. No caso brasileiro, as medidas se iniciaram em 2008, que incluíam ajustes na esfera fiscal, principalmente com base na desoneração, com ênfase na isenção ou 
redução do Imposto sobre Produtos Industrializados (IPI) para alguns setores, visando assegurar o nível de emprego. A recuperação da economia brasileira foi novamente sustentada pelo dinamismo da demanda interna. Em um primeiro momento, a reação foi mais percebida nos segmentos produtores de bens de menor valor agregado e, em seguida, a recuperação também passou para os segmentos de maior valor agregado e bens de capital (BACEN, 2009, p. 11-12).

\subsubsection{Reflexo do cenário econômico nos setores estudados}

Diversos fatores devem ter influenciado o comportamento do nível de atividade e o desempenho econômico-financeiro dos dois setores estudados, tais como a taxa de juros, o volume e o montante de importações e de exportações, a taxa de câmbio, a taxa de inflação etc., mas não é o objetivo principal discutir os fatores condicionantes da estrutura de custos e despesas, nem modelos de negócios e direcionadores de resultados específicos para cada setor.

Apesar de não estar dentro do objetivo, nesta parte da tese faz-se uma breve discussão das características da taxa de juros em relação ao crescimento ou diminuição do volume de negócios, conforme mostram os Gráficos 1 e 2.

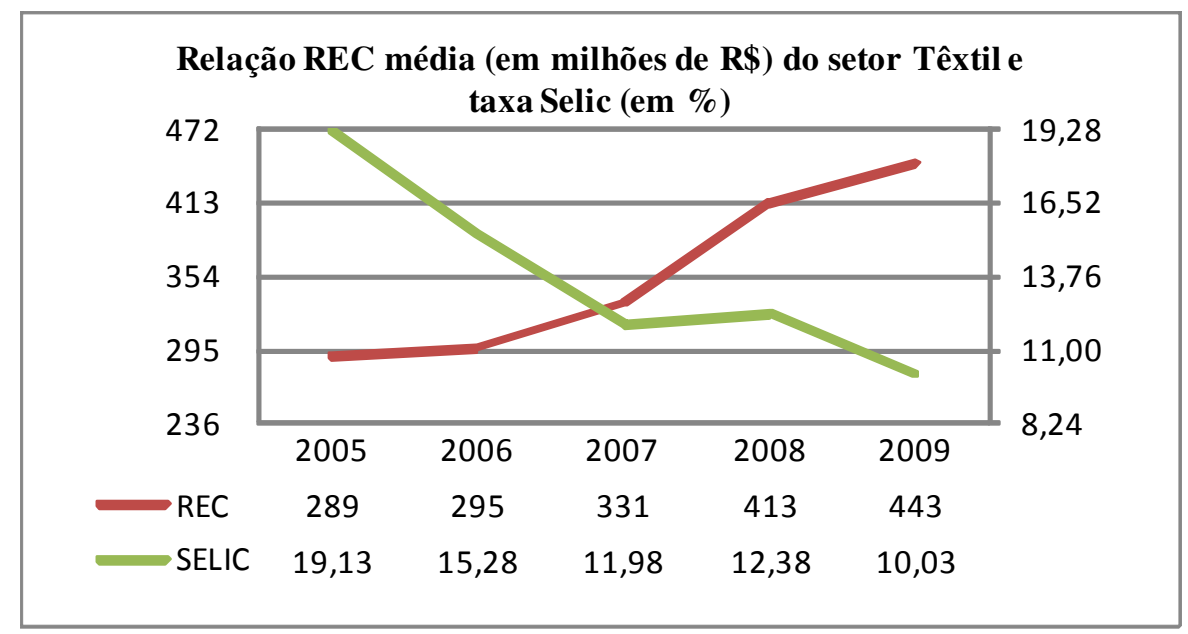

Gráfico 1 - Receitas líquidas médias das empresas do Têxtil e Selic média FONTE: Economática e Banco Central do Brasil

No caso do setor Têxtil, a sensibilidade à taxa de juros é maior porque o mercado interno representa a maior parcela da receita das empresas desse setor; a produção é fundamentalmente pautada no mercado interno, sendo que menos de $3 \%$ é destinada ao mercado externo (FLEURY et al, 2007, p. 133-143). Percebe-se pelo Gráfico 1 que a 
diminuição da taxa Selic durante os anos de 2005 a 2009 propiciou o aumento do consumo interno, mantendo a receita das empresas estudadas desse setor em um crescimento constante durante todo o período.

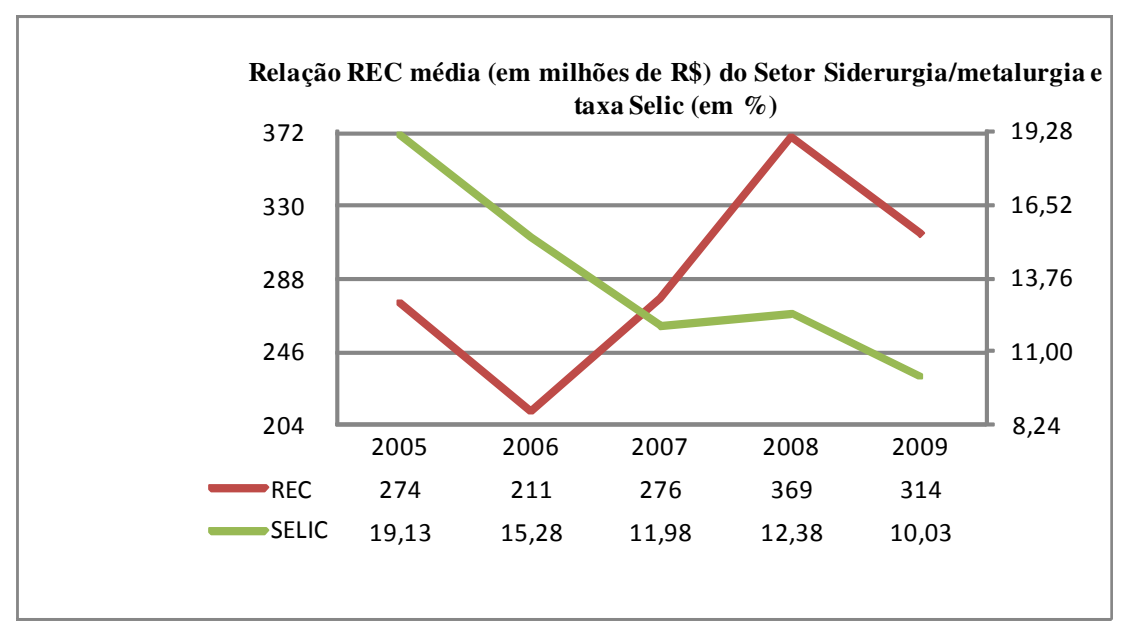

Gráfico 2 - Receitas líquidas médias das empresas da Siderurgia/Metalurgia e Selic média FONTE: Economática e Banco Central do Brasil

O setor Siderurgia/Metalurgia também é influenciado nesse mesmo sentido, pois tem empresas que fazem parte da indústria do aço e que tem como principais clientes as empresas de indústria de bens duráveis e de construção civil dentro do mercado interno (VITAL; PINTO, 2009, p. 45); porém, nesse setor há uma parcela considerável da produção que se destina ao mercado externo e que, portanto, sofre influência de outros fatores, como a variação cambial e a economia externa. Observa-se no Gráfico 2, em 2005, a maior taxa Selic do período estudado nesta tese; consequentemente, o ano seguinte para o setor Siderurgia/Metalurgia foi o de menor faturamento. Em 2006, com a redução gradativa da taxa de juros, as receitas foram crescendo, somente interrompidas em 2009 devido à redução de crédito causada pela crise financeira.

Uma outra análise pode ser feita relacionando-se a conclusão da pesquisa de Mauer e Ott (1995) com as informações do cenário econômico e o Gráfico 3. Os autores provam que, em cenários de maior incerteza, os gestores optam por uma estrutura de custo preponderantemente variável; consequentemente, as empresas tendem a reduzir os CDF nesse cenário. 

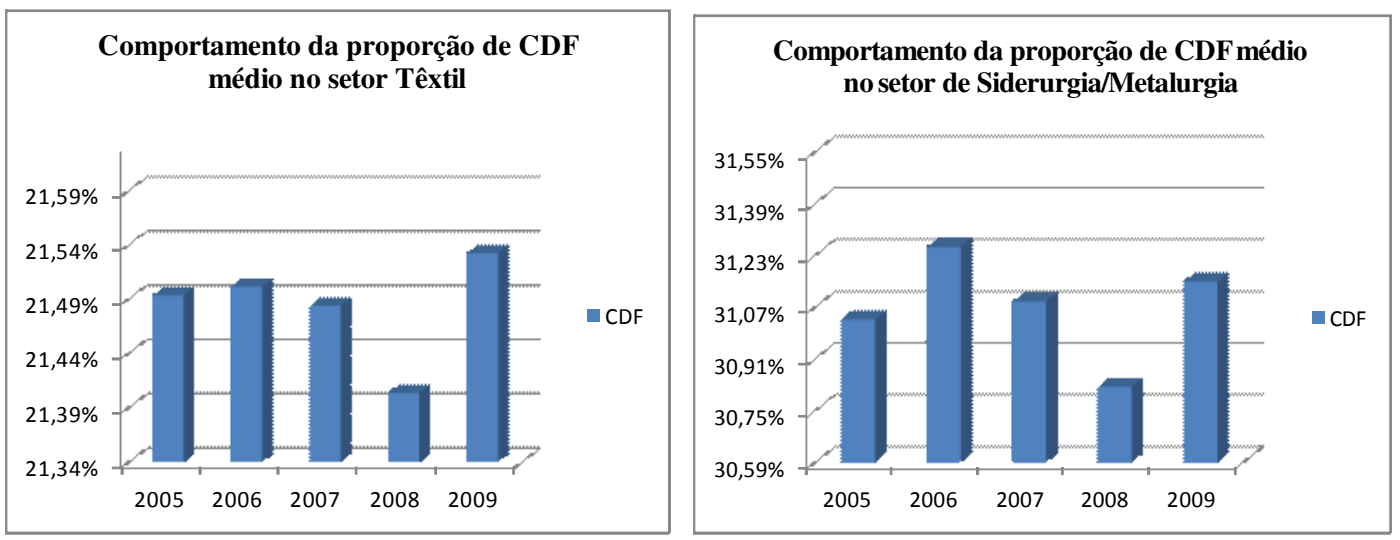

Gráfico 3 - Evolução do CDF médio das empresas por setor

De acordo com a análise do cenário econômico do período, o ano de maior grau de incerteza foi o de 2008, devido a reflexos da crise financeira mundial iniciada no segundo semestre do ano anterior. Com base na estimativa da participação média dos CDF nos dois setores, observa-se que a participação média dos CDF foi menor exatamente no ano de 2008, parecendo corroborar com a pesquisa feita por Mauer e Ott (1995) de que as empresas tendem a reduzir custos fixos em períodos de incerteza.

\subsection{Têxtil}

O objetivo deste item é fornecer algumas informações básicas relativas às características inerentes ao setor Têxtil, com base nas entidades representativas das empresas desse setor, bem como em trabalhos anteriores que o abordaram como tema central.

\subsubsection{Informações do setor}

O setor Têxtil brasileiro destaca-se por sua importância econômica e histórica no desenvolvimento da indústria brasileira e paulistana. Segundo Teixeira (2007, p. 68), na década de 1930, o setor empregava dois terços dos trabalhadores da indústria de transformação de São Paulo. Entretanto, no início da década de 1990, com a abertura comercial e a concorrência com produtos importados, houve o fechamento de grandes empresas e redução de 35\% nos empregos deste setor (HUMBERG, 2004, p. 151). 
Nesse cenário, o governo federal decidiu ajudar as empresas do setor por meio da liberação de linhas de financiamento do BNDES e promovendo a redução das alíquotas de impostos para aquisição de equipamentos novos, levando à modernização das instalações e ao aumento da produtividade em torno de 43\% (PADILHA, 2009, p. 86).

Uma das características do setor Têxtil mundial é a busca por redução de custos de mão de obra. Padilha (2009, p. 91) explica que as grandes cadeias instalam plantas em países periféricos, onde as legislações sociais e ambientais são mais brandas. Vieira (1995) concluiu que a preocupação com a capacitação da mão de obra não é exatamente uma prioridade do setor.

Segundo Fleury et al (2007, p. 133-143), o setor Têxtil brasileiro está voltado prioritariamente para o mercado interno (menos de $3 \%$ da produção nacional é destinada à exportação); porém, algumas empresas do setor já buscam a internacionalização com aquisição de empresas estrangeiras e abertura de escritórios em países para onde a exportação é mais significativa, como Estados Unidos e Argentina. Os autores explicam ainda que esse movimento das empresas brasileiras faz parte da estratégia para gerar ganhos de escala e tornar os preços competitivos no mercado interno e internacional e o "novo alvo" dessas empresas é a China, onde a mão de obra é barata, o mercado interno é muito grande e está próximo de outros mercados consumidores, como o Japão.

Segundo relatório divulgado pela Agência Brasileira de Desenvolvimento Industrial (ABDI, 2010), a indústria Têxtil do Brasil está em expansão e o objetivo é ganhar destaque no mercado internacional. O texto sobre a "visão de futuro" construído por integrantes do setor inicia-se com a seguinte passagem: "Ser competitiva globalmente e exportadora de destaque [...]" (ABDI, 2010, p. 52).

\subsubsection{Análise dos dados da amostra de empresas do setor}

Para realizar a análise e interpretação da relação entre a estrutura de custo e despesa e os indicadores de desempenho das empresas do setor Têxtil, a partir dos dados estimados e observados, separaram-se dois grupos de empresas: com desempenho negativo (MO e RO médios menores do que zero) e positivo (MO e RO médios maiores do que zero). 
As empresas do grupo com MO e RO negativos foram classificadas como Grupo C. Esse grupo foi criado porque nesta tese considerou-se que a manutenção de lucratividade e rentabilidade abaixo de zero por um período de tempo pode colocar em dúvida até mesmo a continuidade do negócio. A Tabela 18 demonstra dados das empresas do grupo C.

Tabela 18 - Grupo C do setor Têxtil: MO e RO negativos

\begin{tabular}{|c|r|r|r|r|}
\hline EMPRESAS & Média CDF & Média CDV & Média MO & Média RO \\
\hline 2 & $24,00 \%$ & $76,00 \%$ & $-57,36 \%$ & $-13,10 \%$ \\
\hline 3 & $21,80 \%$ & $78,20 \%$ & $-7,34 \%$ & $-5,19 \%$ \\
\hline 8 & $21,70 \%$ & $78,30 \%$ & $-4,99 \%$ & $-3,38 \%$ \\
\hline 9 & $22,07 \%$ & $77,93 \%$ & $-10,35 \%$ & $-4,78 \%$ \\
\hline 15 & $23,75 \%$ & $76,25 \%$ & $-46,76 \%$ & $-72,62 \%$ \\
\hline 16 & $23,19 \%$ & $76,81 \%$ & $-27,98 \%$ & $-8,36 \%$ \\
\hline 17 & $22,30 \%$ & $77,70 \%$ & $-15,94 \%$ & $-9,24 \%$ \\
\hline Média Geral & $\mathbf{2 2 , 6 9 \%}$ & $\mathbf{7 7 , 3 1 \%}$ & $\mathbf{- 2 4 , 3 9 \%}$ & $\mathbf{- 1 6 , 6 7 \%}$ \\
\hline
\end{tabular}

Somente a Tabela 18 tem uma coluna de média de CDV, para comprovar que a soma da média de CDF com a média de CDV resulta em $100 \%$. As próximas tabelas terão somente a coluna da média de CDF; para calcular o percentual de CDV basta subtrair o valor da média de CDF de $100 \%$.

Na Tabela 19 estão listadas as empresas que apresentaram MO e RO positivos no período.

Tabela 19 - Empresas do setor Têxtil com indicadores MO e RO positivos

\begin{tabular}{|c|r|r|r|}
\hline EMPRESAS & \multicolumn{1}{|c|}{$\begin{array}{c}\text { Média } \\
\text { CDF }\end{array}$} & $\begin{array}{c}\text { Média } \\
\text { MO }\end{array}$ & \multicolumn{1}{c|}{$\begin{array}{c}\text { Média } \\
\text { RO }\end{array}$} \\
\hline 1 & $20,56 \%$ & $13,75 \%$ & $15,98 \%$ \\
\hline 4 & $21,31 \%$ & $0,90 \%$ & $1,03 \%$ \\
\hline 5 & $21,17 \%$ & $3,22 \%$ & $3,81 \%$ \\
\hline 6 & $20,15 \%$ & $18,21 \%$ & $13,92 \%$ \\
\hline 7 & $21,01 \%$ & $5,69 \%$ & $6,76 \%$ \\
\hline 10 & $20,54 \%$ & $13,83 \%$ & $12,06 \%$ \\
\hline 11 & $20,78 \%$ & $8,75 \%$ & $6,46 \%$ \\
\hline 12 & $21,05 \%$ & $5,15 \%$ & $6,05 \%$ \\
\hline 13 & $21,02 \%$ & $5,30 \%$ & $3,99 \%$ \\
\hline 14 & $20,48 \%$ & $13,11 \%$ & $13,77 \%$ \\
\hline 18 & $20,54 \%$ & $11,13 \%$ & $10,18 \%$ \\
\hline 19 & $20,76 \%$ & $10,49 \%$ & $12,04 \%$ \\
\hline Média Geral & $\mathbf{2 0 , 7 8 \%}$ & $\mathbf{9 , 1 3 \%}$ & $\mathbf{8 , 8 4 \%}$ \\
\hline
\end{tabular}

É importante destacar que há um percetual de proporção do nível de custo e despesa fixa entre as empresas com indicadores positivos $(20,78 \%$ de CDF) e indicadores negativos $(22,69 \%$ de 
CDF). Não há evidências suficientes para afirmar que foi a estrutura que provocou o desempenho, mas, sem dúvidas, essa informação deve ser levada em consideração pelos gestores.

Com base, agora, apenas nas empresas com indicadores positivos, extraíram-se novamente as médias de CDF, MO e RO. Verificou-se, dentre essas empresas, quais apresentavam ambos os indicadores de desempenho acima e abaixo da média. Essas empresas foram separadas em dois grupos: Grupo A, as empresas com ambos indicadores, MO e RO, acima da média, e Grupo B com pelo menos um dos indicadores abaixo da média. As Tabelas 20 e 21 demonstram os dados das empresas pertencentes a cada grupo.

Tabela 20 - Grupo A do setor Têxtil: MO e RO acima da média

\begin{tabular}{|c|c|c|c|}
\hline EMPRESAS & $\begin{array}{c}\text { Média } \\
\text { CDF }\end{array}$ & $\begin{array}{c}\text { Média } \\
\text { MO }\end{array}$ & $\begin{array}{c}\text { Média } \\
\text { RO }\end{array}$ \\
\hline 1 & $20,56 \%$ & $13,75 \%$ & $15,98 \%$ \\
\hline 6 & $20,15 \%$ & $18,21 \%$ & $13,92 \%$ \\
\hline 10 & $20,54 \%$ & $13,83 \%$ & $12,06 \%$ \\
\hline 14 & $20,48 \%$ & $13,11 \%$ & $13,77 \%$ \\
\hline 18 & $20,54 \%$ & $11,13 \%$ & $10,18 \%$ \\
\hline 19 & $20,76 \%$ & $10,49 \%$ & $12,04 \%$ \\
\hline Média Geral & $\mathbf{2 0 , 5 1 \%}$ & $\mathbf{1 3 , 4 2 \%}$ & $\mathbf{1 2 , 9 9 \%}$ \\
\hline
\end{tabular}

Tabela 21 - Grupo B do setor Têxtil: MO ou RO abaixo da média

\begin{tabular}{|c|c|c|c|}
\hline EMPRESAS & $\begin{array}{c}\text { Média } \\
\text { CDF }\end{array}$ & $\begin{array}{c}\text { Média } \\
\text { MO }\end{array}$ & $\begin{array}{c}\text { Média } \\
\text { RO }\end{array}$ \\
\hline 4 & $21,31 \%$ & $0,90 \%$ & $1,03 \%$ \\
\hline 5 & $21,17 \%$ & $3,22 \%$ & $3,81 \%$ \\
\hline 7 & $21,01 \%$ & $5,69 \%$ & $6,76 \%$ \\
\hline 11 & $20,78 \%$ & $8,75 \%$ & $6,46 \%$ \\
\hline 12 & $21,05 \%$ & $5,15 \%$ & $6,05 \%$ \\
\hline 13 & $21,02 \%$ & $5,30 \%$ & $3,99 \%$ \\
\hline Média Geral & $\mathbf{2 1 , 0 6 \%}$ & $\mathbf{4 , 8 4 \%}$ & $\mathbf{4 , 6 8 \%}$ \\
\hline
\end{tabular}

A partir da separação das empresas nesses grupos, buscou-se estudar o comportamento dos grupos com base nos indicadores extraídos das demonstrações contábeis disponíveis publicamente.

A construção desses indicadores levou em consideração a média de receita líquida (REC) das empresas, a proporção média dos custos e despesas totais (CDT) em relação às REC e a proporção média do ativo imobilizado (Imobilizado) em relação às REC, pois essas foram as 
variáveis utilizadas no modelo. Adicionalmente, estudou-se a proporção média dos estoques (Estoques) em relação às REC ao final de cada período, devido a essa conta incorporar ao Balanço Patrimonial parte dos custos fixos e variáveis dos produtos, os que foram produzidos mas não vendidos no mesmo período.

Os resultados médios das empresas pertencentes aos grupos A, B e C são demonstrados nas Tabelas 22, 23 e 24. A tabela completa, ano a ano, dos indicadores de cada grupo de empresas do setor Têxtil pode ser observada nos Apêndices 5 e 6.

Tabela 22 - Grupo A do Têxtil: indicadores

\begin{tabular}{|l|r|r|r|r|r|r|r|}
\hline \multicolumn{1}{|c|}{ Indicador } & $\mathbf{2 0 0 5}$ & \multicolumn{1}{c|}{$\mathbf{2 0 0 6}$} & \multicolumn{1}{c|}{$\mathbf{2 0 0 7}$} & \multicolumn{1}{c|}{$\mathbf{2 0 0 8}$} & \multicolumn{1}{c|}{$\mathbf{2 0 0 9}$} & \multicolumn{1}{c|}{ Média } & \multicolumn{1}{c|}{$\begin{array}{c}\text { Cresc. } \\
\text { Médio }\end{array}$} \\
\hline REC (em milR\$) & 565,54 & 588,95 & 695,63 & 914,33 & 1019,94 & 756,88 & $16,31 \%$ \\
\hline CDT / REC & 0,83 & 0,88 & 0,88 & 0,85 & 0,88 & 0,87 & $1,62 \%$ \\
\hline Estoque / REC & 0,12 & 0,13 & 0,14 & 0,14 & 0,15 & 0,13 & $5,84 \%$ \\
\hline Imobilizado / REC & 0,40 & 0,39 & 0,36 & 0,28 & 0,30 & 0,35 & $-7,02 \%$ \\
\hline MO & $16,82 \%$ & $12,26 \%$ & $11,60 \%$ & $14,89 \%$ & $11,52 \%$ & $13,42 \%$ & \\
\hline RO & $16,40 \%$ & $12,19 \%$ & $10,42 \%$ & $14,39 \%$ & $11,55 \%$ & $12,99 \%$ & \\
\hline
\end{tabular}

Tabela 23 - Grupo B do Têxtil: indicadores

\begin{tabular}{|l|r|r|r|r|r|r|r|}
\hline \multicolumn{1}{|c|}{ Indicador } & $\mathbf{2 0 0 5}$ & $\mathbf{2 0 0 6}$ & \multicolumn{1}{c|}{$\mathbf{2 0 0 7}$} & \multicolumn{1}{c|}{$\mathbf{2 0 0 8}$} & \multicolumn{1}{c|}{$\mathbf{2 0 0 9}$} & \multicolumn{1}{c|}{ Média } & \multicolumn{1}{c|}{$\begin{array}{c}\text { Cresc. } \\
\text { Médio }\end{array}$} \\
\hline REC (em milR\$) & 207,05 & 209,48 & 221,91 & 258,34 & 261,47 & 231,65 & $6,18 \%$ \\
\hline CDT / REC & 0,93 & 0,98 & 0,93 & 0,95 & 0,97 & 0,95 & $1,22 \%$ \\
\hline Estoque / REC & 0,23 & 0,21 & 0,20 & 0,23 & 0,21 & 0,21 & $-1,37 \%$ \\
\hline Imobilizado / REC & 0,38 & 0,37 & 0,36 & 0,42 & 0,39 & 0,38 & $1,45 \%$ \\
\hline MO & $7,20 \%$ & $1,95 \%$ & $7,20 \%$ & $4,93 \%$ & $2,90 \%$ & $4,84 \%$ & \\
\hline RO & $8,51 \%$ & $1,31 \%$ & $6,66 \%$ & $5,13 \%$ & $1,80 \%$ & $4,68 \%$ & \\
\hline
\end{tabular}

Tabela 24 - Grupo C do Têxtil: indicadores

\begin{tabular}{|l|r|r|r|r|r|r|r|}
\hline \multicolumn{1}{|c|}{ Indicador } & $\mathbf{2 0 0 5}$ & $\mathbf{2 0 0 6}$ & \multicolumn{1}{c|}{$\mathbf{2 0 0 7}$} & \multicolumn{1}{c|}{$\mathbf{2 0 0 8}$} & \multicolumn{1}{c|}{$\mathbf{2 0 0 9}$} & \multicolumn{1}{c|}{ Média } & $\begin{array}{l}\text { Cresc. } \\
\text { Médio }\end{array}$ \\
\hline REC (em milR\$) & 121,76 & 117,68 & 112,53 & 114,52 & 105,07 & 114,31 & $-3,55 \%$ \\
\hline CDT / REC & 1,09 & 1,07 & 1,11 & 1,21 & 1,74 & 1,24 & $13,57 \%$ \\
\hline Estoque / REC & 0,19 & 0,22 & 0,22 & 0,22 & 0,17 & 0,20 & $-1,88 \%$ \\
\hline Imobilizado / REC & 0,79 & 0,82 & 0,89 & 0,91 & 1,33 & 0,95 & $15,18 \%$ \\
\hline MO & $-9,41 \%$ & $-6,77 \%$ & $-10,95 \%$ & $-20,94 \%$ & $-73,87 \%$ & $-24,39 \%$ & \\
\hline RO & $-4,88 \%$ & $-3,69 \%$ & $-5,83 \%$ & $-8,67 \%$ & $-60,26 \%$ & $-16,67 \%$ & \\
\hline
\end{tabular}

Inicialmente, chama a atenção que a REC média do Grupo A é mais de três vezes maior que a do grupo B e mais de seis vezes maior do que a do Grupo C. No entanto, cabe lembrar que esse é um indicador médio e, conforme pode ser observado no Apêndice 5, existem empresas 
com receita menor que fazem parte do grupo A (empresas 6, 14 e 18). Portanto, o fato de a organização ter o faturamento maior ou menor não garante que tenha um desempenho acima da média, confirmando a hipótese de Penrose (2006, p. 40) de que não existe tamanho ótimo ou mais lucrativo para as empresas, e que a gestão deve adequar a estrutura de acordo com o porte da organização.

Percebeu-se também que a taxa média de crescimento de REC das empresas do Grupo A é mais do que o dobro do crescimento das do Grupo B, demonstrando que a manutenção dos indicadores de desempenho acima da média no período foi sustentado por forte crescimento de receitas, provavelmente reflexo do aquecimento do mercado interno.

Quanto ao indicador CDT/REC, a média do Grupo A no período ficou em 0, 87, enquanto que a do Grupo B em 0,95, demonstrando que a diferença é pequena, mas determinante para que o primeiro tivesse MO acima da média. A média de crescimento desse indicador também é semelhante entre os Grupos A e B, sendo que o crescimento do segundo foi ligeiramente menor, mostrando que o indicador deste grupo aproximou-se do primeiro, no período.

O comportamento do indicador CDT/REC médio das empresas do Grupo C foi maior que um, ou seja, os CDT superam as REC $(1,24)$, mas o fator que mais chama a atenção é que o indicador dessas empresas cresceu em média $13,57 \%$ no período, demonstrando que o crescimento dos CDT foi maior do que o crescimento das REC no período analisado, piorando cada vez mais a situação das empresas desse grupo.

O indicador Estoque/REC demonstra que a proporção de estoques das empresas do Grupo A é menor do que as do Grupo B, porém a taxa de crescimento desse indicador é positivo para as empresas do primeiro grupo e negativo para as do segundo. Para que esse indicador apresente elevação, o crescimento do saldo médio dos estoques deve ser superior ao do saldo médio das receitas; constatou-se que há aumento de estoques no período analisado para os dois grupos. A proporção de estoques sobre REC das empresas do Grupo C foi 0,20, portanto maior do que as do Grupo A, consequentemente, sugere maior gasto em CDF (armazenagem).

Quanto ao indicador Imobilizado/REC, observa-se que as empresas do Grupo A tem a menor proporção e que houve redução desse indicador no período, demonstrando que as empresas desse grupo foram as que menos investiram nesse tipo de ativo em proporção à receita. No 
Grupo B houve pequeno crescimento (1,45\%). Já no Grupo C, observa-se que a proporção de ativo imobilizado é o mais alto dos três grupos, outro indício de maior investimento em CDF (depreciação) das empresas desse grupo no período analisado, comparativamente à receita.

Os indicadores de desempenho MO e RO foram as variáveis que discriminaram as empresas de cada um dos grupos. Pela análise da média geral dos indicadores percebe-se que as maiores empresas (pelo critério de tamanho da REC) são também as que tiveram MO e RO acima da média e que essas empresas apresentaram uma redução do indicador imobilizado/REC e um aumento do indicador estoques/REC, provavelmente devido ao movimento de crescimento das receitas, sustentado pela expansão da demanda e do consumo interno observados no período.

Na etapa seguinte de análise foram utilizados apenas os dados das empresas dos Grupos A e B (MO e RO positivos) para comparar o desempenho observado com a estrutura de custo e despesa estimada.

Para se analisar e interpretar a relação entre a estrutura de custos e despesas das empresas e seus indicadores de desempenho econômico foi realizado um estudo do comportamento dos $\mathrm{CDF}$ estimados pelo modelo econométrico em relação à margem operacional $(\mathrm{MO})$ e ao retorno operacional (RO) com base na construção de dois gráficos de dispersão, com adição da linha de tendência. No Gráfico 4, os eixos se cruzam no ponto médio das variáveis: 20,78\% para CDF e 9,13\% para MO. O mesmo ocorre no Gráfico 5, em que o ponto médio de RO é $8,84 \%$.

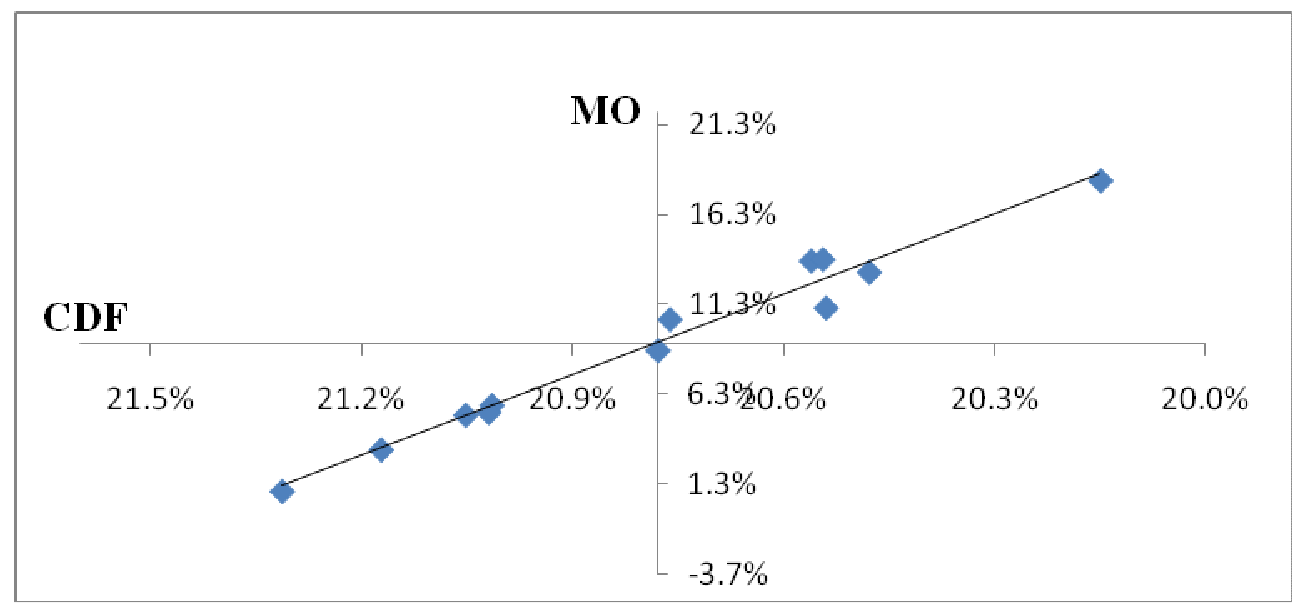

Gráfico 4 - Relação entre CDF e MO no setor Têxtil: 2005 a 2009 (Grupos A e B) 


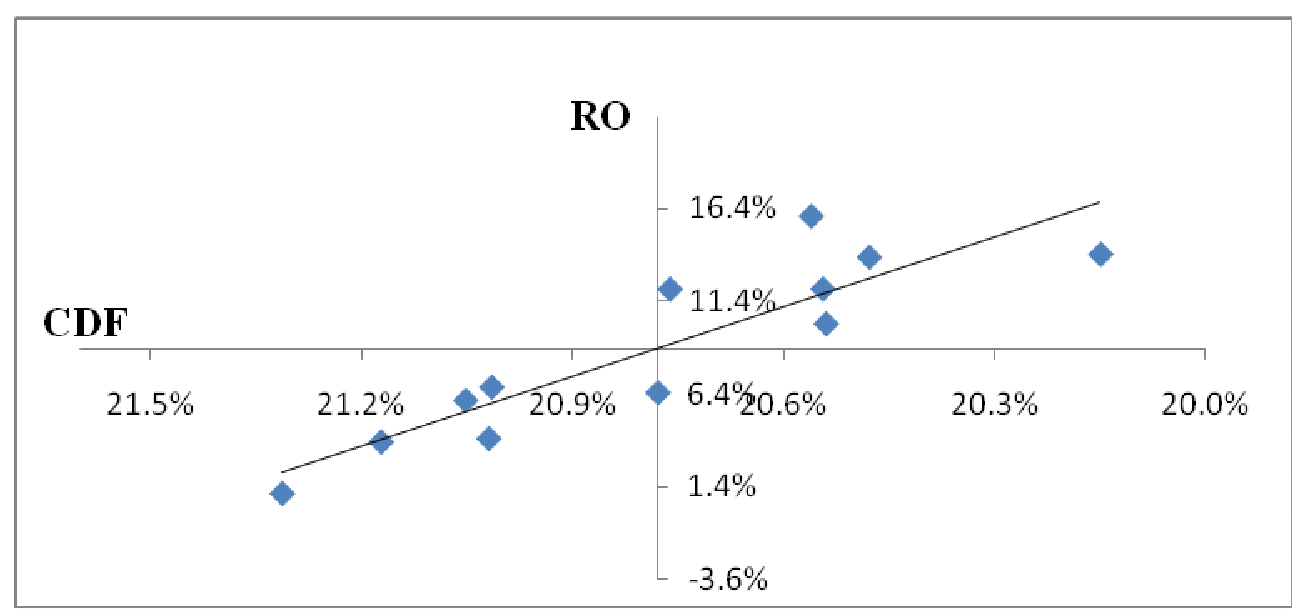

Gráfico 5 - Relação entre CDF e RO no setor Têxtil: 2005 a 2009 (Grupos A e B)

Pode-se observar, nos Gráficos 4 e 5, que a maioria das observações concentra-se em apenas dois quadrantes, demonstrando a separação entre os grupos A e B. No quadrante direito e acima, encontram-se as empresas com CDF abaixo da média e indicadores MO e RO acima da média, enquanto que, no quadrante esquerdo e abaixo, estão as empresas com CDF acima da média e indicadores abaixo da média.

A análise visual dos gráficos demonstra claramente que existe correlação forte e negativa entre o percentual de CDF e os indicadores de desempenho (MO e RO); porém, percebe-se que a correlação é mais acentuada para MO do que para RO. Para confirmar essa impressão visual e quantificar essa correlação calculou-se o coeficiente de correlação entre essas variáveis. Os resultados são observados no Quadro 7.

\section{Quadro 7 - Correlação entre CDF com MO e CDF com RO no Têxtil (Grupos A e B)}

\begin{tabular}{|c|c|}
\hline Correl (CDF; MO) & $-98,69 \%$ \\
\hline Correl (CDF; RO) & $-89,07 \%$ \\
\hline
\end{tabular}

Para identificar a relação entre estrutura de custo e despesa com os indicadores de desempenho verificaram-se os pontos médio, máximo e mínimo de CDF das empresas que apresentam indicadores de desempenho acima e abaixo da média, bem como das empresas com indicadores negativos (MO e RO abaixo de zero). A ideia foi construir uma área delimitando o percentual de CDF das empresas que obtiveram MO e RO negativos e positivos (acima e abaixo da média do setor) no período investigado, a fim de que se pudesse visualizar o intervalo em que a estrutura de custo de cada grupo de empresas variou. 
Quadro 8 - Relação de CDF com MO e RO no Têxtil: 2005 a 2009

\begin{tabular}{|c|c|c|c|c|c|c|}
\hline & $\begin{array}{c}\text { c/ MO } \\
\text { acima }\end{array}$ & $\begin{array}{c}\text { c/ MO } \\
\text { Abaixo }\end{array}$ & $\begin{array}{c}\text { c/ RO } \\
\text { acima }\end{array}$ & $\begin{array}{c}\text { c/ RO } \\
\text { ABAIXO }\end{array}$ & $\begin{array}{c}\text { c/ MO } \\
\text { Negativa }\end{array}$ & $\begin{array}{c}\text { c/ RO } \\
\text { Negativo }\end{array}$ \\
\hline Mínimo & $20,15 \%$ & $20,78 \%$ & $20,15 \%$ & $20,78 \%$ & $21,70 \%$ & $21,70 \%$ \\
\hline Máximo & $20,76 \%$ & $21,31 \%$ & $20,76 \%$ & $21,31 \%$ & $24,00 \%$ & $24,00 \%$ \\
\hline
\end{tabular}

Com base nas informações do Quadro 8, pode-se construir a análise dos intervalos de estrutura de CDF das empresas com desempenho observado negativo, acima e abaixo da média, conforme a Ilustração 3.

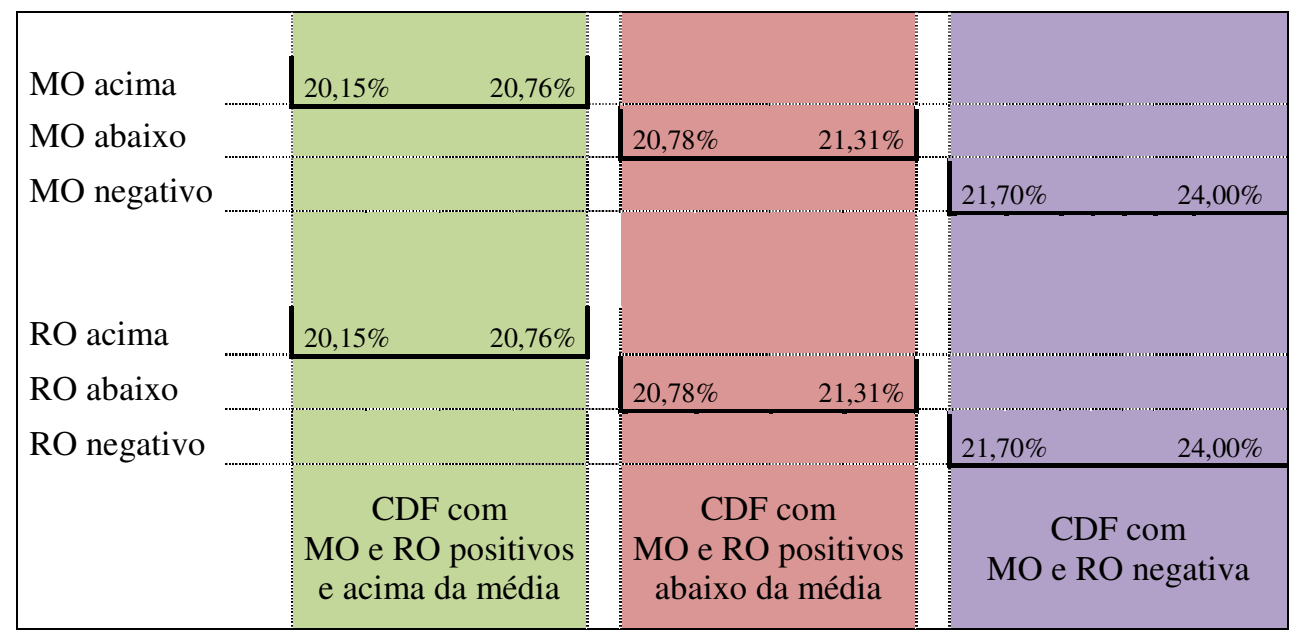

Ilustração 3 - Intervalo de CDF com MO/RO: Têxtil

Verifica-se, portanto, que as empresas do setor Têxtil que apresentaram desempenho observado acima da média no período analisado estão na primeira área da figura, em que a proporção de CDF está no intervalo entre $20,15 \%$ e 20,76\% dos custos e despesas totais.

As empresas que apresentaram desempenho positivo, porém abaixo da média no período analisado, estão na segunda área da figura, em que a proporção de CDF está no intervalo entre $20,78 \%$ e $21,31 \%$ dos custos e despesas totais.

As empresas com desempenho negativo apresentaram a maior participação de CDF dos três grupos, no intervalo entre $21,70 \%$ e $24,00 \%$.

Apesar de a análise oferecer um retrato do comportamento da estrutura de custos e despesas das empresas do setor Têxtil no período de 2005 a 2009, não se pode afirmar de forma determinística que a manutenção da proporção de CDF nos intervalos 20,15\% a 20,76\% é 
suficiente para alcançar desempenho acima da média do setor Têxtil. Por outro lado, a análise contribui para oferecer aos gestores das empresas desse setor um panorama do comportamento da estrutura de custo e despesas com relação ao desempenho, possibilitando uma comparabilidade, podendo auxiliar nas estratégias a serem definidas.

\subsection{Siderurgia/Metalurgia}

Este item inicia-se com uma breve caracterização das atividades inerentes ao setor de Siderurgia/Metalurgia, baseada em informações obtidas de entidades representativas do setor e em trabalhos anteriores que o abordaram como tema principal.

\subsubsection{Informações do setor}

As empresas do setor de Siderurgia/Metalurgia brasileiro que fizeram parte da pesquisa estão inseridas na indústria do aço. Segundo Vital e Pinto (2009, p. 45), o mercado do aço apresenta dois segmentos principais: (i) a produção de aços planos para o setor de bens de consumo duráveis e (ii) a produção de aços longos para o setor da construção civil. Vaz (2010, p. 12) acrescenta afirmando que outro segmento importante para a destinação do aço é a indústria de autopeças.

A Siderurgia/Metalurgia tem importância histórica no desenvolvimento da economia brasileira. Landgraf et al (1995) explicam que a vinda da família real portuguesa para o Brasil, no início do século XIX, impulsionou o nascimento da indústria do aço no país, porém, a partir de 1850, as empresas desse setor começaram a entrar em declínio em função de fatores como concorrência com produtos ingleses, escassez de mão de obra e priorização de outros produtos como açúcar e o café (INSTITUTO DO AÇO, 2009).

A indústria do aço brasileira ressurgiu no início do século XX (VAZ, 2010, p. 13) e ganhou força com a criação da Companhia Belgo Mineira (1925) e principalmente da Companhia Siderúrgica Nacional (1950) (INSTITUTO DO AÇO, 2009).

Na década de 1980, devido à retração do mercado interno, a indústria encontrou uma saída com a exportação (INSTITUTO DO AÇO, 2009). Na década de 1990, o principal destaque 
foi o movimento de desestatização e concentração no setor (VAZ, 2010, p. 17). Segundo o Instituto Aço Brasil (2009), no ano de 2009 havia, no país, 29 usinas siderúrgicas, que eram controladas por apenas nove grupos empresariais e, entre 1994 e 2007, foram realizados investimentos superiores a US\$20 bilhões, colocando o Brasil entre os maiores produtores mundiais de aço bruto. O Quadro 9 resume alguns dados do setor.

Quadro 9 - Dados relativos à indústria do aço (referentes ao ano de 2009)

\begin{tabular}{|c|c|}
\hline Parque produtor de aço: & $\begin{array}{l}28 \text { usinas, sendo que } 13 \text { integradas (a partir do minério de ferro) e } 15 \text { semi- } \\
\text { integradas (a partir do processo de ferro gusa com a sucata), administradas por } 9 \\
\text { grupos empresariais }\end{array}$ \\
\hline Capacidade instalada: & 42,1 milhões de t/ano de aço bruto \\
\hline Produção aço bruto: & 26,5 milhões de $\mathrm{t}$ \\
\hline Produtos siderúrgicos: & 25,7 milhões de $\mathrm{t}$ \\
\hline Consumo aparente: & 18,6 milhões de $\mathrm{t}$ \\
\hline $\begin{array}{l}\text { Número de } \\
\text { colaboradores: }\end{array}$ & 116.409 \\
\hline Saldo comercial: & US $\$ 1,9$ bilhões - 7,5\% do saldo comercial do país \\
\hline $\begin{array}{l}5^{\circ} \text { Maior exportador } \\
\text { líquido de aço (exp - imp): }\end{array}$ & 6,5 milhões de $t$ \\
\hline $\begin{array}{l}\text { Exportações indiretas } \\
\text { (aço contido em bens): }\end{array}$ & 2,1 milhões de $t$ \\
\hline $\begin{array}{l}\text { Consumo per capita de } \\
\text { aço no Brasil: }\end{array}$ & 97 quilos de aço bruto/habitante \\
\hline $\begin{array}{l}\text { Principais setores } \\
\text { consumidores de aço: }\end{array}$ & $\begin{array}{l}\text { Construção Civil; Automotivo; Bens de capital, Máquinas e Equipamentos } \\
\text { (incluindo Agrícolas); Utilidades Domésticas e Comerciais }\end{array}$ \\
\hline
\end{tabular}

FONTE: Instituto Aço Brasil (www.acobrasil.org.br)

\subsubsection{Análise dos dados da amostra de empresas do setor}

Para realizar a análise e interpretação da relação entre a estrutura de custo e despesa e os indicadores de desempenho das empresas do setor Siderurgia/Metalurgia, a partir dos dados estimados e observados, separaram-se dois grupos de empresas: com desempenho negativo (MO e RO médios menores do que zero) e positivo (MO e RO médios maiores do que zero).

As empresas do grupo com MO e RO negativos foram classificadas como Grupo C. Esse grupo foi criado, pois considerou-se, nesta tese, que a manutenção de lucratividade e 
rentabilidade abaixo de zero por um período de tempo pode colocar em dúvida até a continuidade do negócio. A Tabela 25 demonstra o Grupo C.

Tabela 25 - Grupo C da Siderurgia/Metalurgia: MO e RO negativos

\begin{tabular}{|c|r|r|r|}
\hline EMPRESA & Média CDF & Média MO & Média RO \\
\hline 2 & $32,16 \%$ & $-11,24 \%$ & $-3,76 \%$ \\
\hline 8 & $31,79 \%$ & $-5,85 \%$ & $-1,77 \%$ \\
\hline 10 & $31,94 \%$ & $-7,37 \%$ & $-7,51 \%$ \\
\hline 13 & $31,80 \%$ & $-6,48 \%$ & $-2,22 \%$ \\
\hline Média Geral & $\mathbf{3 1 , 9 2 \%}$ & $\mathbf{- 7 , 7 4 \%}$ & $\mathbf{- 3 , 8 2 \%}$ \\
\hline
\end{tabular}

Na Tabela 26 estão listadas as empresas que apresentaram MO e RO positivos no período.

Tabela 26 - Empresas do setor Siderurgia/Metalurgia com indicadores MO e RO positivos

\begin{tabular}{|c|r|r|r|}
\hline EMPRESA & \multicolumn{1}{|c|}{$\begin{array}{c}\text { Média } \\
\text { CDF }\end{array}$} & $\begin{array}{c}\text { Média } \\
\text { MO }\end{array}$ & $\begin{array}{c}\text { Média } \\
\text { RO }\end{array}$ \\
\hline 1 & $30,59 \%$ & $14,72 \%$ & $22,84 \%$ \\
\hline 3 & $30,34 \%$ & $21,52 \%$ & $25,59 \%$ \\
\hline 4 & $30,35 \%$ & $18,24 \%$ & $16,39 \%$ \\
\hline 5 & $30,78 \%$ & $11,57 \%$ & $18,44 \%$ \\
\hline 6 & $30,35 \%$ & $19,50 \%$ & $16,06 \%$ \\
\hline 7 & $31,21 \%$ & $4,31 \%$ & $5,78 \%$ \\
\hline 9 & $31,25 \%$ & $4,28 \%$ & $4,24 \%$ \\
\hline 11 & $30,56 \%$ & $15,26 \%$ & $25,39 \%$ \\
\hline 12 & $31,25 \%$ & $4,70 \%$ & $8,74 \%$ \\
\hline 14 & $30,60 \%$ & $14,52 \%$ & $12,35 \%$ \\
\hline Média Geral & $\mathbf{3 0 , 7 3 \%}$ & $\mathbf{1 2 , 8 6 \%}$ & $\mathbf{1 5 , 5 8 \%}$ \\
\hline
\end{tabular}

É importante destacar que os cálculos demonstram que o nível de custo e despesa fixa entre as empresas com indicadores positivos é de $30,73 \%$ e das empresas com indicadores negativos é de 31,92\%. Não há evidências suficientes para afirmar que foi a estrutura que provocou o desempenho, mas, sem dúvidas, essa informação deve ser levada em consideração pelos gestores.

Com base, agora, apenas nas empresas com indicadores positivos, extraíram-se novamente as médias de CDF, MO e RO. Verificou-se, dentre essas empresas, quais apresentavam ambos os indicadores de desempenho acima e abaixo da média. Essas empresas foram separadas em dois grupos: Grupo A, as empresas com ambos indicadores, MO e RO, acima da média e Grupo B com pelo menos um dos indicadores abaixo da média. As Tabelas 27 e 28 demonstram as empresas pertencentes a cada grupo. 
Tabela 27 - Grupo A da Siderurgia/Metalurgia: MO e RO positivos e acima da média

\begin{tabular}{|c|r|r|r|}
\hline EMPRESA & Média CDF & Média MO & Média RO \\
\hline 1 & $30,59 \%$ & $14,72 \%$ & $22,84 \%$ \\
\hline 3 & $30,34 \%$ & $21,52 \%$ & $25,59 \%$ \\
\hline 4 & $30,35 \%$ & $18,24 \%$ & $16,39 \%$ \\
\hline 6 & $30,35 \%$ & $19,50 \%$ & $16,06 \%$ \\
\hline 11 & $30,56 \%$ & $15,26 \%$ & $25,39 \%$ \\
\hline 14 & $30,60 \%$ & $14,52 \%$ & $12,35 \%$ \\
\hline
\end{tabular}

Tabela 28 - Grupo B da Siderurgia/Metalurgia: MO e RO positivos, mas abaixo da média

\begin{tabular}{|c|r|r|r|}
\hline EMPRESA & Média CDF & Média MO & Média RO \\
\hline 5 & $30,78 \%$ & $11,57 \%$ & $18,44 \%$ \\
\hline 7 & $31,21 \%$ & $4,31 \%$ & $5,78 \%$ \\
\hline 9 & $31,25 \%$ & $4,28 \%$ & $4,24 \%$ \\
\hline 12 & $31,25 \%$ & $4,70 \%$ & $8,74 \%$ \\
\hline
\end{tabular}

Após essa análise inicial e a classificação das empresas em três grupos realizou-se análise do comportamento de indicadores contábeis do período, a fim de identificar e discutir as semelhanças e diferenças entre os grupos formados.

Os indicadores utilizados foram: receita líquida (REC); custos e despesas totais sobre a receita líquida (CDT/REC); valor contábil dos estoques sobre a receita líquida (Estoque/REC); valor contábil do ativo imobilizado sobre a receita líquida (Imobilizado/REC); além dos indicadores de desempenho: margem operacional (MO) e rentabilidade operacional (RO). Os saldos de CDT, Estoque e Imobilizado foram divididos pelo saldo de REC para padronizar e comparar as informações entre os grupos. O valor médio dos indicadores do período de 2005 a 2009 de cada grupo pode ser observado nas Tabelas 29, 30 e 31 e os dados completos da análise de cada grupo no período encontram-se no Apêndice 6.

Tabela 29 - Grupo A da Siderurgia/Metalurgia: indicadores

\begin{tabular}{|l|r|r|r|r|r|r|r|}
\hline \multicolumn{1}{c|}{ Indicador } & \multicolumn{1}{c|}{$\mathbf{2 0 0 5}$} & \multicolumn{1}{c|}{$\mathbf{2 0 0 6}$} & \multicolumn{1}{c|}{$\mathbf{2 0 0 7}$} & \multicolumn{1}{c|}{$\mathbf{2 0 0 8}$} & \multicolumn{1}{c|}{$\mathbf{2 0 0 9}$} & \multicolumn{1}{c|}{ Média } & \multicolumn{1}{c|}{$\begin{array}{c}\text { Cresc. } \\
\text { Médio }\end{array}$} \\
\hline REC (em milR\$) & 494,56 & 382,74 & 531,53 & 723,74 & 615,18 & 549,55 & $9,36 \%$ \\
\hline CDT / REC & 0,84 & 0,85 & 0,84 & 0,77 & 0,84 & 0,83 & $0,18 \%$ \\
\hline Estoque / REC & 0,21 & 0,25 & 0,23 & 0,24 & 0,20 & 0,23 & $-0,92 \%$ \\
\hline Imobilizado / REC & 0,25 & 0,27 & 0,25 & 0,21 & 0,31 & 0,26 & $8,96 \%$ \\
\hline MO & $15,99 \%$ & $14,71 \%$ & $16,18 \%$ & $23,49 \%$ & $16,10 \%$ & $17,29 \%$ & \\
\hline RO & $21,72 \%$ & $17,57 \%$ & $17,92 \%$ & $27,35 \%$ & $14,28 \%$ & $19,77 \%$ & \\
\hline
\end{tabular}


Tabela 30 - Grupo B da Siderurgia/Metalurgia: indicadores

\begin{tabular}{|l|r|r|r|r|r|r|r|}
\hline \multicolumn{1}{c|}{ Indicador } & \multicolumn{1}{c|}{$\mathbf{2 0 0 5}$} & $\mathbf{2 0 0 6}$ & \multicolumn{1}{c|}{$\mathbf{2 0 0 7}$} & \multicolumn{1}{c|}{$\mathbf{2 0 0 8}$} & \multicolumn{1}{c|}{$\mathbf{2 0 0 9}$} & \multicolumn{1}{c|}{ Média } & \multicolumn{1}{c|}{$\begin{array}{c}\text { Cresc. } \\
\text { Médio }\end{array}$} \\
\hline REC (em milR\$) & 111,06 & 107,46 & 124,58 & 151,59 & 134,66 & 125,87 & $5,80 \%$ \\
\hline CDT / REC & 0,94 & 0,95 & 0,91 & 0,94 & 0,95 & 0,94 & $0,55 \%$ \\
\hline Estoque / REC & 0,12 & 0,13 & 0,14 & 0,15 & 0,14 & 0,14 & $2,75 \%$ \\
\hline Imobilizado / REC & 0,25 & 0,26 & 0,25 & 0,39 & 0,43 & 0,32 & $15,77 \%$ \\
\hline MO & $6,41 \%$ & $4,90 \%$ & $9,42 \%$ & $5,78 \%$ & $4,55 \%$ & $6,21 \%$ & \\
\hline RO & $9,51 \%$ & $6,88 \%$ & $14,43 \%$ & $9,32 \%$ & $6,37 \%$ & $9,30 \%$ & \\
\hline
\end{tabular}

Tabela 31 - Grupo C da Siderurgia/Metalurgia: indicadores

\begin{tabular}{|l|r|r|r|r|r|r|r|}
\hline \multicolumn{1}{c|}{ Indicador } & \multicolumn{1}{c|}{$\mathbf{2 0 0 5}$} & \multicolumn{1}{c|}{$\mathbf{2 0 0 6}$} & \multicolumn{1}{c|}{$\mathbf{2 0 0 7}$} & \multicolumn{1}{c|}{$\mathbf{2 0 0 8}$} & \multicolumn{1}{c|}{$\mathbf{2 0 0 9}$} & \multicolumn{1}{c|}{ Média } & \multicolumn{1}{c|}{$\begin{array}{c}\text { Cresc. } \\
\text { Médio }\end{array}$} \\
\hline REC (em milR\$) & 172,30 & 110,25 & 111,43 & 145,09 & 119,57 & 131,73 & $-5,58 \%$ \\
\hline CDT / REC & 0,98 & 1,11 & 1,10 & 1,01 & 1,18 & 1,08 & $5,20 \%$ \\
\hline Estoque / REC & 0,34 & 0,38 & 0,34 & 0,29 & 0,34 & 0,34 & $0,63 \%$ \\
\hline Imobilizado / REC & 0,48 & 0,62 & 0,60 & 0,43 & 0,48 & 0,52 & $2,45 \%$ \\
\hline MO & $1,86 \%$ & $-11,00 \%$ & $-10,30 \%$ & $-1,24 \%$ & $-18,00 \%$ & $-7,74 \%$ & \\
\hline RO & $5,29 \%$ & $-4,63 \%$ & $-4,36 \%$ & $-1,54 \%$ & $-13,84 \%$ & $-3,82 \%$ & \\
\hline
\end{tabular}

Assim como ocorreu na análise do setor Têxtil, na Siderurgia/Metalurgia, o Grupo A tem, em média, as empresas com maior receita líquida; porém as receitas médias das empresas do Grupo C foram maiores do que as do Grupo B. As empresas do Grupo A tiveram receita líquida mais de quatro vezes maior do que as empresas dos Grupos B e C. Essa distância cresceu ainda mais no período porque o crescimento médio de REC das empresas do grupo A foi de $9,36 \%$ no período, enquanto que as vendas das empresas dos grupos B e C cresceram $5,80 \%$ e $-5,58 \%$, respectivamente.

O indicador CDT/REC das empresas do grupo A foi de 0,83 enquanto que, do grupo $\mathrm{B}$, foi de 0,94; no entanto, tanto as empresas do Grupo A quanto às do Grupo B conseguiram manter esse indicador praticamente estável no período (crescimento médio, 0,18\% para o Grupo A e 0,55\% para o Grupo B). Já para as empresas do grupo C, conforme esperado, em média, os CDT superam a REC em 8\% (indicador 1,08) e houve crescimento médio do indicador no período de 5, 20\%, no período, piorando ainda mais a situação desse grupo.

Quanto ao indicador Estoque/REC, a média é maior para as empresas do Grupo A $(0,23)$ do que para as empresas do Grupo B $(0,14)$, demonstrando que o primeiro grupo praticou uma proporção de níveis de estoques, em relação às receitas, maiores do que o segundo. 
O indicador Imobilizado/REC é menor para as empresas do Grupo A $(0,26)$ do que para as empresas do Grupo B $(0,32)$ e o crescimento médio do saldo de imobilizado sobre receitas líquidas foi $8,96 \%$ para o primeiro grupo e $15,77 \%$ para o segundo, evidenciando um maior crescimento do nível de imobilização em proporção à receita das empresas do Grupo B, que provavelmente incorreram em maior nível de CDF relacionados à depreciação.

Já para as empresas do grupo C, o saldo de imobilizado sobre receitas líquidas foi de 0,52 (a metade das vendas líquidas) e cresceu $2,45 \%$ no período, demonstrando que a proporção de ativo imobilizado em relação à REC nas empresas desse grupo, vêm aumentando, consequentemente, é possível que as empresas do Grupo C, proporcionalmente, incorreram em maiores $\mathrm{CDF}$ relativos à depreciação comparativamente à receita.

Os indicadores $\mathrm{MO}$ e RO demonstram uma diferença clara de desempenho entre os grupos. As empresas com desempenho acima da média (Grupo A) são as empresas com maior REC média e estas reduziram a proporção de estoque sobre receitas e aumentaram a proporção de imobilizado sobre a receita. $\mathrm{O}$ crescimento médio da proporção de Ativos Imobilizados pode estar relacionado à expansão da capacidade instalada, reflexo do bom momento vivido pelo setor no Brasil.

Segundo dados do Instituto do Aço para o primeiro bimestre de 2011, em relação ao mesmo periodo de 2010, as vendas no mercado interno cresceram 9,3\% e para o mercado externo $46,8 \%$, sendo que, no mercado interno, a produção é prioritariamente de produtos acabados (laminados - planos e longos), principalmente para a indústria de construção civil, autopeças e bens de consumo. Já para o mercado externo, a maior parte das vendas é de produtos semiacabados (placas e blocos). Tal crescimento em 2011 justifica o aumento dos níveis de estoques e imobilização, observados nas empresas do setor Siderurgia/Metalurgia no período de 2005 a 2009.

Uma vez analisados os indicadores contábeis das empresas do setor Siderurgia/Metalurgia, analisou-se a relação entre os CDF com MO e RO para as empresas que apresentaram desempenho positivo (grupos A e B). Os dados podem ser observados nos Gráficos 6 e 7. 


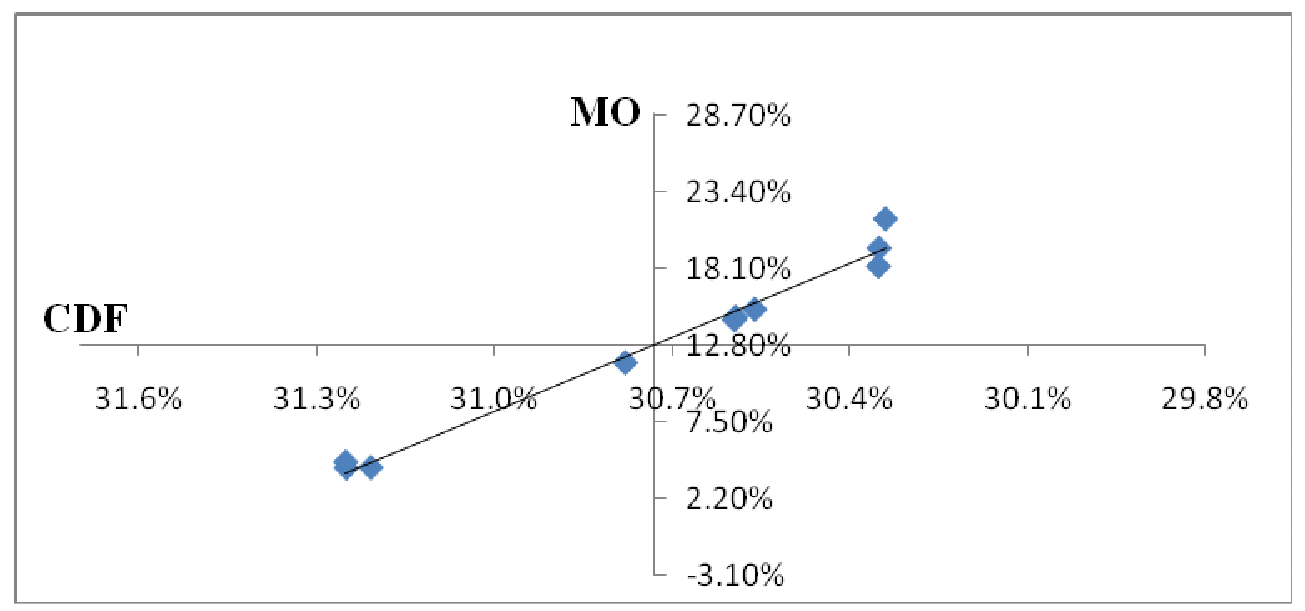

Gráfico 6 - Relação entre CDF e MO no setor Siderurgia/Metalurgia

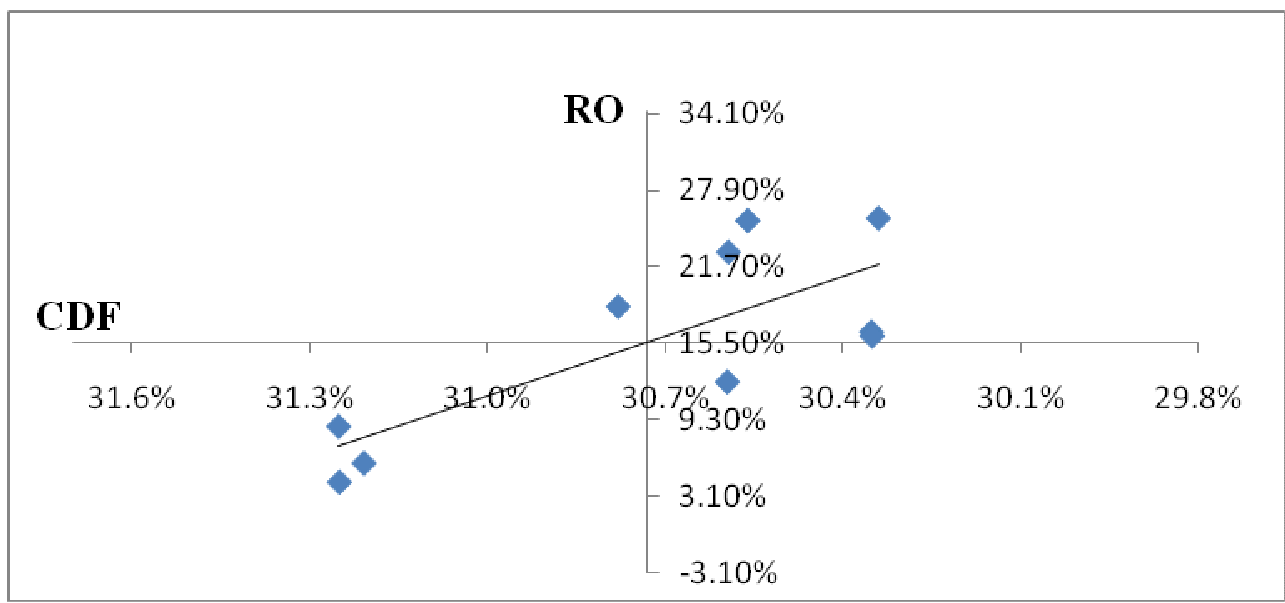

Gráfico 7 - Relação entre CDF e RO no setor de Siderurgia/Metalurgia

Os gráficos demonstram que existe uma forte correlação negativa entre os indicadores de desempenho MO e RO e a proporção de CDF. Em geral, as empresas com menor participação de custos e despesas fixas tiveram o desempenho acima da média (primeiro quadrante) e as empresas com CDF acima da média tiveram desempenho abaixo da média (terceiro quadrante). O Quadro 10 demonstra que a correlação é maior entre CDF e MO.

Quadro 10 - Correlação entre CDF e MO/RO na Siderurgia/Metalurgia (Grupos A e B)

\begin{tabular}{|l|c|}
\hline Correl (CDF; MO) & $-99,06 \%$ \\
\hline Correl (CDF; RO) & $-78,49 \%$ \\
\hline
\end{tabular}

Após identificar que existe uma relação entre estrutura de custo e despesa com os indicadores de desempenho das empresas, o desafio foi encontrar quais os limites de CDF das empresas que tiveram MO e RO negativo, acima e abaixo da média no período. Inicialmente, construiu- 
se a tabela dos valores estimados de CDF relacionando com indicadores de desempenho acima e abaixo da média da amostra.

Quadro 11 - Relação de CDF com MO/RO na Siderurgia/Metalurgia

\begin{tabular}{|c|c|c|c|c|c|c|}
\hline & $\begin{array}{c}\text { c/ MO } \\
\text { acima }\end{array}$ & $\begin{array}{c}\text { c/ MO } \\
\text { abaixo }\end{array}$ & $\begin{array}{c}\text { c/ MO } \\
\text { negativo }\end{array}$ & $\begin{array}{c}\text { c/ RO } \\
\text { acima }\end{array}$ & $\begin{array}{c}\text { c/ RO } \\
\text { abaixo }\end{array}$ & $\begin{array}{c}\text { c/ RO } \\
\text { negativo }\end{array}$ \\
\hline Mínimo & $30,34 \%$ & $30,78 \%$ & $31,79 \%$ & $30,34 \%$ & $30,60 \%$ & $31,79 \%$ \\
\hline Máximo & $30,60 \%$ & $31,25 \%$ & $32,16 \%$ & $30,78 \%$ & $31,25 \%$ & $32,16 \%$ \\
\hline
\end{tabular}

Em seguida, construíram-se os intervalos de CDF dessas empresas relacionando com os indicadores MO e RO negativos, acima e abaixo da média para descobrir qual foi a região dos CDF das empresas que apresentaram desempenho negativo, acima e abaixo da média.

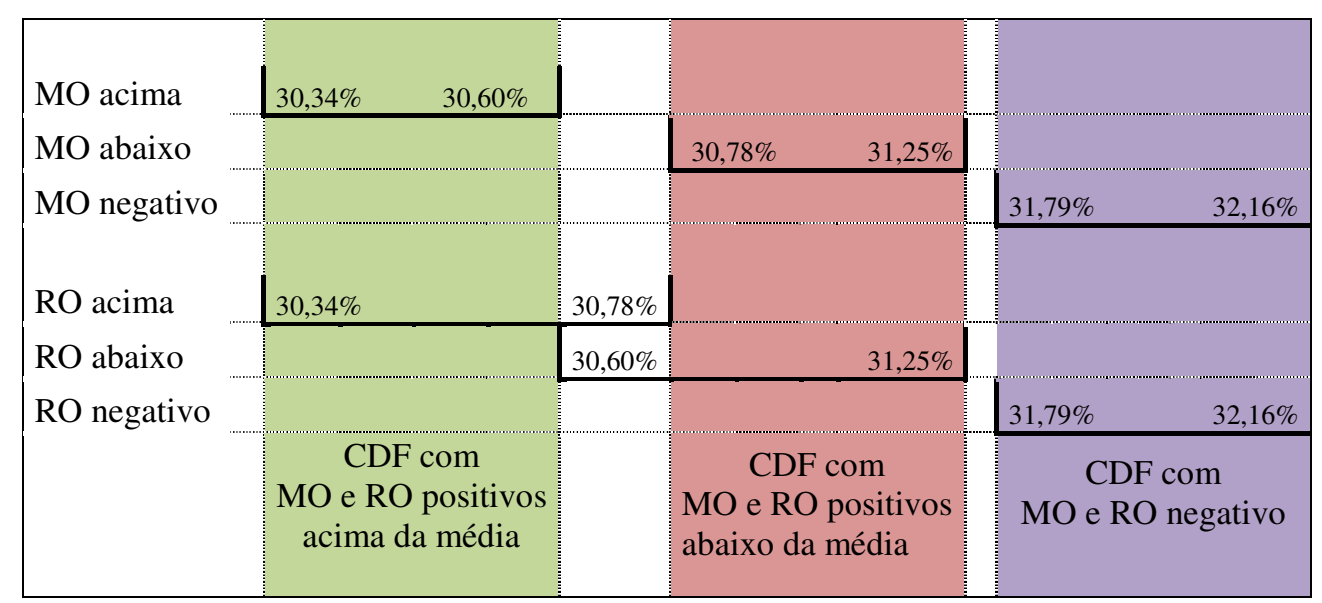

Ilustração 4 - Intervalo de CDF com MO/RO: Siderurgia/Metalurgia

Conforme pode ser observado na Ilustração 4, as empresas que obtiveram MO e RO positivos e acima da média foram aquelas que mantiveram a proporção de custo e despesa fixa entre $30,34 \%$ e $30,60 \%$ de CDT, enquanto que as empresas que mantiveram uma proporção de CDF entre 30,78\% e 31,25\% tiveram os indicadores positivo, porém abaixo da média. Já as empresas do setor Siderurgia/Metalurgia com CDF entre 31,79\% e 32,16\% tiveram indicadores de desempenho negativo no período.

De uma forma geral, a análise dos indicadores contábeis das empresas do setor Siderurgia/Metalurgia demonstrou que as empresas com maior MO e RO são empresas de maior porte (em termos de receita líquida) e que estas promoveram redução no saldo médio de estoques e aumento do saldo médio de Ativo imobilizado no período de 2005 e 2009, reflexo do bom momento que vive o setor, tanto no mercado interno quanto externo. 
A análise da estrutura de custo e despesa das empresas do setor de Siderurgia/Metalurgia fornece um panorama para os gestores dessas empresas que, embora não possa ser apontado como o fator determinante do desempenho, é uma informação que pode ser útil para conhecimento do mercado e de seus concorrentes e para o alinhamento da estratégia de gestão de custos.

\subsection{Comparação entre os dois setores pesquisados}

Este item é dedicado a analisar e discutir as diferenças que puderam ser observadas entre os dois setores, iniciando-se com a comparação dos indicadores contábeis para os dois grupos de empresas com desempenho positivo no período.

Conforme analisado, ambos os setores pesquisados apresentaram grupos bem definidos contendo empresas com indicadores de desempenho (MO e RO) positivos e negativos e, dentre as empresas em que esses indicadores foram positivos no período, também houve uma clara divisão entre um grupo de empresas com desempenho acima e outro abaixo da média.

Também pôde ser percebido, a partir das análises, uma forte correlação negativa entre a estrutura de custo e despesa com a $\mathrm{MO}$ e a RO, tanto para as empresas do setor Têxtil, quanto de Siderurgia/Metalurgia, e ainda foi identificada uma região onde a proporção de CDF estava relacionada aos indicadores de $\mathrm{MO}$ e RO negativo, acima e abaixo da média.

Dessa forma, constatou-se que os patamares da estrutura de custo e despesa dos setores são diferentes devido às características particulares de cada setor. O Têxtil possui menor proporção de CDF do que o de Siderurgia/Metalurgia; porém, em ambos os setores analisados, as empresas que tiveram desempenho superior foram também as que tiveram um nível de CDF proporcionalmente menor.

Analisando-se o grupo de empresas com desempenho acima da média (Grupo A), as empresas dos dois setores tiveram crescimento médio das receitas próximos ou acima de $10 \%$ ao ano, no período estudado. Ambos os setores foram beneficiados pelo aquecimento da economia 
brasileira no período, especialmente o setor Têxtil, pois houve um crescimento maior, já que está voltado majoritariamente para o mercado interno.

Quadro 12 - Comparação de indicadores entre setores para empresas do Grupo A

\begin{tabular}{|l|r|r|r|r|}
\hline \multirow{2}{*}{ Indicador } & \multicolumn{2}{c|}{ Têxtil } & \multicolumn{2}{c|}{ Siderurgia/Metalurgia } \\
\hline REC (em R\$ milhões) & \multicolumn{1}{c|}{ Média } & \multicolumn{1}{c|}{$\begin{array}{c}\text { Cresc. } \\
\text { Médio }\end{array}$} & \multicolumn{1}{c|}{ Média } & \multicolumn{1}{c|}{$\begin{array}{c}\text { Cresc. } \\
\text { Médio }\end{array}$} \\
\hline CDT / REC & 756,88 & $16,31 \%$ & 549,55 & $9,36 \%$ \\
\hline Estoque / REC & 0,87 & $1,62 \%$ & 0,83 & $0,18 \%$ \\
\hline Imobilizado / REC & 0,13 & $5,84 \%$ & 0,23 & $-0,92 \%$ \\
\hline MO & 0,35 & $-7,02 \%$ & 0,26 & $8,96 \%$ \\
\hline RO & $13,42 \%$ & & $17,29 \%$ & \\
\hline CDF & $12,99 \%$ & & $19,77 \%$ & \\
\hline CDV & $20,51 \%$ & & $30,47 \%$ & \\
\hline
\end{tabular}

Quanto ao indicador CDT/REC percebe-se que, no setor Siderurgia/Metalurgia, os CDT representam $83 \%$ das REC enquanto que, no setor Têxtil, esse indicador é de 87\%, justificando o fato de o desempenho observado (MO e RO) ser maior nas empresas de Siderurgia/Metalurgia.

A média do indicador CDT/REC das empresas do Grupo A nos dois setores ficou em torno de 0,8, no entanto, o crescimento desse indicador no setor Têxtil $(1,62 \%)$ foi superior ao crescimento do indicador nas empresas do setor Siderurgia e Metalurgia $(0,18 \%)$, indicando que as proporção de custos e despesas sobre as receitas é maior no setor Têxtil.

Já para o indicador Estoque/REC percebe-se que a Siderurgia/Metalurgia trabalhou com um nível de estoque proporcional às receitas líquidas maior, o que pode ser reflexo do aquecimento no setor de construção civil e de autopeças no período, principais consumidores de aço produzido por essas empresas no mercado interno. O menor nível de estoque para o setor Têxtil pode ser atribuído às características e peculiaridades de seu segmento (sazonalidade, moda etc.) que são totalmente divergentes dos produtos gerados pelas empresas da indústria do aço.

$\mathrm{O}$ indicador Imobilizado/REC cresceu 8,96\% nas empresas do Grupo A do setor Siderurgia/Metalurgia enquanto que nas empresas do setor Têxtil esse indicador teve retração de $-7,02 \%$. Mauer e Ott (1995) explicam que, quando o ambiente possui maior grau de 
incerteza, os gestores tendem a retardar as decisões de investimento; no caso desta análise, o setor com menor crescimento de investimento (em ativos imobilizados) proporcional a receita foi o Têxtil, levando a crer que a percepção de incerteza dos gestores das empresas do setor Siderurgia/Metalurgia é menor.

As empresas do Grupo A do setor Têxtil tiveram em média a proporção de 20,5\% de CDF no período, sendo que se percebe que, para essas empresas, houve redução do nível de Ativo Imobilizado e aumento no nível de Estoque. Por outro lado, as empresas Grupo A da Siderurgia/Metalurgia tiveram em média uma proporção de 30,5\% de CDF, e o comportamento dos indicadores foi o inverso das empresas do Têxtil, houve redução do nível de estoque e aumento do nível de ativos imobilizados.

A seguir analisam-se comparativamente as características dos indicadores e estrutura de custo e despesa das empresas Grupo B dos dois setores.

Quadro 13 - Comparação de indicadores entre setores para empresas do Grupo B

\begin{tabular}{|l|r|r|r|r|}
\hline \multirow{2}{*}{ Indicador } & \multicolumn{2}{|c|}{ Têxtil } & \multicolumn{2}{c|}{ Siderurgia/Metalurgia } \\
\hline & \multicolumn{1}{|c|}{ Média } & \multicolumn{1}{c|}{$\begin{array}{c}\text { Cresc. } \\
\text { Médio }\end{array}$} & \multicolumn{1}{c|}{ Média } & \multicolumn{1}{c|}{$\begin{array}{c}\text { Cresc. } \\
\text { Médio }\end{array}$} \\
\hline REC (em R\$ milhões) & 231,65 & $6,18 \%$ & 125,87 & $5,80 \%$ \\
\hline CDT / REC & 0,95 & $1,22 \%$ & 0,94 & $0,55 \%$ \\
\hline Estoque / REC & 0,21 & $-1,37 \%$ & 0,14 & $2,75 \%$ \\
\hline Imobilizado / REC & 0,38 & $1,45 \%$ & 0,32 & $15,77 \%$ \\
\hline MO & $4,84 \%$ & & $6,21 \%$ & \\
\hline RO & $4,68 \%$ & & $9,30 \%$ & \\
\hline CDF & $21,06 \%$ & & $31,12 \%$ & \\
\hline CDV & $78,94 \%$ & & $68,88 \%$ & \\
\hline
\end{tabular}

Assim como no Grupo A, a receita média das empresas do Grupo B é maior no setor Têxtil. Percebe-se também que o crescimento médio das receitas das empresas do Grupo B, em ambos os setores, foi inferior ao das empresas do Grupo A. Nas empresas do Têxtil houve crescimento da receita líquida de $8,2 \%$ em cinco anos, enquanto que, nas da Siderurgia/Metalurgia, as REC cresceram somente 7,3\% no mesmo período.

Nas empresas do setor Têxtil do Grupo B, os CDT cresceram mais do que as receitas enquanto que, no setor Siderurgia/Metalurgia, foi o contrário. Proporcionalmente, as empresas 
do setor Siderurgia/Metalurgia do Grupo B são mais lucrativas, pois possuem um indicador CDT/REC levemente menor.

O nível de estoque das empresas do setor Têxtil representou $20 \%$ das receitas líquidas, enquanto que, no setor Siderurgia/Metalurgia, esse indicador é de 14\%. Nesse sentido, parece que a importância relativa do estoque é maior para o setor Têxtil do que o setor Siderurgia/Metalurgia. Assim, considerando que a receita média das empresas do grupo B do setor Têxtil foi maior, possivelmente, as empresas desse grupo e setor (Têxtil) incorreram em maiores CDF relacionados à armazenagem.

O nível de ativos imobilizados das empresas do setor Têxtil também é proporcionalmente maior: representa $38 \%$ da receita líquida, enquanto que, nas empresas do setor Siderurgia/Metalurgia, esse indicador é de 32\%. Entretanto, no período estudado, observou-se que os saldos médios tanto de estoques quanto de ativo imobilizado das empresas do setor Siderurgia/Metalurgia cresceram mais do que as do Têxtil.

Quanto às divergências na estrutura de custo e despesa das empresas Grupo B dos setores analisados, percebeu-se que o setor Têxtil tem menor participação de CDF $(21,06 \%)$ na estrutura de custo e despesa total do que as empresas do setor Siderurgia/Metalurgia $(31,12 \%)$.

Considerando as estruturas de custo e despesa dos Grupos A e B, percebeu-se que, além das diferenças entre o nível de CDF entre setores, internamente também há um intervalo de CDF que caracteriza as empresas que tiveram indicadores de desempenho acima da média. Constatou-se que há forte correlação negativa entre a proporção de CDF e os indicadores MO e RO.

Constatou-se também que o intervalo de CDF das empresas do setor Têxtil que tiveram um desempenho acima da média foi maior, entre $20,15 \%$ e $20,76 \%$, enquanto que, para o setor de Siderurgia/Metalurgia, as empresas com desempenho acima da média possuíam o intervalo de CDF entre 30,34\% e 30,60\%, conforme demonstra o Quadro 14. 
Quadro 14 - Intervalo de CDF das empresas com MO e RO acima da média

\begin{tabular}{|c|c|c|}
\hline CDF & Setor Têxtil & Setor Sider. Metal. \\
\hline Min & $20,15 \%$ & $30,34 \%$ \\
\hline Max & $20,76 \%$ & $30,60 \%$ \\
\hline Intervalo & 0,61 & 0,26 \\
\hline
\end{tabular}

Percebe-se que as empresas do setor Siderurgia/Metalurgia possuem um patamar de CDF maior do que as do setor Têxtil. Além disso, o intervalor entre o máximo e o mínimo do Setor Têxtil é maior do que o do Setor de Siderurgia/Metalurgia, indicando que no segundo existe uma menor margem de gerenciamento.

Dessa forma, comprova-se que cada setor da economia deve trabalhar com um nível de CDF de acordo com as suas características estruturais; no entanto, dentro dos setores existe um intervalo comum da estrutura de custos e despesas às empresas que tiveram desempenho (MO e RO) negativo, acima e abaixo da média.

Se por um lado os gestores das empresas do setor Siderurgia/Metalurgia têm menos flexibilidade para alterar estrutura de custo e despesa, por outro lado, por operarem com maior participação de CDF, possuem maior margem de gestão do lucro, pois, segundo Cook et al (2007), quanto maior a participação de CDF na estrutura de custos, maior a margem para gestão dos lucros com a gestão do nível de produção.

As empresas do setor Siderurgia/Metalurgia possuem, em média, uma estrutura de custo e despesa com maior proporção de CDF do que as do setor Têxtil; consequentemente, sua margem de contribuição, que é a diferença entre receitas líquidas e CDV, é relativamente maior. Dessa forma, as empresas do setor Siderurgia/Metalurgia lucram mais do que as do setor Têxtil após alcançarem o ponto de equilíbrio contábil (PEC). Por outro lado, quando as empresas de Siderurgia/Metalurgia trabalham abaixo do ponto de equilíbrio contábil, seus prejuízos são maiores.

Guerra et al (2007, p. 237) realizaram estudo comparando estrutura de custos de empresas do setor de Serviços e Manufatura e concluíram que, em empresas com maior proporção de CDF, o impacto das receitas sobre os lucros é maior. As inferências dos autores sobre essa informação das empresas foi realizada por meio da análise do GAO e da lucratividade. Constatou-se que as empresas do setor Serviços tiveram maior proporção de CDF. 
Nesta tese, foram estimadas as funções custo dos dois setores e constatou-se que o coeficiente angular da variável REC, que foi utilizada como proxy do volume de produção, é maior no setor Têxtil $(78,6 \%)$ do que no Siderurgia/Metalurgia $(68,5 \%)$. Isso significa que o primeiro setor é mais influenciado pelo volume de atividades.

Constatou-se também que o setor Têxtil tem menor proporção de CDF. Assim, corroborando com os achados de Guerra et al (2007), para as empresas do setor Têxtil (com menor proporção de CDF) o impacto da variação das receitas líquidas sobre o lucro é menor.

Como pode ser observado nesta tese, foram identificadas muitas diferenças na estrutura de custo e indicadores dos dois setores estudados e, principalmente, foi descoberto que em cada setor existe uma faixa de estrutura de custos e despesas específica que pode ter permitido que algumas empresas tivessem melhor desempenho que outras. Espera-se que a metodologia utilizada, bem como as análises realizadas, possam estimular os acadêmicos a testarem cada vez mais essa e outras ferramentas de estimação para preencher a lacuna encontrada na literatura sobre o tema, observada por Guilding (1999, p. 584).

Cabe aos pesquisadores da área de Controladoria e Contabilidade Gerencial se aprofundar na questão, para identificar o que pode estar afetando a eficiência, a qualidade e a competitividade da estrutura de custos e despesas de cada setor, analisando como os determinantes de custos - tecnologia, escala, nível de utilização de capacidade, complexidade, curva de experiência, entre outros - impactam na estrutura de custos e despesas, alcançando novos conhecimentos. Além disso, os pesquisadores poderão replicar a técnica em outros setores ou períodos, e poderão fazer comparações com este estudo.

Cabe aos profissionais de mercado, principalmente os responsáveis por decisões estratégicas nas empresas, analisar a situação atual da empresa e comparar com o desempenho descrito no painel fornecido por esta tese para influenciar na estratégia que a empresa está tomando e tentar melhorar o desempenho da rentabilidade e lucratividade operacional, com o objetivo de maximizar o valor da empresa. A tese ajuda a demonstrar que as organizações podem dispor de um mecanismo que lhes permita monitorar e detectar "hipertensão estrutural de custos e despesas", evitando que os gestores se acomodem com níveis elevados de utilização de recursos fixos que podem comprometer, silenciosamente, a rentabilidade e a lucratividade da 
empresa. Já para os profissionais que atuam nas áreas de Gestão de Custos e Inteligência Competitiva, espera-se que esta tese lhes seja útil para aprimorar seu sistema de monitoramento do mercado, tanto competidores quando parceiros, seja para tomar decisões estratégicas, seja para utilizar informações como benchmarking. 


\section{CONSIDERAÇÕES FINAIS}

A composição da estrutura de custos e despesas pode influenciar na estratégia competitiva das organizações, porém, o oposto também pode ser verdadeiro. Dessa forma, é importante conhecer a própria estrutura de custo e despesa, como, também, a dos seus principais competidores. Decisões importantes podem ser tomadas a partir do conhecimento dessas informações, como, por exemplo: a forma como deteminados serviços serão contratados, a movimentação interna de insumos, a gestão de produtos, processos e pessoas, a gestão de preços, terceirização de atividades etc.

A estrutura de custos e despesas das empresas influencia também na sensibilidade dos lucros em relação às variações das receitas, sendo que, em empresas com maior proporção de CDF, os lucros são mais sensíveis às variações na receita. Os custos e despesas fixas existem em função do montante e da complexidade das atividades que a empresa mantêm.

Apesar disso, há uma carência na literatura contábil, principalmente em relação a pesquisas empíricas, de tentativas de sínteses de práticas de estimação, análise e discussão da estrutura de custo de empresas e de seus concorrentes. Organizações podem ter dificuldades de acesso a tais informações, mesmo quando possuem departamentos, ou equipes funcionais, que sejam responsáveis por essa atividade.

Conforme foi destacado, muitos profissionais que atuam com inteligência competitiva não conseguem sequer saber qual a estrutura de custos e despesas da própria empresa. Além disso, outros não consideram factível estimar os custos dos concorrentes por acreditar que existe um alto grau de complexidade nessa tarefa.

Pesquisas anteriores, discutidas no texto, sobre investigação de estrutura de custos, utilizaram regressão simples ou análise do GAO para abordar a estrutura de custos de empresas. Esses trabalhos, entretanto, ou apresentaram problemas com os parâmetros da regressão, ou não tiveram como objetivo estimar a proporção de CDF e CDV.

Outros trabalhos buscaram contribuir para a pesquisa nesse campo com uma abordagem mais qualitativa, contribuindo para organizar o arcabouço teórico sobre o tema. 
A investigação desenvolvida nesta tese, buscou relacionar a estrutura de custos e despesas com a lucratividade e a rentabilidade das empresas, e é um instrumento de apoio aos gestores no processo de tomada de decisão. Apoiou-se na Teoria da Maximização da Riqueza dos Acionistas, que prega que os gestores devem ser orientados a tomar suas decisões no sentido de maximizar o valor total da empresa.

\section{$5.1 \quad$ Limitações da pesquisa}

A primeira limitação deste estudo ocorre devido aos resultados estarem apoiados na utilização de uma modelagem econométrica, que está sujeita a restrições, pois, todo modelo representa uma simplificação da realidade; porém, para minimizar essa limitação, todos os pressupostos foram testados e não apresentaram problemas significativos.

Outra limitação do estudo refere-se à heterogeneidade das empresas no que diz respeito às atividades principais que desenvolvem. Entretanto, o modelo de regressão com dados em painel de efeitos fixos pode controlar essas diferenças no intercepto.

Cabe ressaltar que este estudo pode e deve ser melhorado a partir de confirmações empíricas, possivelmente com entrevistas junto aos gestores das empresas pesquisadas, para que possam corroborar os resultados encontrados. Esse é o próximo passo da continuidade de um projeto de pesquisa, obtendo e discutindo os dados reais de algumas empresas pesquisadas para ajudar a validar os achados. Adicionalmente, pretende-se analisar a viabilidade de construção de uma tabela dos principais setores econômicos do Brasil, ampliando a base de pesquisa desta tese, e que, se possível, seja atualizada anualmente.

\subsection{Considerações gerais}

Considera-se respondida a questão de pesquisa proposta nesta tese: "qual foi a composição da estrutura de custos e despesas das empresas que tiveram desempenho econômico acima da média, no período de 2005 a 2009, de dois setores da economia brasileira." Conforme a Ilustração 5, para o setor Têxtil, o intervalo da composição da estrutura de custos e despesas 
ficou entre 20,15\% e 20,76\% de CDF e, consequentemente, 79,85\% e 79,24\% de CDV. Já para o setor Siderurgia/ Metalurgia o intervalo ficou entre 30,34\% e 30,60\% de CDF e, consequentemente, $69,66 \%$ e $69,40 \%$ de CDV.

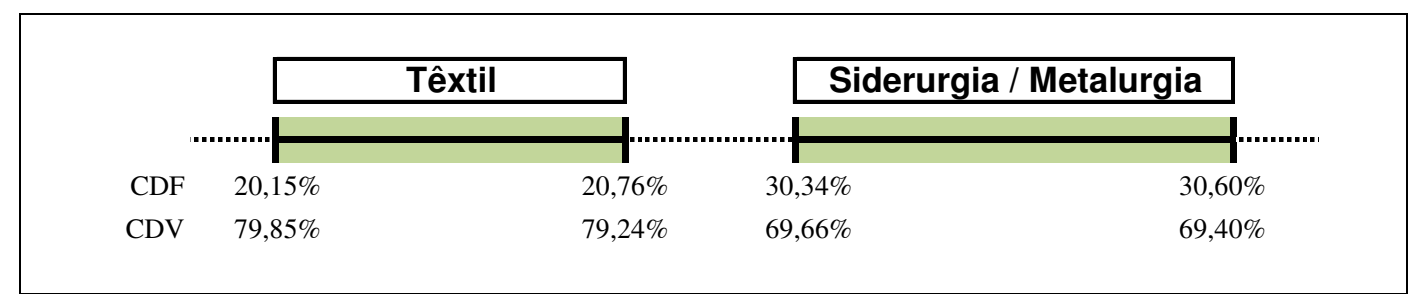

Ilustração 5 - Intervalo da composição da estrutura de custos e despesas das empresas com MO e RO positivos e acima da média

O primeiro objetivo desta tese foi realizar a estimação da composição da estrutura de custos e despesas, a partir de um modelo econométrico (regressão com dados em painel). Foram estimadas as funções de custos e despesas de empresas de dois setores (Têxtil e Siderurgia/Metalurgia) no período de 2005-2009. Além disso, também se calculou a proporção média de custos e despesas fixas e variáveis dessas entidades no mesmo período.

O segundo objetivo foi investigar a relação de dois indicadores de desempenho - Margem Operacional (MO) e Rentabilidade Operacional (RO) - com a estrutura de custos e despesas das empresas, nos dois setores, a fim de analisar e discutir se há um comportamento padrão observado nesses parâmetros. O terceiro objetivo, foi indentificar um intervalo em que a proporção de CDF e CDV está relacionado com níveis de desempenho diferenciados em cada setor.

Respondendo o segundo e o terceiro objetivos, verificou-se que existe uma correlação inversamente proporcional entre CDF com MO e RO. Construiu-se também o intervalo da estrutura de custos e despesas em que as empresas com indicadores de desempenho negativos, acima e abaixo da média, operaram durante o período estudado (conforme Ilustrações 3 e 4 demonstradas no capítulo 4). 


\subsection{Considerações específicas}

Estimou-se a função custos e despesas médias, de duas amostras de empresas, uma do setor Têxtil e outra do Siderurgia/Metalurgia. Utilizou-se a técnica de regressão com dados em painel para estimar essas funções, em que a variável dependente foi custos e despesas totais (CDT) e as variáveis explicativas foram: receita líquida (REC) e ativo imobilizado (IMOB). $\mathrm{Na}$ função custos e despesas do setor Têxtil, no entanto, o IMOB não foi significativo para explicar os CDT, sendo utilizado apenas a REC como variável explicativa.

Analisando-se o comportamento da estrutura de custos e despesas dos dois setores e o cenário econômico no período de 2005 a 2009, constatou-se que ambos tiveram retração de CDF em 2008, ano de maior incerteza nos mercados devido à crise financeira iniciada no segundo semestre de 2007. Essa constatação é uma confirmação empírica de que as empresas reduzem investimentos que geram $\mathrm{CDF}$ em períodos de maior incerteza.

Verificou-se também que o setor Têxtil possui, em média, menor proporção de CDF em sua estrutura de custos e despesas $(21,48 \%)$ do que o Siderurgia/Metalurgia $(31,07 \%)$. Além disso, internamente, cada setor possui grupos de empresas com estrutura de custo e despesa distintos.

Esses grupos, por sua vez, possuem indicadores de desempenho MO e RO diferenciados, sendo que, quanto menor o nível de CDF dentro de cada setor, maiores os indicadores de desempenho.

Estimou-se o intervalo de estrutura de custos e despesas das empresas que tiveram indicadores de desempenho negativo (Grupo C), positivos e acima da média (Grupo A), e positivos mas abaixo da média (Grupo B).

Constatou-se que, no setor Têxtil, as empresas do Grupo A possuem uma proporção de custos e despesas fixas (CDF) entre 20,15\% e 20,76\%. Enquanto que as empresas do Grupo C tiveram CDF entre $21,70 \%$ e $24,00 \%$, no período analisado. Esses resultados sugerem que a estrutura de custos e despesas alvo, para as empresas desse setor, seja a do Grupo A. 
Já para as empresas do setor de Siderurgia/Metalurgia, as empresas do Grupo A tiveram o intervalo de proporção de CDF de 30,34\% a 30,60\%, Por outro lado, nas empresas do Grupo C, esse intervalo foi de $31,79 \%$ a $32,16 \%$.

Percebe-se que as empresas do setor Siderurgia/Metalurgia possuem níveis maiores custos e despesas fixas do que as do Têxtil, porém, a diferença entre o máximo e mínimo de CDF no Grupos A desse setor é de 0,26\%, (30,60\% - 30,34\%), enquanto que no setor Têxtil essa diferença é de $0,61 \%(20,76 \%$ - 20,15\%). Esse resultado sugere que setor Siderurgia/Metalurgia tem uma menor margem de gerenciamento.

Constatou-se também que a lucratividade e o retorno não estão relacionados apenas ao porte das organizações. Considerando o valor médio das receitas líquidas (REC) como proxy do porte das empresas, em ambos os setores, as que pertencem ao Grupo A são maiores. No entanto, dentre as empresas desse Grupo (nos dois setores), existem algumas que possuem REC menor do que as empresas dos outros dois grupos (Grupos B e C). Dessa forma, concluíse que a lucratividade e retorno das organizações estão mais relacionados com sua estrutura de custos e despesas do que com o seu porte.

De acordo com Teoria do Crescimento da Firma, o crescimento organizacional não é uma finalidade, mas apenas uma parte do processo que gera valor nas entidades e, do ponto de vista econômico, a motivação para esse crescimento é a geração de dinheiro; assim, os lucros seriam desejados para o próprio proveito da firma e para gerar ainda mais lucros. $\mathrm{O}$ crescimento, portanto, pode significar destruição do valor da firma, quando provocar mudanças desfavoráveis na sua estrutura de custos e despesas. Os gestores das empresas devem adequar a estratégia de crescimento das organizações, considerando seu impacto na estrutura de custos e despesas, a fim de alinhar este crescimento ao objetivo principal da firma, ou seja, a maximização seu próprio valor.

É importante lembrar que esta pesquisa contribui para a academia e para as organizações fornecendo um caminho metodológico para prover subsídios a fim de conhecer a estrutura de custos e despesas de um grupo de empresas durante determinado período de análise.

O cenário encontrado nesta pesquisa pode incentivar decisões tanto na prática empresarial quanto na pesquisa acadêmica. Na prática, a tese apresenta uma metodologia para se estimar a 
estrutura de custo e despesa de empresas com utilização de dados públicos, o que pode ser utilizado pelas empresas, com base no conhecimento de sua própria estrutura, como base de comparação de seu setor econômico e, também, de outros setores, podendo avaliar aspectos de rentabilidade, lucratividade e risco.

Por outro lado, cabe aos pesquisadores se aprofundarem na questão, para identificar o que pode estar afetando a eficiência, a qualidade e a competitividade da estrutura de custos de cada setor, analisando como os determinantes de custos - tecnologias, escalas, nível de utilização de capacidade, complexidade, curva de experiência, entre outros - impactam na estrutura de custos e despesas, alcançando novos conhecimentos. 


\section{REFERÊNCIAS}

ABDI - Agência Brasileira de Desenvolvimento Industrial. Estudo prospectivo setorial: Setor têxtil e confecções. Série Cadernos da Indústria ABID, volume XVIII. Brasília, 2010.

ALTMAN, Edward I. Financial ratios, discriminant analysis and the prediction of corporation bankruptcy. Journal of Finance, Pennsylvania, v. 23, n. 4, p. 589-609, 1968.

ANDERSON, Shannon W. Managing costs and cost structure throughout the value chain: Research on strategic cost management. Handbook of Management Accounting Research, Oxford, v. 2, 2006.

ANTHONY, Robert N.; GOVINDARAJAN, Vijay. Sistemas de controle gerencial. 12. ed. São Paulo: McGraw-Hill, 2008.

ARISOY, Ozlem; GOKHAN, N. Mehmet; NEEDY, Kim LaScola; BIDANDA, Bopaya. Activity based costing and life cycle costing in outsourcing decision analysis department of industrial engineering. USA: University of Pittsburgh. Pittsburgh, PA 15261, 2006.

ASSAF NETO, Alexandre. Estrutura e análise de balanços: um enfoque econômicofinanceiro. São Paulo: Atlas, 2008.

BACEN - Banco Central do Brasil. Boletim do Banco Central do Brasil: Relatório anual 2005. Disponível em: <http://www.bacen.org.br>. Acesso em: 15/04/2011.

Boletim do Banco Central do Brasil: Relatório anual 2006. Disponível em: $<$ http://www.bacen.org.br>. Acesso em: 15/04/2011.

Boletim do Banco Central do Brasil: Relatório anual 2007. Disponível em: $<$ http://www.bacen.org.br>. Acesso em: 15/04/2011.

- Boletim do Banco Central do Brasil: Relatório anual 2008. Disponível em: $<\mathrm{http}$ ://www.bacen.org.br>. Acesso em: 15/04/2011.

Boletim do Banco Central do Brasil: Relatório anual 2009. Disponível em: $<\mathrm{http}$ ://www.bacen.org.br>. Acesso em: 15/04/2011.

BALDUÍNO, João Herivelto. Estudo de caso de informações sobre competidores em uma empresa industrial. São Paulo. 2003. Dissertação (Mestrado em Contabilidade) - Faculdade de Economia, Administração e Contabilidade, Universidade de São Paulo. 
BANKER, Rajiv D., CHARNES, Abraham., COOPER, William. W. Some models for estimating technical and scale inefficiencies in data envelopment analysis. Management Science, [S.1.], v. 30, n. 9, p. 1078-1092, 1984.

BEAVER, William H. Financial ratios as predictors of failure. Empirical Research in Accounting: Selected Studies. Supplement of Journal of Accounting Research, Chicago, p.71-111, 1966.

BLOCHER, Edward J.; CHEN, Kung H.; LIN, Thomas W. Cost management. 2nd ed. New York: McGraw-Hill, 2002.

BLOCHER, Edward; STOUT, David E.; COKINS, Gary. Cost management: a strategic emphasis. 5th ed. New York: McGraw-Hill, 2010.

BORINELLI, Márcio Luiz. Estrutura conceitual básica de controladoria: sistematização à luz da teoria e da práxis. São Paulo. 2006. Tese (Doutorado em Contabilidade) - Faculdade de Economia, Administração e Contabilidade, Universidade de São Paulo.

BOSCOV, Camila Pereira; ROCHA, Welington. Sistemas de informação sobre concorrentes: uma análise sobre a teoria e a praxis sobre o papel da controladoria. In: CONGRESSO USP DE INICIAÇÃO CIENTÍFICA EM CONTABILIDADE. São Paulo, 1, 2004.

BREALEY, Richard A.; MYERS, Stewart C.; GOMES, Marcus Alan de Melo. Fundamentos da administração financeira. 3. ed. São Paulo: McGraw-Hill, 2003.

BREWER, Peter C. et al. Economica value added (EVA): its uses and limitations. Advanced Management Journal, [S.1.], v. 6, n. 2, 1999.

BRICIU, Sorin; SAS, Florentina. The crisis an cost management. Annales Universitatis Apulensis Series Oeconomica, [S.1.], v. 11, 2009.

BRIMSON, James A. Contabilidade por atividades. São Paulo: Atlas, 1996.

BRITO, Giovani Antonio Silva; ASSAF NETO, Alexandre. Modelo de Classificação de Risco de Crédito de Empresas. Revista Contabilidade \& Finanças, São Paulo, v. 46, p. 1829, 2008.

BURDISSO, Tamara. Estimación de una función de costos para los bancos privados argentinos utilizando datos en panel. Documento de Trabajo, Buenos Aires, Banco Central de la Republica de Argentina, n. 3, 1997.

CASELlA, Bruna Maria Barbosa Xavier. Análise de custos de concorrentes. Análise exploratória do setor de celulose e papel. São Paulo. 2008. Dissertação (Mestrado em 
Contabilidade) - Faculdade de Economia, Administração e Contabilidade, Universidade de São Paulo.

CHARNES, A., COOPER, W.W., RHODES, E. Mensuring the eficiency of decision making units. European Journal of Operation Research, [S.1.], v. 2, p. 429-444, 1978.

CHUCK, Anderson; JOCOBS, Philip; LOGUS, J. Wayne; HILAIRE, Donald St.; CHMIELOWIEC, Chester; MCEWAN, Alexander J. B. Marginal cost of operating a positron emission tomography center in a regulatory environment international. Journal of Technology Assessment in Health Care, Cambridge, v. 21, n. 4, p. 442-451, 2005.

COOK, Kirsten A.; HUSTON, George Ryan; KINNEY, Michael. Managing earning by manipulation production: the effects of cost structure and inventory evaluation method. Working Paper, 2007.

COOPER, Robin; SLAGMULDER, Regine. Strategic cost management: expanding scope and boundaries. Cost Management, ABI/INFORM Global, Boston, v. 17, n. 1, Jan./Feb. 2003a.

CSCMP - Council of Supply Management Professionals. CSCMP suggested minimum supply chain benchmarking standards. Lombard: eBook edition, 2010.

DAMODARAN, Aswath. Estimating equity risk parameters. Working Papers Series. New York: Stern School of Business, New York University, 1999.

DEO, Prakash S. Setting financial objectives for a firm: part I: a framework. Corporate Finance Review, [S.1.], v. 14, n. 5, 2010a.

Setting financial objectives for a firm: part II: performance measures. Corporate Finance Review, [S.1.], v. 14, n. 5, 2010 b.

DOANE, David P.; SEWARD, Lori E. Estatística aplicada à administração e à economia. São Paulo: McGraw-Hill, 2008.

DUARTE, Patrícia Cristina.; LAMOUNIER, Wagner Moura; TAKAMATSU, Renata Turola. Modelos econométricos para dados em painel: aspectos teóricos e exemplos de aplicação à pesquisa em contabilidade e finanças. In: CONGRESSO USP DE INICIAÇÃO CIENTÍFICA EM CONTABILIDADE, 4, São Paulo, 2007.

FIFER, Robert M. Cost benchmarking functions in the value chain. Planning Review, [S.1.], p. 18-27, May./June. 1989.

FLEURY, Afonso Carlos Corrêa; NAKANO, Davi Noboru; GARCIA, Renato de Castro. Uma análise da cadeia têxtil e confecções brasileira à luz da formação de cadeias globais de 
produção. In: SENAI/CETIQT Globalização da economia têxtil e de confecções brasileira: empresários, governo e academia reunidos pelo futuro do setor. Rio de Janeiro, 2007.

FOSTER, George; YOUNG, S. Mark. Frontiers of management accounting research. Journal of Management Accounting Research, Sarasota, v. 9, p. 63, 1997.

FREZATTI, Fábio. Orçamento empresarial: planejamento e controle gerencial. São Paulo: Atlas, 2000.

GHOSHAL, Sumantra; WESTNEY, D. Eleanor. Organizing competitor analysis system. Strategic Management Journal, [S.1.], 1991.

GITMAN, Lawrence J. Princípios de administração financeira. 7. ed. São Paulo: Habra, 1997.

GOLDSTEIN, Matt. Supermarkets: reinvention is in store. Chain Store Age, ABI/INFORM Global, New York, v. 80, n. 8; Aug. 2004.

GUERRA, Almir R.; ROCHA, Welington; CORRAR, Luiz J. Análise do impacto das variações de receita no lucro das empresas com diferentes estruturas de custo. Revista de Administração, São Paulo, v. 42, n. 2, 2007.

GUERREIRO, Reinaldo. Estruturação de sistemas de custos para a gestão da rentabilidade. São Paulo: Atlas, 2011.

GUILDING, Chris. Competitor-focused accounting: an exploratory note. Accounting Organization and Society, [S.1.], v. 24, n. 7, 1999.

GUJARATI, Damodar. Econometria básica. 4. ed. Rio de Janeiro. Elsevier, 2006. (Capítulo de livro: Capítulo 13, dados em painel).

HANSEN, Stephen C. Cost analysis, cost reduction and competition. Journal of Management Accounting Research, Sarasota, v. 10, p. 181, 1998.

HEINEN, Christoph.; HOFFJAN, Andreas. The strategy relevance of competitor cost assessment. An empirical study regarding competitor accounting. Jamar, [S.1.], v. 3, n. 1, 2005.

HESFORD, James Wesley. Determinants of the use of competitor's accounting information by competitive inteligence professionals. Los Angeles: University of Southern California, 1998.

HILTON, Ronald W. Managerial accounting. Creating value in a dynamic business environment. 7. ed. New York: McGraw-Hill, 2008. 
HUMBERG, Mário Humberto. Santista Têxtil: uma história de inovações, 75 anos. PESSOA, M. H. E. C (Org.). São Paulo: CLA Comunicações, 2004.

IMA. INSTITUTE OF MANAGEMENT ACCOUNTANTS. Developing comprehensive competitive inteligence. Statements on Management Accounting, Montvale: IMA, 1996.

JANOT, Márcio Magalhães. Modelos de previsão de insolvência bancária no Brasil. Trabalhos para Discussão 13, Banco Central do Brasil, Brasília, Mar. 2001.

JENSEN, Michel C. Value Maximization and the corporate objective function. Harvard Business School, Working paper, [S.1.], 2000.

JENSEN, Michael C., MECKLING, Willian H. Theory of the firm: managerial behavior, agency costs, and ownership structure. Journal of Financial Economics, Amsterdam, v. 3, p. 305-360, 1976.

KALLAPUR, Sanjay; ELDENBURG, Leslie. Uncertainty, real options, and cost behavior: evidences from Washington state hospitals. Working Paper, [S.1.], 2005.

KANITZ, Stephen C. Como prever falências. São Paulo: McGraw-Hill, 1978.

LACHTERMACHER, Gerson; ESPENCHITTI, Dilson Godoi. Previsão de falência de empresas: estudo de generalização de redes neurais. In: ENCONTRO ANUAL DA ANPAD. Foz do Iguaçu, 22. ANPAD, p. 178-179, 1998.

LAMBERT, Douglas M.; BURDUROGLU, Renan. Measuring and selling the value of logistics. International Journal of Logistics Management, [S.1.], v. 11, n. 1, 2000.

LANDGRAF, Fernando; TSCHIPTSCHIN, André P.; GOLDENSTEIN, Hélio. Notas sobre a história da metalurgia no Brasil. In: VARGAS, Milton (org.). História da técnica da tecnologia no Brasil. São Paulo: Unesp, 1995. Disponível em: <http://www.pmt.usp.br/notas/notas.htm>. Acesso em: 14/04/2011.

LOPES, Alexsandro B.; MARTINS, Eliseu. Teoria da contabilidade: uma nova abordagem. São Paulo: Atlas, 2005.

MAHER, Michael. Contabilidade de custos: criando valor para a administração. São Paulo: Atlas, 2001.

MARTINS, Eliseu. Contabilidade de custos. São Paulo: Atlas, 2010. 
MARTINS, Eliseu; ROCHA, Welington. Métodos de custeio comparados: custos e margens analisados sob diferentes perspectivas. São Paulo: Atlas, 2010.

MARTINS, Gilberto de Andrade; PAULI, Sergi; KANAZAWA, Erika Yukie. Manual para formatação e edição de dissertações e teses. São Paulo: 2004. Disponível em: $<$ http://www.erudito.fea.usp.br/portalfea/Default.aspx?idPagina=1833>. Acesso em: 09/06/2010.

MARTINS, Gilberto Andrade; THEÓPHILO, Carlos Renato. Metodologia da investigação científica para Ciências Sociais Aplicadas. São Paulo: Atlas, 2009.

MAUER, David C.; OTT, Steven H. Investment under uncertainty: the case of replacement investment decisions. Journal of Financial and Quantitative Analysis, [S.1.], v. 26, 1995.

MILANI, Marco Antônio Figueiredo; ROCHA, Welington; CORRAR, Luis João. Informações sobre concorrentes: um estudo exploratório. In: CONGRESSO USP, São Paulo, 2007.

MILLER, Jeffrey G.; VOLLMANN, Thomas E. The hiden factory. Harvard Business Review, Boston, n. 85510, 1985.

PADILHA, Maria L. M. L. Indicadores de desenvolvimento sustentável para o setor têxtil. São Paulo. 2009. Tese (Doutor em Saúde Pública) - Faculdade de Saúde Pública, Universidade de São Paulo.

PENROSE, Edith T. The theory of the growth of the firm. Oxford: Blackwell, 1959

PENROSE, Edith T. A teoria do crescimento da firma. Unicamp: Campinas, 2006.

PIZZINI, Mina J. The relation between cost-system design, manager's evaluations of the relevance and usefulness of cost data, and financial performance: an empirical study of US hospitals. Accounting Organizations and Society, [S.1.], v. 31, 2006.

PORTER, Michael. A vantagem competitiva das nações. 7. ed. Rio de Janeiro: Campus, 1989.

RICHARDSON, Roberto Jarry. Pesquisa social: métodos e técnicas. 3. ed. São Paulo: Atlas, 1999.

ROSS, Stephen A.; JORDAN, Bradford D.; WESTERFIELD, Randolph W. Administração financeira. 8. ed. São Paulo: McGraw-Hill, 2008.

SAKURAI, Michiaru. Gerenciamento integrado de custos. São Paulo: Atlas, 1997. 
SAMUELSON, Paul A.; NORDHAUS, William D. Economia. Lisboa: McGraw Hill, 1993.

SANTOS, Paulo Cezar Consentino dos. Uma contribuição ao estudo da influência dos custos fixos e da sua correlação com os lucros bruto e operacional das empresas siderúrgicas brasileiras. São Paulo. 2002. Dissertação (Mestrado em Contabilidade) Faculdade de Economia, Administração e Contabilidade, Universidade de São Paulo.

SANTOS, Rodrigo Pinto dos. Análise de custos dos concorrentes: um estudo exploratório entre teoria e prática. São Paulo. 2010. Dissertação (Mestrado em Contabilidade) - Faculdade de Economia, Administração e Contabilidade, Universidade de São Paulo.

SHANK, John K. Strategic cost management: new wine or just new bottles? Journal of Management Accounting, [S.1.], v. 1, 1989.

SHANK, John K.; GOVINDARAJAN, Vijay. Strategic cost management - the new tool for competitive advantage. New York: The Free Press, 1993.

SHARMA, Anil K.; KUMAR, Satish. Economic Value Added (EVA). Literature review and relevant issues. International Journal of Economics and Finance, [S.1.], v. 2, n. 2, May. 2010.

SILVEIRA, Alexandre di Miceli da; YOSHINAGA, Claudia Emiko; BORBA, Paulo da Rocha Ferreira. Crítica à teoria dos stakeholders como função-objetivo corporativa. Caderno de Pesquisas em Administração, São Paulo, v. 10, n. 4, out./34-dez. 2005.

SORO, Torna Omar. Cost structure and regulation in the telecommunications. California, 2006. Dissertation presented to the Faculty of the Graduate School University of Southern California.

STOCK, James H.; WATSON, Mark, W. Econometria. São Paulo: Pearson, 2004.

SUBRAMANIAN, Ram; ISHAK, Samir T. Competitor analysis practices of US companies: An empirical investigation. Management International Review, ABI/INFORM Global, Wiesbaden, v. 38, n. 1, First Quarter 1998.

TEIXEIRA, Francisco. A história da indústria têxtil paulistana. São Paulo: Arteneios, 2007.

VALOR ON LINE. CSN terceiriza logística em Volta Redonda. 2008. Disponível em: $<$ http://www.intelog.net>. Acesso em: 07/07/2011.

VANDERBECK, Edward J.; NAGY.Charles F. Contabilidade de custos. São Paulo: Pioneira Thomson Learning, 2003. 
VAZ, Samir L. A siderurgia brasileira a carvão vegetal. São Paulo. 2010. Dissertação (Mestrado em Administração) - Faculdade de Economia, Administração e Contabilidade. Universidade de São Paulo.

VIEIRA, Deodete P. Facilitadores no processo de inovação tecnológica. Santa Catarina. 1995. Tese (Doutorado em Engenharia da Produção) - Universidade Federal de Santa Catarina.

VITAL, Marcos H.; PINTO, Marcos A. Condições para sustentabilidade da produção de carvão vegetal para fabricação de ferro-gusa no Brasil. In: Banco Nacional de Desenvolvimento Econômico e Social (BNDES). BNDES Setorial. 2009, p. 237-297. Disponível em: <http://www.bndes.org.br>. Acesso em: 14/04/2011.

WILSON, Richard. Competitor analysis. Management Accounting, [S.1.], April, 1994.

WOOLDRIDGE, Jeffrey M. Introdução à econometria: uma abordagem moderna. São Paulo: Pioneira Thomson Learning, 2006.

YIN, Robert K. Estudo de caso: planejamento e métodos. 2. ed. São Paulo: Bookman, 2001.

\section{SITES PESQUISADOS}

ABIT - Associação Brasileira da Indústria Têxtil e de Confecções - site da entidade representativa das empresas brasileiras do setor têxtil. Disponível em: $<$ htpp://www.abit.org.br>. Acesso em: 12/04/2011.

CAPES - site de pesquisa de periódicos. Disponível em: $<$ http://www.periodicos.capes.gov.br>. Acesso em: diversas datas, desde 07/10/2009.

INSTITUTO AÇO BRASIL - site da entidade representativa das empresas brasileiras produtora de aço. Disponível em: <http://www.acobrasil.org.br>. Acesso em: abril/2011.

ISI - site de pesquisa de periódicos. Disponível em: <http://apps.isiknowledge.com>. Acesso em: diversas datas, desde 07/10/2009.

JSTOR - site de pesquisa de periódicos. Disponível em: <http://www.jstor.org $>$. Acesso em: diversas datas, desde 07/10/2009.

PROQUEST - site de pesquisa de periódicos. Disponível em: <http://proquest.umi.com>. Acesso em: diversas datas, desde 07/10/2009.

SCIENCEDIRECT - site de pesquisa de periódicos. Disponível em: $<$ http://www.sciencedirect.com>. Acesso em: diversas datas, desde 07/10/2009. 


\section{APÊNDICES}

APÊNDICE 1 - TESTE DE OUTLIERS

APÊNDICE 2 - MODELO POOLING

APÊNDICE 3 - MODELO EFEITO FIXO

APÊNDICE 4 - MODELO EFEITO ALEATÓRIO

APÊNDICE 5 - INDICADORES DO SETOR TÊXTIL

APÊNDICE 6 - INDICADORES DO SETOR SIDERURGIA/METALURGIA 
APÊNDICE 1 - TESTE DE OUTLIERS

Setor TÊXTIL

\begin{tabular}{|c|c|c|c|c|c|c|}
\hline Nome & Setor & Imob05 & Imob06 & Imob07 & Imob08 & Imob09 \\
\hline Alpargatas & Têxtil & 271.716 & 201.192 & 223.608 & 333.798 & 293.108 \\
\hline Botucatu Tex & Têxtil & 17.057 & 41.579 & 40.341 & 39.313 & 32.060 \\
\hline Buettner & Têxtil & 32.027 & 28.875 & 25.959 & 23.489 & 21.437 \\
\hline Cambuci & Têxtil & 40.200 & 44.958 & 48.133 & 47.995 & 37.554 \\
\hline Cedro & Têxtil & 200.627 & 199.861 & 188.741 & 172.735 & 167.258 \\
\hline Cia Hering & Têxtil & 216.480 & 212.039 & 221.744 & 167.079 & 175.245 \\
\hline Coteminas & Têxtil & 1.192 .862 & 1.636 .194 & 1.497 .525 & 1.403 .958 & 1.300 .297 \\
\hline Cremer & Têxtil & 42.501 & 36.963 & 39.406 & 46.346 & 46.925 \\
\hline Dohler & Têxtil & 63.723 & 52.055 & 42.440 & 35.494 & 41.868 \\
\hline Encorpar & Têxtil & 7.093 & 7.271 & 7.078 & 6.962 & 7.075 \\
\hline Fab C Renaux & Têxtil & 90.989 & 84.939 & 79.756 & 75.428 & 70.197 \\
\hline Grendene & Têxtil & 181.603 & 157.413 & 153.854 & 152.414 & 179.638 \\
\hline Guararapes & Têxtil & 384.947 & 721.835 & 821.493 & 930.221 & 963.047 \\
\hline Ind Cataguas & Têxtil & 52.774 & 66.152 & 72.627 & 72.873 & 72.589 \\
\hline Karsten & Têxtil & 65.862 & 60.104 & 53.155 & 68.098 & 66.136 \\
\hline Marisol & Têxtil & 101.695 & 102.017 & 111.958 & 118.167 & 115.926 \\
\hline Pettenati & Têxtil & 55.625 & 53.744 & 63.634 & 142.465 & 121.739 \\
\hline Santanense & Têxtil & 103.402 & 108.127 & 105.943 & 101.440 & 95.060 \\
\hline Schlosser & Têxtil & 40.935 & 37.641 & 34.712 & 10.983 & 11.312 \\
\hline Tecel S Jose & Têxtil & 55.146 & 50.643 & 46.095 & 29.284 & 28.215 \\
\hline Teka & Têxtil & 311.659 & 283.737 & 266.614 & 249.482 & 226.634 \\
\hline Tex Renaux & Têxtil & 47.373 & 44.516 & 42.440 & 41.487 & 54.534 \\
\hline Vicunha Text & Têxtil & 612.793 & 853.098 & 809.409 & 721.899 & 658.788 \\
\hline Vulcabras & Têxtil & 110.461 & 108.884 & 222.848 & 277.682 & 281.944 \\
\hline Wembley & Têxtil & 1.202 .709 & 1.644 .144 & 1.505 .244 & 1.411 .523 & 1.308 .263 \\
\hline
\end{tabular}

\section{Boxplot Setor Têxtil}
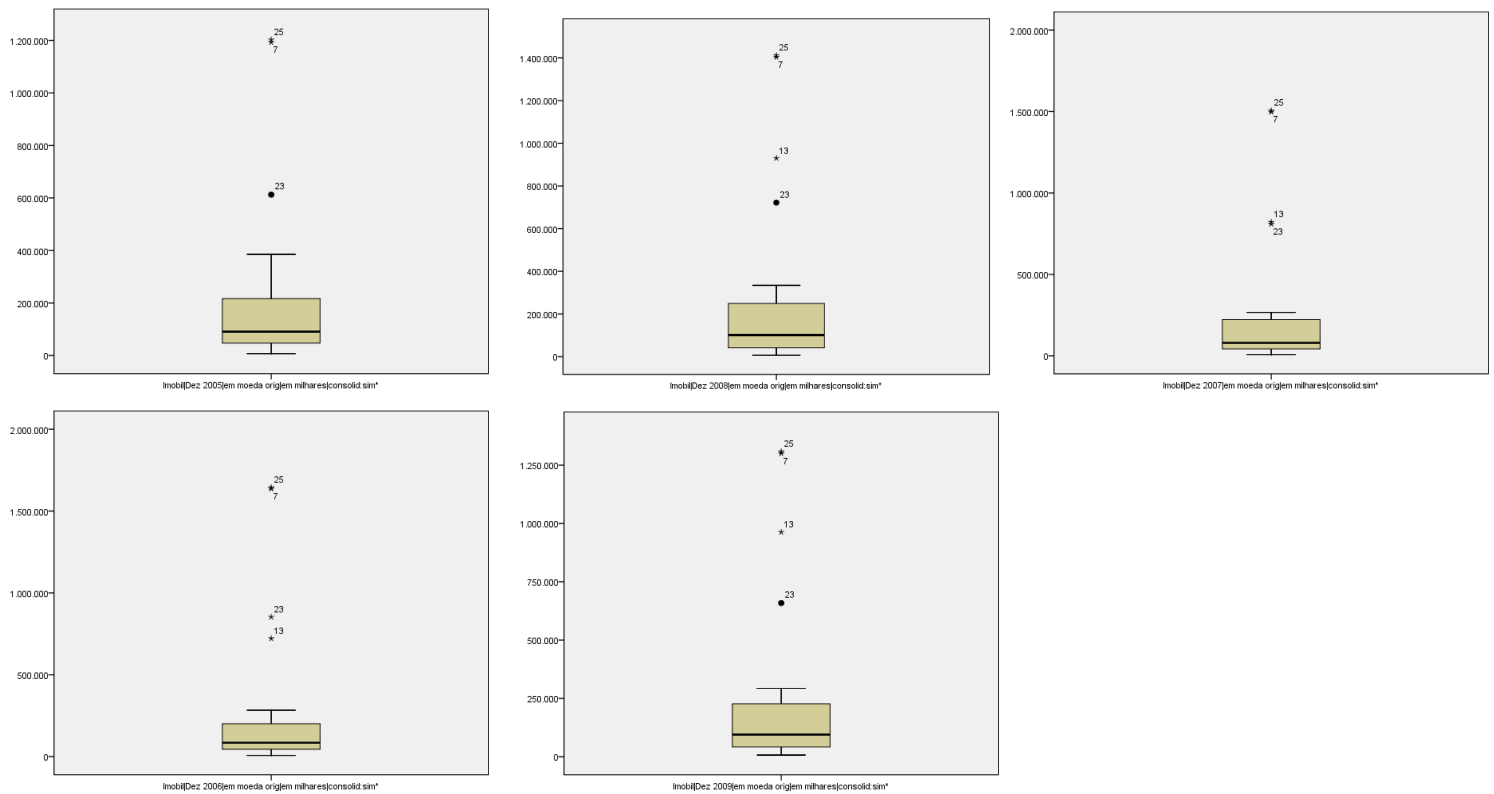
Setor SIDERURGIA/METALURGIA

\begin{tabular}{|l|l|c|c|c|r|r|}
\multicolumn{2}{c}{ Nome } & \multicolumn{2}{c}{ Setor } & \multicolumn{1}{c}{ Imob05 } & \multicolumn{1}{c|}{ Imob07 } & \multicolumn{1}{c|}{ Imob08 } \\
\hline Aco Altona & Siderur \& Metalur & 44.682 & 48.873 & 52.460 & 53.621 & 50.940 \\
\hline Aliperti & Siderur \& Metalur & 62.538 & 64.052 & 64.063 & 62.141 & 61.693 \\
\hline Confab & Siderur \& Metalur & 266.284 & 267.899 & 240.178 & 226.154 & 243.078 \\
\hline Ferbasa & Siderur \& Metalur & 207.573 & 217.633 & 235.434 & 298.572 & 330.968 \\
\hline Fibam & Siderur \& Metalur & 12.763 & 12.806 & 11.731 & 17.804 & 17.917 \\
\hline Forjas Taurus & Siderur \& Metalur & 87.771 & 109.848 & 120.662 & 159.500 & 179.572 \\
\hline Gerdau & Siderur \& Metalur & 8.693 .501 & 11.183 .651 & 15.827 .944 & 20.054 .747 & 16.731 .101 \\
\hline Gerdau Met & Siderur \& Metalur & 8.694 .958 & 11.184 .940 & 15.829 .091 & 20.053 .348 & 16.732 .030 \\
\hline Haga S/A & Siderur \& Metalur & 5.992 & 5.903 & 5.668 & 6.681 & 7.477 \\
\hline Kepler Weber & Siderur \& Metalur & 143.570 & 132.070 & 119.878 & 106.414 & 97.594 \\
\hline Lupatech & Siderur \& Metalur & 49.885 & 71.908 & 183.682 & 295.781 & 317.960 \\
\hline Mangels Indl & Siderur \& Metalur & 192.368 & 176.944 & 201.016 & 259.897 & 288.929 \\
\hline Met Duque & Siderur \& Metalur & 43.495 & 46.600 & 56.565 & 109.484 & 107.527 \\
\hline Metal Iguacu & Siderur \& Metalur & 18.316 & 20.538 & 20.574 & 22.642 & 21.612 \\
\hline Metisa & Siderur \& Metalur & 20.169 & 20.415 & 24.418 & 36.073 & 38.801 \\
\hline Mundial & Siderur \& Metalur & 259.929 & 244.102 & 305.168 & 296.302 & 294.267 \\
\hline Panatlantica & Siderur \& Metalur & 16.978 & 19.635 & 26.118 & 29.804 & 41.253 \\
\hline Paranapanema & Siderur \& Metalur & 834.765 & 853.206 & 930.145 & 678.134 & 656.789 \\
\hline Rimet & Siderur \& Metalur & 12.006 & 18.681 & 23.824 & 10.725 & 24.557 \\
\hline Sid Nacional & Siderur \& Metalur & 13.638 .200 & 13.948 .261 & 15.295 .642 & 10.083 .777 & 11.145 .530 \\
\hline Tekno & Siderur \& Metalur & 18.701 & 16.858 & 18.165 & 20.047 & 17.857 \\
\hline Usiminas & Siderur \& Metalur & 8.648 .782 & 8.471 .965 & 9.011 .407 & 10.339 .709 & 11.950 .117 \\
\hline
\end{tabular}

Outliers eliminados no setor Têxtil

\section{Boxplot - Siderurgia/Metalurgia}
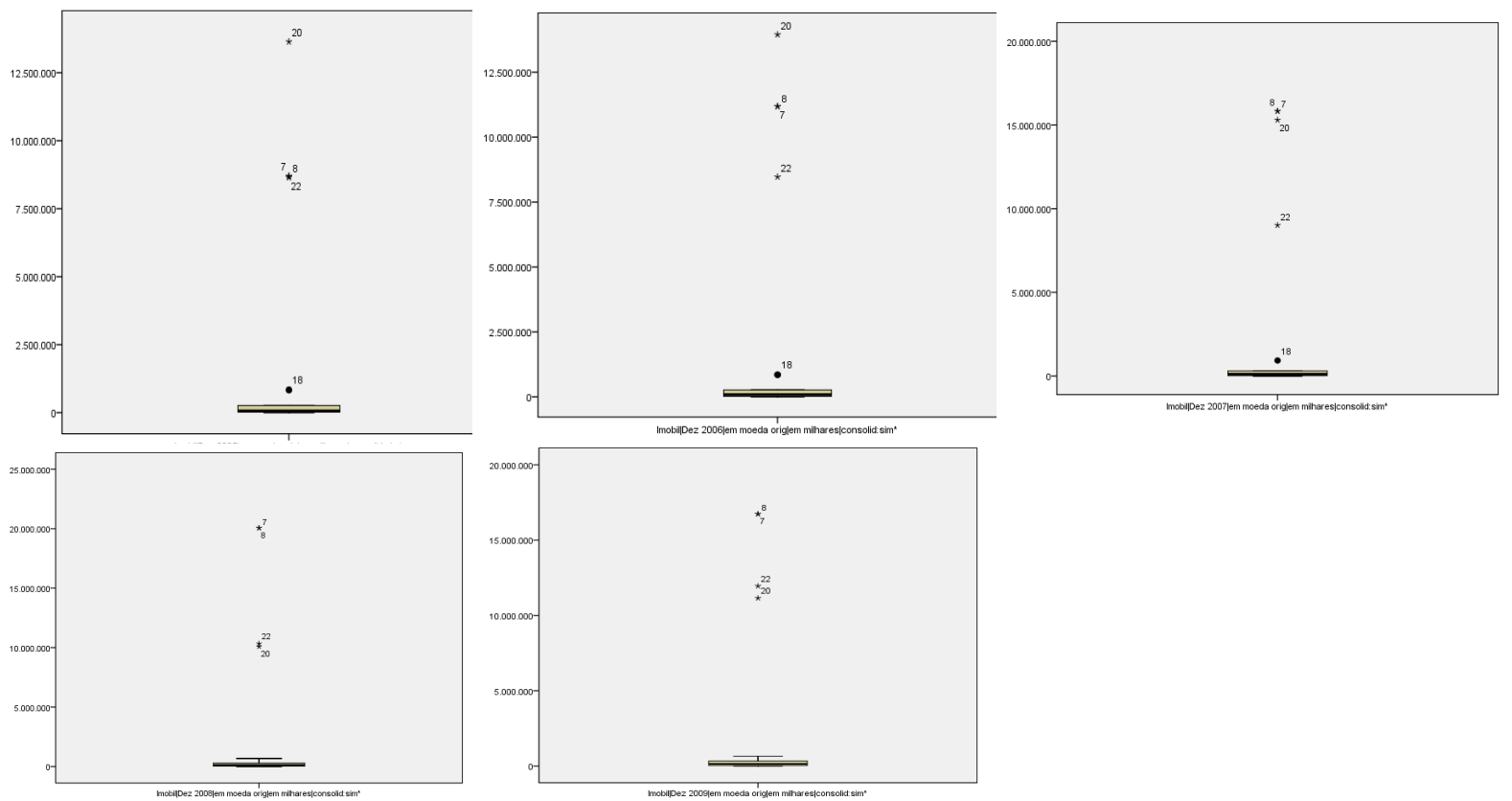


\section{APÊNDICE 2 - MODELO POOLING}

\section{Setor Têxtil}

\begin{tabular}{|c|c|c|c|c|c|}
\hline \multicolumn{6}{|c|}{ Dependent Variable: LNCDT? } \\
\hline \multicolumn{6}{|c|}{ Method: Pooled Least Squares } \\
\hline \multicolumn{6}{|c|}{ Date: 06/30/11 Time: 22:02 } \\
\hline \multicolumn{6}{|l|}{ Sample: 20052009} \\
\hline \multicolumn{6}{|c|}{ Included observations: 5} \\
\hline \multicolumn{6}{|c|}{ Cross-sections included: 19} \\
\hline \multicolumn{6}{|c|}{ Total pool (balanced) observations: 95} \\
\hline Variable & Coefficient & Std. Error & & tatistic & Prob. \\
\hline LNREC? & 0,88009 & & 0,02154 & 4086368,00000 & 0,00000 \\
\hline LNIMOB? & 0,01285 & & 0,03123 & 0,41149 & 0,68170 \\
\hline $\mathrm{C}$ & 1,31540 & & 0,24420 & 5386530,00000 & 0,00000 \\
\hline R-squared & 0,97459 & Mean de & ent var & & 12,15008 \\
\hline Adjusted R-squared & 0,97403 & S.D. dep & at var & & 1,05139 \\
\hline S.E. of regression & 0,16942 & Akaike i & iterion & & $-0,68175$ \\
\hline Sum squared resid & 2,64082 & Schwarz & rion & & $-0,60111$ \\
\hline Log likelihood & 35,38331 & F-statisti & & & 1763,98600 \\
\hline Durbin-Watson stat & 0,81285 & $\operatorname{Prob}(\mathrm{F}-\mathrm{s}$ & & & 0,00000 \\
\hline
\end{tabular}

No modelo pooling do setor Têxtil é gerada uma equação geral para todas as empresas da amostra. Apesar de o modelo ser significante estatisticamente, o teste de redundância para este setor demonstrou que o modelo de efeitos fixos é mais adequado.

\section{Setor Siderurgia/Metalurgia}

\begin{tabular}{|c|c|c|c|c|c|}
\hline \multicolumn{6}{|c|}{ Dependent Variable: LNCDT? } \\
\hline \multicolumn{6}{|c|}{ Method: Pooled Least Squares } \\
\hline \multicolumn{6}{|c|}{ Date: 06/30/11 Time: $22: 16$} \\
\hline \multicolumn{6}{|l|}{ Sample: 20052009} \\
\hline \multicolumn{6}{|c|}{ Included observations: 5} \\
\hline \multicolumn{6}{|c|}{ Cross-sections included: 14} \\
\hline \multicolumn{6}{|c|}{ Total pool (balanced) observations: 70} \\
\hline Variable & Coefficient & Std. Error & t-Statistic & $\operatorname{Pr}$ & \\
\hline LNREC? & 0,88939 & 0.020517 & 43,34891 & & - \\
\hline LNIMOB? & 0,04019 & 0.019216 & 2,09164 & & 0,04030 \\
\hline $\mathrm{C}$ & 0,81972 & 0.167661 & 48,89147 & & - \\
\hline R-squared & 0,98529 & \multicolumn{2}{|c|}{ Mean dependent var } & & 11,95544 \\
\hline Adjusted R-squared & 0,98485 & \multicolumn{2}{|c|}{ S.D. dependent var } & & 0,96351 \\
\hline S.E. of regression & 0,11859 & \multicolumn{2}{|c|}{ Akaike info criterion } & - & 1,38443 \\
\hline Sum squared resid & 0,94221 & \multicolumn{2}{|c|}{ Schwarz criterion } & - & 1,28807 \\
\hline Log likelihood & 51,45510 & \multicolumn{2}{|c|}{ F-statistic } & & 2243,998 \\
\hline Durbin-Watson stat & 1,07126 & \multicolumn{2}{|c|}{ Prob(F-statistic) } & & - \\
\hline
\end{tabular}

No modelo pooling do setor de Siderurgia/Metalurgia é gerada uma equação geral para todas as empresas da amostra. Apesar de o modelo ser significante estatisticamente, o teste de redundância para este setor demonstrou que o modelo de efeitos fixos é mais adequado. 


\section{APÊNDICE 3 - MODELO EFEITO FIXO}

\section{Setor Têxtil}

Dependent Variable: LNCDT?

Method: Pooled Least Squares

Date: 06/30/11 Time: 23:06

Sample: 20052009

Included observations: 5

Cross-sections included: 19

Total pool (balanced) observations: 95

Variable

Coefficient Std

0,792863

Std. Error t-Statistic

Prob.

LNREC?

$-0,037139$

0,049418

16,0441

0,0000

LNIMOB?

2,937224

0,063564

$-0,5843$

0,5608

$\mathrm{C}$

0,819045

3,5862

0,0006

Fixed Effects (Cross)

$1-\mathrm{C}$

0,324504

2--C

$-0,068248$

$-0,042697$

$-0,062454$

0,125995

$-0,000652$

$-0,004305$

0,035489

$-0,125747$

0,262941

$-0,145992$

0,030681

$-0,147721$

$-0,077173$

$-0,058640$

$-0,207649$

0,277296

$-0,339019$

0,223391

Effects Specification

Cross-section fixed (dummy variables)

R-squared

0,985058 Mean dependent var

Adjusted R-squared

0,981020

S.D. dependent var

S.E. of regression

0,144849 Akaike info criterion

Sum squared resid

1,552613

Schwarz criterion

Log likelihood

60,612860

F-statistic

243,9247

Durbin-Watson stat

1,339009 Prob(F-statistic)

0,0000

No modelo de efeito fixo do setor Têxtil, o intercepto de cada empresa é composto por um intercepto geral $(2,937)$ e um intercepto individual para as 19 empresas da amostra. No entanto, percebeu-se que a variável IMOB não foi significativa, assim, decidiu-se excluir esse parâmetro e rodar novamente o modelo. 


\begin{tabular}{|c|c|c|c|c|}
\hline \multicolumn{5}{|c|}{ Dependent Variable: LNCDT? } \\
\hline \multicolumn{5}{|c|}{ Method: Pooled Least Squares } \\
\hline \multicolumn{5}{|c|}{ Date: 06/30/11 Time: $23: 12$} \\
\hline \multicolumn{5}{|l|}{ Sample: 20052009} \\
\hline \multicolumn{5}{|c|}{ Included observations: 5} \\
\hline \multicolumn{5}{|c|}{ Cross-sections included: 19} \\
\hline \multicolumn{5}{|c|}{ Total pool (balanced) observations: 95} \\
\hline Variable & $\begin{array}{l}\text { Coefficien } \\
\mathrm{t}\end{array}$ & Std. Error & $\mathrm{t}$-Statistic & Prob. \\
\hline LNREC? & 0,786107 & 0,047834 & 16,43389 & 0,0000 \\
\hline $\mathrm{C}$ & 2,601562 & 0,581214 & 4,47608 & 0,0000 \\
\hline \multicolumn{5}{|l|}{ Fixed Effects (Cross) } \\
\hline $1--\mathrm{C}$ & \multicolumn{4}{|l|}{0,29318} \\
\hline 2--C & \multicolumn{4}{|l|}{$-0,04868$} \\
\hline $3--\mathrm{C}$ & \multicolumn{4}{|l|}{$-0,00464$} \\
\hline $4--\mathrm{C}$ & \multicolumn{4}{|l|}{$-0,04227$} \\
\hline 5--C & \multicolumn{4}{|l|}{0,09754} \\
\hline 6--C & \multicolumn{4}{|l|}{$-0,03017$} \\
\hline 7--C & \multicolumn{4}{|l|}{0,02050} \\
\hline 8--C & \multicolumn{4}{|l|}{0,05468} \\
\hline 9--C & \multicolumn{4}{|l|}{$-0,13448$} \\
\hline $10--\mathrm{C}$ & \multicolumn{4}{|l|}{0,24724} \\
\hline $11--\mathrm{C}$ & \multicolumn{4}{|l|}{$-0,14240$} \\
\hline $12--\mathrm{C}$ & \multicolumn{4}{|l|}{0,04146} \\
\hline 13--C & \multicolumn{4}{|l|}{$-0,15229$} \\
\hline 14--C & \multicolumn{4}{|l|}{$-0,08612$} \\
\hline 15--C & \multicolumn{4}{|l|}{$-0,02510$} \\
\hline 16--C & \multicolumn{4}{|l|}{$-0,19703$} \\
\hline 17--C & \multicolumn{4}{|l|}{0,23395} \\
\hline $18--\mathrm{C}$ & \multicolumn{4}{|l|}{$-0,32632$} \\
\hline 19--C & \multicolumn{4}{|l|}{0,20096} \\
\hline & \multicolumn{4}{|c|}{ Effects Specification } \\
\hline Cross-section fixed ( & ummy varial & les) & & \\
\hline R-squared & 0,984989 & Mean dep & pendent var & 12,1501 \\
\hline Adjusted R-squared & 0,981186 & S.D. depe & endent var & 1,0514 \\
\hline S.E. of regression & 0,144212 & Akaike in & fo criterion & $-0,8504$ \\
\hline Sum squared resid & 1,55978 & Schwarz & criterion & $-0,3127$ \\
\hline Log likelihood & 60,39423 & F-statistic & & 259,0194 \\
\hline Durbin-Watson stat & 1,32649 & $\operatorname{Prob}(\mathrm{F}-\mathrm{st}$ & tatistic) & 0,0000 \\
\hline
\end{tabular}

No modelo de efeito fixo do setor Têxtil, o custo e despesa fixo é mensurado exclusivamente por meio do intercepto do modelo (geral + individual das empresas), já que não há correlação significante entre a variação do IMOB e a variação do CDT. Já o custo e despesa variável é mensurado pela variação da receita líquida. 


\section{Setor Siderurgia/Metalurgia}

\begin{tabular}{|c|c|c|c|c|c|}
\hline \multicolumn{6}{|c|}{ Dependent Variable: LNCDT? } \\
\hline \multicolumn{6}{|c|}{ Method: Pooled Least Squares } \\
\hline \multicolumn{6}{|c|}{ Date: 06/30/11 Time: $23: 17$} \\
\hline \multicolumn{6}{|l|}{ Sample: 20052009} \\
\hline \multicolumn{6}{|c|}{ Included observations: 5} \\
\hline \multicolumn{6}{|c|}{ Cross-sections included: 14} \\
\hline \multicolumn{6}{|c|}{ Total pool (balanced) observations: 70} \\
\hline Variable & Coefficient & Std. Error & t-Statistic & Prob. & \\
\hline LNREC? & 0,684835 & 0,047709 & 14,354290 & & 0,000000 \\
\hline LNIMOB? & 0,124230 & 0,044851 & 2,769834 & & 0,007700 \\
\hline $\mathrm{C}$ & 2,385114 & 0,620079 & 3,846468 & & 0,000300 \\
\hline \multicolumn{6}{|c|}{ Fixed Effects (Cross) } \\
\hline $1--\mathrm{C}$ & $-0,11567$ & & & & \\
\hline $2--\mathrm{C}$ & $-0,21520$ & & & & \\
\hline $3--\mathrm{C}$ & 0,35691 & & & & \\
\hline $4--\mathrm{C}$ & $-0,01817$ & & & & \\
\hline $5--\mathrm{C}$ & $-0,04397$ & & & & \\
\hline 6--C & 0,05099 & & & & \\
\hline 7--C & $-0,34315$ & & & & \\
\hline 8--C & 0,10589 & & & & \\
\hline 9--C & $-0,19841$ & & & & \\
\hline $10--\mathrm{C}$ & 0,00033 & & & & \\
\hline $11--\mathrm{C}$ & 0,00082 & & & & \\
\hline $12--\mathrm{C}$ & 0,24964 & & & & \\
\hline 13--C & 0,19919 & & & & \\
\hline $14--\mathrm{C}$ & $-0,02920$ & & & & \\
\hline \multicolumn{5}{|c|}{ Effects } & Specification \\
\hline \multicolumn{6}{|c|}{ Cross-section fixed (dummy variables) } \\
\hline \multirow{2}{*}{$\begin{array}{l}\text { R-squared } \\
\text { Adjusted R- } \\
\text { squared }\end{array}$} & 0,995157 & Mean dep & endent var & & 11,955440 \\
\hline & 0,993811 & S,D, depe & ndent var & & 0,963509 \\
\hline \multirow{2}{*}{$\begin{array}{l}\text { S.E. of regression } \\
\text { Sum squared } \\
\text { resid }\end{array}$} & 0,075797 & Akaike in & fo criterion & & $-2,123877$ \\
\hline & 0,310242 & $\begin{array}{l}\text { Schwarz c } \\
\text { F- }\end{array}$ & riterion & & $-1,609935$ \\
\hline Log likelihood & 90,335700 & statistic & & & 739,6967 \\
\hline $\begin{array}{l}\text { Durbin-Watson } \\
\text { stat }\end{array}$ & 2,312350 & Prob(F-sta & tistic) & & 0,000000 \\
\hline
\end{tabular}

Todas as variáveis do modelo de regressão com dados em painel com efeito fixo do setor de Siderurgia/Metalurgia foram significantes, portanto, para este setor, existe uma correlação significativa entre a variação do IMOB e a variação dos CDT. Nesse caso, a parcela de CDF sobre os CDT é composta pelo intercepto individual das 14 empresas mais a variação do IMOB. Já a participação dos CDV é representada pela variação da REC. 


\section{APÊNDICE 4 - MODELO EFEITO ALEATÓRIO}

\section{Setor Têxtil}

\begin{tabular}{|c|c|c|c|c|c|}
\hline \multicolumn{6}{|c|}{ Dependent Variable: LNCDT? } \\
\hline \multicolumn{6}{|c|}{ Method: Pooled EGLS (Cross-section random effects) } \\
\hline \multicolumn{6}{|c|}{ Date: 06/30/11 Time: $23: 21$} \\
\hline \multicolumn{6}{|l|}{ Sample: 20052009} \\
\hline \multicolumn{6}{|c|}{ Included observations: 5} \\
\hline \multicolumn{6}{|c|}{ Cross-sections included: 19} \\
\hline \multicolumn{6}{|c|}{ Total pool (balanced) observations: 95} \\
\hline \multicolumn{6}{|c|}{ Swamy and Arora estimator of component variances } \\
\hline Variable & Coefficient & Std. Error & t-Statistic & & \\
\hline LNREC? & 0,875214 & 0,020003 & & 43,753310 & 0,000000 \\
\hline $\mathrm{C}$ & 1,519212 & 0,244228 & & 6,220474 & 0,000000 \\
\hline \multicolumn{6}{|c|}{ Random Effects (Cross) } \\
\hline $1--\mathrm{C}$ & 0,069085 & & & & \\
\hline 2--C & 0,073396 & & & & \\
\hline 3--C & 0,013902 & & & & \\
\hline $4--\mathrm{C}$ & $-0,020122$ & & & & \\
\hline $5--\mathrm{C}$ & 0,026108 & & & & \\
\hline 6--C & $-0,066385$ & & & & \\
\hline 7--C & $-0,009343$ & & & & \\
\hline $8--\mathrm{C}$ & 0,032413 & & & & \\
\hline 9--C & $-0,025426$ & & & & \\
\hline $10--\mathrm{C}$ & 0,051745 & & & & \\
\hline $11--\mathrm{C}$ & $-0,078878$ & & & & \\
\hline $12--\mathrm{C}$ & 0,000150 & & & & \\
\hline $13--\mathrm{C}$ & $-0,072782$ & & & & \\
\hline $14--\mathrm{C}$ & $-0,071289$ & & & & \\
\hline $15--C$ & 0,076573 & & & & \\
\hline $16--\mathrm{C}$ & $-0,014090$ & & & & \\
\hline $17--C$ & 0,126055 & & & & \\
\hline $18--\mathrm{C}$ & $-0,155208$ & & & & \\
\hline 19--C & 0,044096 & & & & \\
\hline Cross-section randon & S.D. / Rho & & & 0,086353 & 0,263900 \\
\hline Idiosyncratic random & S.D. / Rho & & & 0,144212 & 0,736100 \\
\hline R-squared & 0,952150 & Mean depe & endent var & & 7,270470 \\
\hline Adjusted R-squared & 0,951635 & S,D, depen & ident var & & 0,666952 \\
\hline S.E. of regression & 0,146676 & Sum squar & ed resid & & 2,000788 \\
\hline F-statistic & 1850,566 & Durbin-W & atson stat & & 1,068384 \\
\hline Prob(F-statistic) & 0,000000 & & & & \\
\hline R-squared & 0,974381 & Mean depe & endent var & & 12,15008 \\
\hline Sum squared resid & 2,662037 & Durbin-W & atson stat & & 0,802998 \\
\hline
\end{tabular}

No modelo de efeito aleatório para o setor Têxtil, a variável IMOB também não foi significativa e o modelo foi gerado novamente sem essa variável. Apesar de o modelo de efeito aleatório ser significativo, o teste de Hausman demonstrou que o modelo de efeito fixo é mais adequado para este setor. 


\section{Setor Siderurgia/Metalurgia}

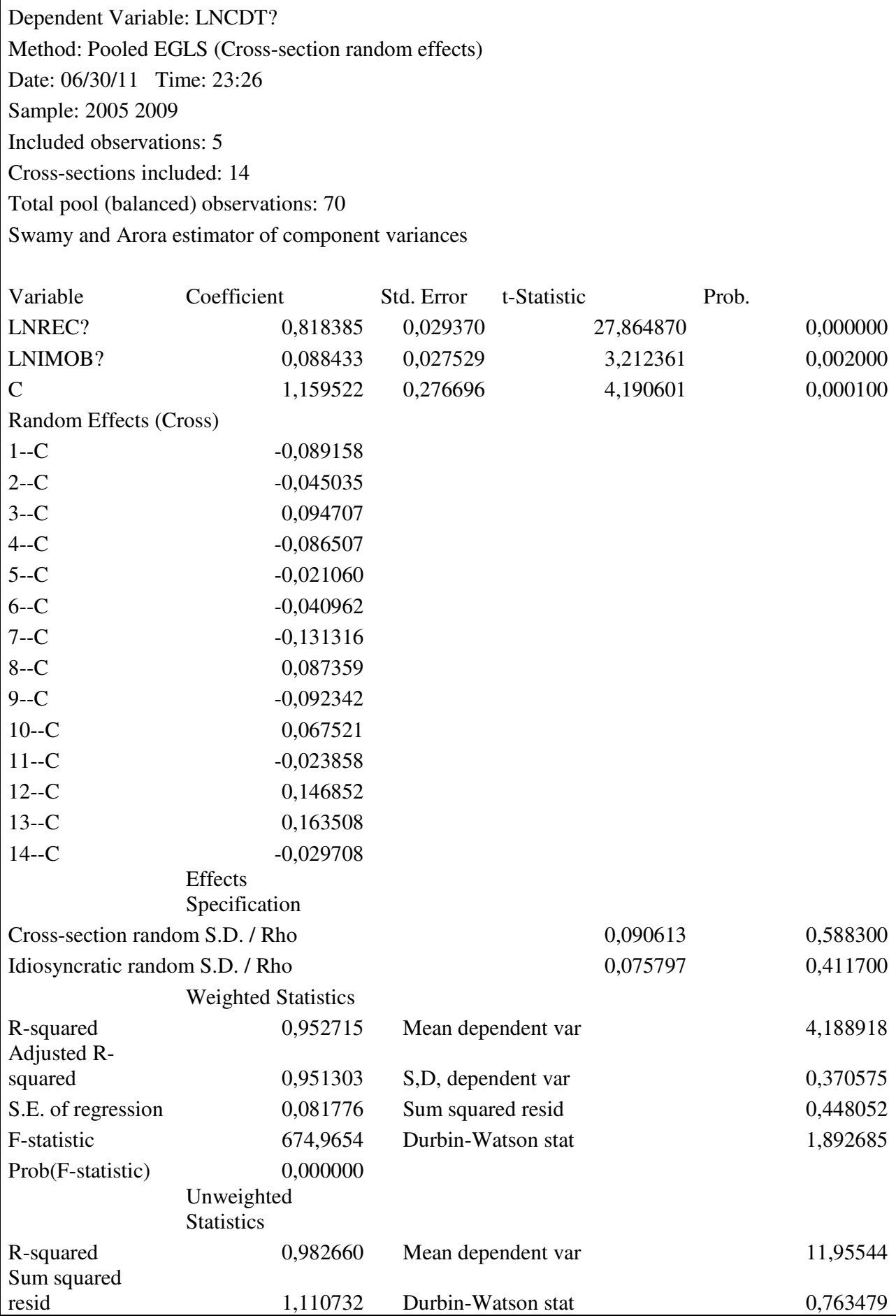

No modelo de efeito aleatório, para o setor de Siderurgia/Metalurgia todas as variáveis foram significativas. Apesar de o modelo de efeito aleatório ser significativo, o teste de Hausman demonstrou que o modelo de efeito fixo é mais adequado para este setor. 


\section{APÊNDICE 5 - INDICADORES DO SETOR TÊXTIL}

SETOR TÊXTIL - GRUPO A

\begin{tabular}{|c|c|c|c|c|c|c|c|}
\hline \multicolumn{7}{|c|}{ GRUPO A - Receita líquida (em milhares de R\$) } \\
\hline \multirow{2}{*}{ Empresa } & $\mathbf{2 0 0 5}$ & $\mathbf{2 0 0 6}$ & $\mathbf{2 0 0 7}$ & $\mathbf{2 0 0 8}$ & $\mathbf{2 0 0 9}$ & $\begin{array}{c}\text { Rec. Liquida } \\
\text { anual média }\end{array}$ & $\begin{array}{c}\text { Cresc. anual } \\
\text { médio } \\
(\mathbf{\%})\end{array}$ \\
\hline $\mathbf{1}$ & $1.357,00$ & $1.358,45$ & $1.289,56$ & $1.658,79$ & $2.005,24$ & $1.533,81$ & $11,14 \%$ \\
\hline $\mathbf{6}$ & 320,30 & 329,98 & 369,24 & 514,92 & 720,95 & 451,08 & $23,60 \%$ \\
\hline $\mathbf{1 0}$ & $1.068,05$ & $1.102,88$ & $1.203,21$ & $1.324,61$ & $1.455,76$ & $1.230,90$ & $8,09 \%$ \\
\hline $\mathbf{1 4}$ & 222,35 & 236,95 & 245,83 & 280,02 & 265,47 & 250,12 & $4,76 \%$ \\
\hline $\mathbf{1 8}$ & 79,98 & 60,82 & 71,69 & 79,04 & 75,11 & 73,33 & $-0,20 \%$ \\
\hline $\mathbf{1 9}$ & 345,57 & 444,65 & 994,23 & $1.628,59$ & $1.597,10$ & $1.002,03$ & $53,54 \%$ \\
\hline Média & $\mathbf{5 6 5 , 5 4}$ & $\mathbf{5 8 8 , 9 5}$ & $\mathbf{6 9 5 , 6 3}$ & $\mathbf{9 1 4 , 3 3}$ & $\mathbf{1 . 0 1 9 , 9 4}$ & $\mathbf{7 5 6 , 8 8}$ & $\mathbf{1 6 , 3 1 \%}$ \\
\hline
\end{tabular}

\begin{tabular}{|c|c|c|c|c|c|c|c|}
\hline \multicolumn{9}{|c|}{ GRUPO A - CDT / REC } \\
\hline Empresa & $\mathbf{2 0 0 5}$ & $\mathbf{2 0 0 6}$ & $\mathbf{2 0 0 7}$ & $\mathbf{2 0 0 8}$ & $\mathbf{2 0 0 9}$ & $\begin{array}{c}\text { CDT anual } \\
\text { média }\end{array}$ & $\begin{array}{c}\text { Cresc. anual } \\
\text { médio }(\%)\end{array}$ \\
\hline $\mathbf{1}$ & 0,87 & 0,79 & 0,88 & 0,89 & 0,88 & 0,86 & $0,36 \%$ \\
\hline $\mathbf{6}$ & 0,81 & 0,88 & 0,82 & 0,83 & 0,74 & 0,82 & $-2,02 \%$ \\
\hline $\mathbf{1 0}$ & 0,88 & 0,86 & 0,85 & 0,82 & 0,90 & 0,86 & $0,66 \%$ \\
\hline $\mathbf{1 4}$ & 0,77 & 0,90 & 0,92 & 0,87 & 0,88 & 0,87 & $3,87 \%$ \\
\hline $\mathbf{1 8}$ & 0,81 & 0,94 & 0,95 & 0,84 & 0,90 & 0,89 & $2,93 \%$ \\
\hline $\mathbf{1 9}$ & 0,84 & 0,90 & 0,87 & 0,85 & 1,01 & 0,90 & $5,03 \%$ \\
\hline Média & $\mathbf{0 , 8 3}$ & $\mathbf{0 , 8 8}$ & $\mathbf{0 , 8 8}$ & $\mathbf{0 , 8 5}$ & $\mathbf{0 , 8 8}$ & $\mathbf{0 , 8 7}$ & $\mathbf{1 , 6 2 \%}$ \\
\hline
\end{tabular}

\begin{tabular}{|c|c|c|c|c|c|c|c|}
\hline \multicolumn{7}{|c|}{ GRUPO A - Estoque / Receita Líquida } \\
\hline Empresa & $\mathbf{2 0 0 5}$ & $\mathbf{2 0 0 6}$ & $\mathbf{2 0 0 7}$ & $\mathbf{2 0 0 8}$ & $\mathbf{2 0 0 9}$ & $\begin{array}{c}\text { Estoque/RL } \\
\text { média }\end{array}$ & $\begin{array}{c}\text { Cresc. anual } \\
\text { médio }(\mathbf{\%})\end{array}$ \\
\hline $\mathbf{1}$ & 0,10 & 0,06 & 0,10 & 0,17 & 0,11 & 0,11 & $14,81 \%$ \\
\hline $\mathbf{6}$ & 0,11 & 0,13 & 0,15 & 0,15 & 0,12 & 0,13 & $5,38 \%$ \\
\hline $\mathbf{1 0}$ & 0,09 & 0,10 & 0,10 & 0,11 & 0,10 & 0,10 & $2,31 \%$ \\
\hline $\mathbf{1 4}$ & 0,14 & 0,16 & 0,15 & 0,13 & 0,21 & 0,16 & $14,91 \%$ \\
\hline $\mathbf{1 8}$ & 0,12 & 0,18 & 0,16 & 0,16 & 0,23 & 0,17 & $20,52 \%$ \\
\hline $\mathbf{1 9}$ & 0,14 & 0,13 & 0,16 & 0,12 & 0,10 & 0,13 & $-6,68 \%$ \\
\hline Média & $\mathbf{0 , 1 2}$ & $\mathbf{0 , 1 3}$ & $\mathbf{0 , 1 4}$ & $\mathbf{0 , 1 4}$ & $\mathbf{0 , 1 5}$ & $\mathbf{0 , 1 3}$ & $\mathbf{5 , 8 4 \%}$ \\
\hline
\end{tabular}




\begin{tabular}{|c|c|c|c|c|c|c|c|}
\hline \multicolumn{7}{|c|}{ GRUPO A - Imobilizado / Receita Líquida } \\
\hline Empresa & $\mathbf{2 0 0 5}$ & $\mathbf{2 0 0 6}$ & $\mathbf{2 0 0 7}$ & $\mathbf{2 0 0 8}$ & $\mathbf{2 0 0 9}$ & $\begin{array}{c}\text { Imobilizado } \\
\text { anual médio }\end{array}$ & $\begin{array}{c}\text { Cresc. anual } \\
\text { médio (\%) }\end{array}$ \\
\hline $\mathbf{1}$ & 0,20 & 0,15 & 0,17 & 0,20 & 0,15 & 0,17 & $-5,07 \%$ \\
\hline $\mathbf{6}$ & 0,68 & 0,64 & 0,60 & 0,32 & 0,24 & 0,50 & $-20,63 \%$ \\
\hline $\mathbf{1 0}$ & 0,17 & 0,14 & 0,13 & 0,12 & 0,12 & 0,14 & $-7,31 \%$ \\
\hline $\mathbf{1 4}$ & 0,47 & 0,46 & 0,43 & 0,36 & 0,36 & 0,41 & $-6,13 \%$ \\
\hline $\mathbf{1 8}$ & 0,59 & 0,73 & 0,59 & 0,52 & 0,73 & 0,63 & $7,86 \%$ \\
\hline $\mathbf{1 9}$ & 0,32 & 0,24 & 0,22 & 0,17 & 0,18 & 0,23 & $-13,06 \%$ \\
\hline Média & $\mathbf{0 , 4 0}$ & $\mathbf{0 , 3 9}$ & $\mathbf{0 , 3 6}$ & $\mathbf{0 , 2 8}$ & $\mathbf{0 , 3 0}$ & $\mathbf{0 , 3 5}$ & $\mathbf{- 7 , 0 2 \%}$ \\
\hline
\end{tabular}

\begin{tabular}{|c|c|c|c|c|c|c|c|}
\hline \multicolumn{7}{|c|}{ GRUPO A - Margem Operacional } \\
\hline Empresa & $\mathbf{2 0 0 5}$ & $\mathbf{2 0 0 6}$ & $\mathbf{2 0 0 7}$ & $\mathbf{2 0 0 8}$ & $\mathbf{2 0 0 9}$ & $\begin{array}{c}\text { MO anual } \\
\text { média }\end{array}$ & $\begin{array}{c}\text { Cresc. anual } \\
\text { médio } \\
(\mathbf{\%})\end{array}$ \\
\hline $\mathbf{1}$ & $12,72 \%$ & $20,74 \%$ & $11,79 \%$ & $11,10 \%$ & $12,39 \%$ & $13,75 \%$ & \\
\hline $\mathbf{6}$ & $18,66 \%$ & $12,33 \%$ & $17,52 \%$ & $16,76 \%$ & $25,79 \%$ & $18,21 \%$ & \\
\hline $\mathbf{1 0}$ & $12,15 \%$ & $14,03 \%$ & $14,76 \%$ & $17,92 \%$ & $10,26 \%$ & $13,83 \%$ & \\
\hline $\mathbf{1 4}$ & $23,19 \%$ & $10,40 \%$ & $7,67 \%$ & $12,66 \%$ & $11,62 \%$ & $13,11 \%$ & \\
\hline $\mathbf{1 8}$ & $18,51 \%$ & $5,69 \%$ & $4,70 \%$ & $16,37 \%$ & $10,36 \%$ & $11,13 \%$ & \\
\hline $\mathbf{1 9}$ & $15,68 \%$ & $10,38 \%$ & $13,17 \%$ & $14,52 \%$ & $-1,31 \%$ & $10,49 \%$ & \\
\hline Média & $16,82 \%$ & $12,26 \%$ & $11,60 \%$ & $14,89 \%$ & $11,52 \%$ & $13,42 \%$ & \\
\hline
\end{tabular}

\begin{tabular}{|c|c|c|c|c|c|c|c|}
\hline \multicolumn{7}{|c|}{ GRUPO A - Rentabilidade Operacional } \\
\hline Empresa & $\mathbf{2 0 0 5}$ & $\mathbf{2 0 0 6}$ & $\mathbf{2 0 0 7}$ & $\mathbf{2 0 0 8}$ & $\mathbf{2 0 0 9}$ & $\begin{array}{c}\text { MO anual } \\
\text { média }\end{array}$ & $\begin{array}{c}\text { Cresc. anual } \\
\text { médio (\%) }\end{array}$ \\
\hline $\mathbf{1}$ & $15,82 \%$ & $25,65 \%$ & $12,69 \%$ & $11,74 \%$ & $14,01 \%$ & $15,98 \%$ & \\
\hline $\mathbf{6}$ & $10,14 \%$ & $8,33 \%$ & $11,02 \%$ & $12,51 \%$ & $27,61 \%$ & $13,92 \%$ & \\
\hline $\mathbf{1 0}$ & $11,75 \%$ & $12,01 \%$ & $12,34 \%$ & $15,37 \%$ & $8,81 \%$ & $12,06 \%$ & \\
\hline $\mathbf{1 4}$ & $23,85 \%$ & $10,26 \%$ & $7,77 \%$ & $14,74 \%$ & $12,24 \%$ & $13,77 \%$ & \\
\hline $\mathbf{1 8}$ & $18,45 \%$ & $4,75 \%$ & $4,38 \%$ & $15,29 \%$ & $8,02 \%$ & $10,18 \%$ & \\
\hline $\mathbf{1 9}$ & $18,38 \%$ & $12,15 \%$ & $14,34 \%$ & $16,71 \%$ & $-1,38 \%$ & $12,04 \%$ & \\
\hline Média & $16,40 \%$ & $12,19 \%$ & $10,42 \%$ & $14,39 \%$ & $11,55 \%$ & $12,99 \%$ & \\
\hline
\end{tabular}


SETOR TÊXTIL - GRUPO B

\begin{tabular}{|c|c|c|c|c|c|c|c|}
\hline \multicolumn{7}{|c|}{ GRUPO B - Receita líquida (em milhares de R\$) } \\
\hline Empresa & $\mathbf{2 0 0 5}$ & $\mathbf{2 0 0 6}$ & $\mathbf{2 0 0 7}$ & $\mathbf{2 0 0 8}$ & $\mathbf{2 0 0 9}$ & $\begin{array}{c}\text { Rec. Liquida } \\
\text { anual média }\end{array}$ & $\begin{array}{c}\text { Cresc. anual } \\
\text { médio (\%) }\end{array}$ \\
\hline $\mathbf{4}$ & 136,31 & 134,95 & 146,36 & 214,54 & 222,92 & 171,02 & $14,49 \%$ \\
\hline $\mathbf{5}$ & 367,87 & 308,10 & 352,34 & 404,21 & 357,98 & 358,10 & $0,35 \%$ \\
\hline $\mathbf{7}$ & 205,12 & 242,63 & 277,12 & 324,25 & 379,92 & 285,80 & $16,67 \%$ \\
\hline $\mathbf{1 1}$ & 144,00 & 141,96 & 146,37 & 155,14 & 171,17 & 151,73 & $4,50 \%$ \\
\hline $\mathbf{1 2}$ & 302,15 & 297,49 & 269,47 & 318,59 & 311,25 & 299,79 & $1,24 \%$ \\
\hline $\mathbf{1 3}$ & 86,84 & 131,73 & 139,83 & 133,34 & 125,57 & 123,46 & $11,84 \%$ \\
\hline Média & $\mathbf{2 0 7 , 0 5}$ & $\mathbf{2 0 9 , 4 8}$ & $\mathbf{2 2 1 , 9 1}$ & $\mathbf{2 5 8 , 3 4}$ & $\mathbf{2 6 1 , 4 7}$ & $\mathbf{2 3 1 , 6 5}$ & $\mathbf{6 , 1 8 \%}$ \\
\hline
\end{tabular}

\begin{tabular}{|c|c|c|c|c|c|c|c|}
\hline \multicolumn{9}{|c|}{ GRUPO B - CDT / REC } \\
\hline Empresa & $\mathbf{2 0 0 5}$ & $\mathbf{2 0 0 6}$ & $\mathbf{2 0 0 7}$ & $\mathbf{2 0 0 8}$ & $\mathbf{2 0 0 9}$ & $\begin{array}{c}\text { CDT anual } \\
\text { média }\end{array}$ & $\begin{array}{c}\text { Cresc. anual } \\
\text { médio (\%) }\end{array}$ \\
\hline $\mathbf{4}$ & 0,92 & 0,99 & 0,96 & 0,93 & 1,16 & 0,99 & $6,34 \%$ \\
\hline $\mathbf{5}$ & 0,89 & 1,10 & 0,99 & 0,93 & 0,93 & 0,97 & $1,82 \%$ \\
\hline $\mathbf{7}$ & 0,93 & 1,00 & 0,91 & 1,01 & 0,87 & 0,94 & $-1,07 \%$ \\
\hline $\mathbf{1 1}$ & 0,90 & 0,88 & 0,90 & 0,92 & 0,97 & 0,91 & $1,78 \%$ \\
\hline $\mathbf{1 2}$ & 0,93 & 1,03 & 0,90 & 0,95 & 0,93 & 0,95 & $0,57 \%$ \\
\hline $\mathbf{1 3}$ & 0,99 & 0,88 & 0,92 & 0,97 & 0,97 & 0,95 & $-0,32 \%$ \\
\hline Média & $\mathbf{0 , 9 3}$ & $\mathbf{0 , 9 8}$ & $\mathbf{0 , 9 3}$ & $\mathbf{0 , 9 5}$ & $\mathbf{0 , 9 7}$ & $\mathbf{0 , 9 5}$ & $\mathbf{1 , 2 2 \%}$ \\
\hline
\end{tabular}

\begin{tabular}{|c|c|c|c|c|c|c|c|}
\hline \multicolumn{7}{|c|}{ GRUPO B - Estoque / Receita Líquida } \\
\hline Empresa & $\mathbf{2 0 0 5}$ & $\mathbf{2 0 0 6}$ & $\mathbf{2 0 0 7}$ & $\mathbf{2 0 0 8}$ & $\mathbf{2 0 0 9}$ & $\begin{array}{c}\text { Estoque/RL } \\
\text { média }\end{array}$ & $\begin{array}{c}\text { Cresc. anual } \\
\text { médio (\%) }\end{array}$ \\
\hline $\mathbf{4}$ & 0,16 & 0,16 & 0,19 & 0,24 & 0,17 & 0,18 & $4,74 \%$ \\
\hline $\mathbf{5}$ & 0,21 & 0,25 & 0,19 & 0,20 & 0,18 & 0,20 & $-3,04 \%$ \\
\hline $\mathbf{7}$ & 0,08 & 0,11 & 0,10 & 0,14 & 0,09 & 0,10 & $9,65 \%$ \\
\hline $\mathbf{1 1}$ & 0,17 & 0,18 & 0,20 & 0,26 & 0,25 & 0,21 & $10,82 \%$ \\
\hline $\mathbf{1 2}$ & 0,26 & 0,17 & 0,14 & 0,23 & 0,20 & 0,20 & $-0,53 \%$ \\
\hline $\mathbf{1 3}$ & 0,48 & 0,37 & 0,39 & 0,31 & 0,38 & 0,39 & $-4,29 \%$ \\
\hline Média & $\mathbf{0 , 2 3}$ & $\mathbf{0 , 2 1}$ & $\mathbf{0 , 2 0}$ & $\mathbf{0 , 2 3}$ & $\mathbf{0 , 2 1}$ & $\mathbf{0 , 2 1}$ & $\mathbf{- 1 , 3 7 \%}$ \\
\hline
\end{tabular}




\begin{tabular}{|c|c|c|c|c|c|c|c|}
\hline \multicolumn{7}{|c|}{ GRUPO B - Imobilizado / Receita Líquida } \\
\hline Empresa & $\mathbf{2 0 0 5}$ & $\mathbf{2 0 0 6}$ & $\mathbf{2 0 0 7}$ & $\mathbf{2 0 0 8}$ & $\mathbf{2 0 0 9}$ & $\begin{array}{c}\text { CDT anual } \\
\text { média }\end{array}$ & $\begin{array}{c}\text { Cresc. anual } \\
\text { médio }(\mathbf{\%})\end{array}$ \\
\hline $\mathbf{4}$ & 0,29 & 0,33 & 0,33 & 0,22 & 0,17 & 0,27 & $-11,25 \%$ \\
\hline $\mathbf{5}$ & 0,55 & 0,65 & 0,54 & 0,43 & 0,47 & 0,52 & $-2,34 \%$ \\
\hline $\mathbf{7}$ & 0,21 & 0,15 & 0,14 & 0,14 & 0,12 & 0,15 & $-11,55 \%$ \\
\hline $\mathbf{1 1}$ & 0,37 & 0,47 & 0,50 & 0,47 & 0,42 & 0,44 & $4,64 \%$ \\
\hline $\mathbf{1 2}$ & 0,22 & 0,20 & 0,20 & 0,21 & 0,21 & 0,21 & $-0,48 \%$ \\
\hline $\mathbf{1 3}$ & 0,64 & 0,41 & 0,46 & 1,07 & 0,97 & 0,71 & $25,19 \%$ \\
\hline Média & $\mathbf{0 , 3 8}$ & $\mathbf{0 , 3 7}$ & $\mathbf{0 , 3 6}$ & $\mathbf{0 , 4 2}$ & $\mathbf{0 , 3 9}$ & $\mathbf{0 , 3 8}$ & $\mathbf{1 , 4 5 \%}$ \\
\hline
\end{tabular}

\begin{tabular}{|c|c|c|c|c|c|c|c|}
\hline \multicolumn{7}{|c|}{ GRUPO B - Margem Operacional } \\
\hline \multirow{2}{*}{ Empresa } & $\mathbf{2 0 0 5}$ & $\mathbf{2 0 0 6}$ & $\mathbf{2 0 0 7}$ & $\mathbf{2 0 0 8}$ & $\mathbf{2 0 0 9}$ & $\begin{array}{c}\text { Rec. Liquida } \\
\text { anual média }\end{array}$ & $\begin{array}{c}\text { Cresc. anual } \\
\text { médio } \\
(\boldsymbol{\%})\end{array}$ \\
\hline $\mathbf{4}$ & $7,65 \%$ & $1,21 \%$ & $3,80 \%$ & $7,36 \%$ & $-15,51 \%$ & $0,90 \%$ & \\
\hline $\mathbf{5}$ & $10,95 \%$ & $-9,98 \%$ & $1,23 \%$ & $6,73 \%$ & $7,18 \%$ & $3,22 \%$ & \\
\hline $\mathbf{7}$ & $6,97 \%$ & $-0,08 \%$ & $9,25 \%$ & $-0,56 \%$ & $12,87 \%$ & $5,69 \%$ & \\
\hline $\mathbf{1 1}$ & $9,79 \%$ & $12,09 \%$ & $10,27 \%$ & $8,22 \%$ & $3,35 \%$ & $8,75 \%$ & \\
\hline $\mathbf{1 2}$ & $7,26 \%$ & $-3,30 \%$ & $10,23 \%$ & $4,81 \%$ & $6,76 \%$ & $5,15 \%$ & \\
\hline $\mathbf{1 3}$ & $0,56 \%$ & $11,75 \%$ & $8,42 \%$ & $3,04 \%$ & $2,72 \%$ & $5,30 \%$ & \\
\hline Média & $7,20 \%$ & $1,95 \%$ & $7,20 \%$ & $4,93 \%$ & $2,90 \%$ & $4,84 \%$ & \\
\hline
\end{tabular}

\begin{tabular}{|c|c|c|c|c|c|c|c|}
\hline \multicolumn{7}{|c|}{ GRUPO B - Rentabilidade Operacional } \\
\hline \multirow{2}{*}{ Empresa } & $\mathbf{2 0 0 5}$ & $\mathbf{2 0 0 6}$ & $\mathbf{2 0 0 7}$ & $\mathbf{2 0 0 8}$ & $\mathbf{2 0 0 9}$ & $\begin{array}{c}\text { Rec. Liquida } \\
\text { anual média }\end{array}$ & $\begin{array}{c}\text { Cresc. anual } \\
\text { médio }\end{array}$ \\
\hline $\mathbf{4}$ & $9,95 \%$ & $1,36 \%$ & $4,20 \%$ & $10,39 \%$ & $-20,78 \%$ & $1,03 \%$ & \\
\hline $\mathbf{5}$ & $10,95 \%$ & $-7,92 \%$ & $1,15 \%$ & $7,57 \%$ & $7,30 \%$ & $3,81 \%$ & \\
\hline $\mathbf{7}$ & $12,71 \%$ & $-0,09 \%$ & $8,46 \%$ & $-0,48 \%$ & $13,21 \%$ & $6,76 \%$ & \\
\hline $\mathbf{1 1}$ & $8,62 \%$ & $8,77 \%$ & $6,52 \%$ & $5,68 \%$ & $2,71 \%$ & $6,46 \%$ & \\
\hline $\mathbf{1 2}$ & $8,53 \%$ & $-4,21 \%$ & $13,08 \%$ & $5,81 \%$ & $7,03 \%$ & $6,05 \%$ & \\
\hline $\mathbf{1 3}$ & $0,32 \%$ & $9,92 \%$ & $6,57 \%$ & $1,78 \%$ & $1,34 \%$ & $3,99 \%$ & \\
\hline Média & $8,51 \%$ & $1,31 \%$ & $6,66 \%$ & $5,13 \%$ & $1,80 \%$ & $4,68 \%$ & \\
\hline
\end{tabular}


SETOR TÊXTIL - GRUPO C

\begin{tabular}{|c|c|c|c|c|c|c|c|}
\hline \multicolumn{7}{|c|}{ GRUPO C - Receita líquida (em milhares de R\$) } \\
\hline Empresa & $\mathbf{2 0 0 5}$ & $\mathbf{2 0 0 6}$ & $\mathbf{2 0 0 7}$ & $\mathbf{2 0 0 8}$ & $\mathbf{2 0 0 9}$ & $\begin{array}{c}\text { Rec. Liquida } \\
\text { anual média }\end{array}$ & $\begin{array}{c}\text { Cresc. anual } \\
\text { médio (\%) }\end{array}$ \\
\hline $\mathbf{2}$ & 68,78 & 53,30 & 32,38 & 16,64 & 12,82 & 36,78 & $-33,34 \%$ \\
\hline $\mathbf{3}$ & 160,34 & 139,45 & 133,26 & 141,52 & 128,86 & 140,69 & $-5,05 \%$ \\
\hline $\mathbf{8}$ & 205,22 & 190,99 & 190,77 & 196,08 & 204,99 & 197,61 & $0,07 \%$ \\
\hline $\mathbf{9}$ & 65,12 & 60,62 & 65,49 & 78,88 & 56,84 & 65,39 & $-1,59 \%$ \\
\hline $\mathbf{1 5}$ & 34,03 & 32,23 & 31,85 & 45,40 & 45,42 & 37,79 & $9,03 \%$ \\
\hline $\mathbf{1 6}$ & 56,80 & 56,15 & 33,54 & 17,62 & 6,83 & 34,19 & $-37,53 \%$ \\
\hline $\mathbf{1 7}$ & 262,04 & 291,04 & 300,46 & 305,48 & 279,72 & 287,75 & $1,89 \%$ \\
\hline Média & $\mathbf{1 2 1 , 7 6}$ & $\mathbf{1 1 7 , 6 8}$ & $\mathbf{1 1 2 , 5 3}$ & $\mathbf{1 1 4 , 5 2}$ & $\mathbf{1 0 5 , 0 7}$ & $\mathbf{1 1 4 , 3 1}$ & $\mathbf{- 3 , 5 5 \%}$ \\
\hline
\end{tabular}

\begin{tabular}{|c|c|c|c|c|c|c|c|}
\hline \multicolumn{9}{|c|}{ GRUPO C - CDT / REC } \\
\hline Empresa & $\mathbf{2 0 0 5}$ & $\mathbf{2 0 0 6}$ & $\mathbf{2 0 0 7}$ & $\mathbf{2 0 0 8}$ & $\mathbf{2 0 0 9}$ & $\begin{array}{c}\text { CDT anual } \\
\text { média }\end{array}$ & $\begin{array}{c}\text { Cresc. anual } \\
\text { médio (\%) }\end{array}$ \\
\hline $\mathbf{2}$ & 0,96 & 0,97 & 1,18 & 1,64 & 3,11 & 1,57 & $37,80 \%$ \\
\hline $\mathbf{3}$ & 1,00 & 1,01 & 0,98 & 1,00 & 1,38 & 1,07 & $9,39 \%$ \\
\hline $\mathbf{8}$ & 1,12 & 1,03 & 1,05 & 1,01 & 1,04 & 1,05 & $-1,66 \%$ \\
\hline $\mathbf{9}$ & 1,16 & 1,09 & 1,10 & 0,99 & 1,17 & 1,10 & $0,86 \%$ \\
\hline $\mathbf{1 5}$ & 1,19 & 1,22 & 1,19 & 1,12 & 2,61 & 1,47 & $31,75 \%$ \\
\hline $\mathbf{1 6}$ & 1,07 & 1,00 & 1,16 & 1,56 & 1,62 & 1,28 & $12,00 \%$ \\
\hline $\mathbf{1 7}$ & 1,15 & 1,16 & 1,10 & 1,15 & 1,23 & 1,16 & $1,78 \%$ \\
\hline Média & $\mathbf{1 , 0 9}$ & $\mathbf{1 , 0 7}$ & $\mathbf{1 , 1 1}$ & $\mathbf{1 , 2 1}$ & $\mathbf{1 , 7 4}$ & $\mathbf{1 , 2 4}$ & $\mathbf{1 3 , 5 7 \%}$ \\
\hline
\end{tabular}

\begin{tabular}{|c|c|c|c|c|c|c|c|}
\hline \multicolumn{7}{|c|}{ GRUPO C - Estoque / Receita Líquida } \\
\hline Empresa & $\mathbf{2 0 0 5}$ & $\mathbf{2 0 0 6}$ & $\mathbf{2 0 0 7}$ & $\mathbf{2 0 0 8}$ & $\mathbf{2 0 0 9}$ & $\begin{array}{c}\text { Estoque } \\
\text { anual médio }\end{array}$ & $\begin{array}{c}\text { Cresc. anual } \\
\text { médio (\%) }\end{array}$ \\
\hline $\mathbf{2}$ & 0,09 & 0,19 & 0,28 & 0,27 & 0,17 & 0,20 & $29,59 \%$ \\
\hline $\mathbf{3}$ & 0,14 & 0,12 & 0,16 & 0,13 & 0,17 & 0,14 & $7,30 \%$ \\
\hline $\mathbf{8}$ & 0,35 & 0,38 & 0,36 & 0,39 & 0,35 & 0,37 & $0,02 \%$ \\
\hline $\mathbf{9}$ & 0,26 & 0,34 & 0,29 & 0,24 & 0,23 & 0,27 & $-1,67 \%$ \\
\hline $\mathbf{1 5}$ & 0,16 & 0,24 & 0,16 & 0,16 & 0,12 & 0,17 & $-3,08 \%$ \\
\hline $\mathbf{1 6}$ & 0,18 & 0,12 & 0,12 & 0,23 & 0,02 & 0,14 & $-7,48 \%$ \\
\hline $\mathbf{1 7}$ & 0,13 & 0,13 & 0,16 & 0,10 & 0,11 & 0,13 & $0,37 \%$ \\
\hline Média & $\mathbf{0 , 1 9}$ & $\mathbf{0 , 2 2}$ & $\mathbf{0 , 2 2}$ & $\mathbf{0 , 2 2}$ & $\mathbf{0 , 1 7}$ & $\mathbf{0 , 2 0}$ & $\mathbf{- 1 , 8 8 \%}$ \\
\hline
\end{tabular}




\begin{tabular}{|c|c|c|c|c|c|c|c|}
\hline \multicolumn{7}{|c|}{ GRUPO C - Imobilizado / Receita Líquida } \\
\hline Empresa & $\mathbf{2 0 0 5}$ & $\mathbf{2 0 0 6}$ & $\mathbf{2 0 0 7}$ & $\mathbf{2 0 0 8}$ & $\mathbf{2 0 0 9}$ & $\begin{array}{c}\text { CDT anual } \\
\text { média }\end{array}$ & $\begin{array}{c}\text { Cresc. anual } \\
\text { médio }(\mathbf{\%})\end{array}$ \\
\hline $\mathbf{2}$ & 0,25 & 0,78 & 1,25 & 2,36 & 2,50 & 1,43 & $92,44 \%$ \\
\hline $\mathbf{3}$ & 0,20 & 0,21 & 0,19 & 0,17 & 0,17 & 0,19 & $-4,21 \%$ \\
\hline $\mathbf{8}$ & 0,31 & 0,27 & 0,22 & 0,18 & 0,20 & 0,24 & $-9,10 \%$ \\
\hline $\mathbf{9}$ & 1,40 & 1,40 & 1,22 & 0,96 & 1,23 & 1,24 & $-1,28 \%$ \\
\hline $\mathbf{1 5}$ & 1,20 & 1,17 & 1,09 & 0,24 & 0,25 & 0,79 & $-21,11 \%$ \\
\hline $\mathbf{1 6}$ & 0,97 & 0,90 & 1,37 & 1,66 & 4,13 & 1,81 & $53,71 \%$ \\
\hline $\mathbf{1 7}$ & 1,19 & 0,97 & 0,89 & 0,82 & 0,81 & 0,94 & $-8,94 \%$ \\
\hline Média & $\mathbf{0 , 7 9}$ & $\mathbf{0 , 8 2}$ & $\mathbf{0 , 8 9}$ & $\mathbf{0 , 9 1}$ & $\mathbf{1 , 3 3}$ & $\mathbf{0 , 9 5}$ & $\mathbf{1 5 , 1 8 \%}$ \\
\hline
\end{tabular}

\begin{tabular}{|c|c|c|c|c|c|c|c|}
\hline \multicolumn{9}{|c|}{ ERUPO C - Margem Operacional } \\
\hline $\mathbf{2}$ & $\mathbf{2 0 0 5}$ & $\mathbf{2 0 0 6}$ & $\mathbf{2 0 0 7}$ & $\mathbf{2 0 0 8}$ & $\mathbf{2 0 0 9}$ & $\begin{array}{c}\text { Rec. Liquida } \\
\text { anual média }\end{array}$ & $\begin{array}{c}\text { Cresc. anual } \\
\text { médio } \\
(\mathbf{\%})\end{array}$ \\
\hline $\mathbf{3}$ & $3,64 \%$ & $2,87 \%$ & $-18,40 \%$ & $-63,57 \%$ & $-211,36 \%$ & $-57,36 \%$ & \\
\hline $\mathbf{8}$ & $-0,21 \%$ & $-1,27 \%$ & $2,07 \%$ & $0,29 \%$ & $-37,58 \%$ & $-7,34 \%$ & \\
\hline $\mathbf{9}$ & $-11,96 \%$ & $-2,86 \%$ & $-4,73 \%$ & $-1,14 \%$ & $-4,27 \%$ & $-4,99 \%$ & \\
\hline $\mathbf{1 5}$ & $-15,92 \%$ & $-9,36 \%$ & $-9,78 \%$ & $0,76 \%$ & $-17,43 \%$ & $-10,35 \%$ & \\
\hline $\mathbf{1 6}$ & $-6,71 \%$ & $-21,61 \%$ & $-19,39 \%$ & $-12,20 \%$ & $-161,31 \%$ & $-46,76 \%$ & \\
\hline $\mathbf{1 7}$ & $-15,42 \%$ & $-15,60 \%$ & $-10,46 \%$ & $-14,79 \%$ & $-23,41 \%$ & $-15,94 \%$ & \\
\hline Média & $-9,41 \%$ & $-6,77 \%$ & $-10,95 \%$ & $-20,94 \%$ & $-73,87 \%$ & $-24,39 \%$ & \\
\hline
\end{tabular}

\begin{tabular}{|c|c|c|c|c|c|c|c|}
\hline \multicolumn{7}{|c|}{ GRUPO C - Rentabilidade Operacional } \\
\hline \multirow{2}{*}{ Empresa } & $\mathbf{2 0 0 5}$ & $\mathbf{2 0 0 6}$ & $\mathbf{2 0 0 7}$ & $\mathbf{2 0 0 8}$ & $\mathbf{2 0 0 9}$ & $\begin{array}{c}\text { Rec. Liquida } \\
\text { anual média }\end{array}$ & $\begin{array}{c}\text { Cresc. anual } \\
\text { médio }(\boldsymbol{\%})\end{array}$ \\
\hline $\mathbf{2}$ & $5,34 \%$ & $2,51 \%$ & $-8,20 \%$ & $-16,05 \%$ & $-49,08 \%$ & $-13,10 \%$ & \\
\hline $\mathbf{3}$ & $-0,23 \%$ & $-1,16 \%$ & $1,84 \%$ & $0,26 \%$ & $-26,67 \%$ & $-5,19 \%$ & \\
\hline $\mathbf{8}$ & $-8,37 \%$ & $-1,88 \%$ & $-3,04 \%$ & $-0,73 \%$ & $-2,88 \%$ & $-3,38 \%$ & \\
\hline $\mathbf{9}$ & $-7,27 \%$ & $-4,03 \%$ & $-4,82 \%$ & $0,47 \%$ & $-8,23 \%$ & $-4,78 \%$ & \\
\hline $\mathbf{1 5}$ & $-11,76 \%$ & $-13,32 \%$ & $-12,72 \%$ & $-16,59 \%$ & $-308,72 \%$ & $-72,62 \%$ & \\
\hline $\mathbf{1 6}$ & $-4,72 \%$ & $0,33 \%$ & $-7,90 \%$ & $-18,65 \%$ & $-10,87 \%$ & $-8,36 \%$ & \\
\hline $\mathbf{1 7}$ & $-7,14 \%$ & $-8,30 \%$ & $-5,96 \%$ & $-9,40 \%$ & $-15,39 \%$ & $-9,24 \%$ & \\
\hline Média & $-4,88 \%$ & $-3,69 \%$ & $-5,83 \%$ & $-8,67 \%$ & $-60,26 \%$ & $-16,67 \%$ & \\
\hline
\end{tabular}




\section{APÊNDICE 6 - INDICADORES DO SETOR SIDERURGIA/METALURGIA}

\section{SETOR SIDERURGIA/METALURGIA - GRUPO A}

\begin{tabular}{|c|c|c|c|c|c|c|c|}
\hline \multicolumn{7}{|c|}{ GRUPO A - Receita líquida (em milhares de R\$) } \\
\hline Empresa & $\mathbf{2 0 0 5}$ & $\mathbf{2 0 0 6}$ & $\mathbf{2 0 0 7}$ & $\mathbf{2 0 0 8}$ & $\mathbf{2 0 0 9}$ & $\begin{array}{c}\text { Rec. Liquida } \\
\text { anual média }\end{array}$ & $\begin{array}{c}\text { Cresc. anual } \\
\text { médio }(\mathbf{\%})\end{array}$ \\
\hline $\mathbf{1}$ & 153,02 & 158,70 & 167,72 & 198,16 & 123,10 & 160,14 & $-2,58 \%$ \\
\hline $\mathbf{3}$ & $1.783,11$ & $1.030,77$ & $1.808,78$ & $2.270,22$ & $2.127,47$ & $1.804,07$ & $13,13 \%$ \\
\hline $\mathbf{4}$ & 427,25 & 398,08 & 446,65 & 878,91 & 450,75 & 520,33 & $13,36 \%$ \\
\hline $\mathbf{6}$ & 318,43 & 408,87 & 429,27 & 599,22 & 679,39 & 487,04 & $21,59 \%$ \\
\hline $\mathbf{1 1}$ & 154,21 & 156,77 & 189,07 & 243,45 & 187,70 & 186,24 & $7,03 \%$ \\
\hline $\mathbf{1 4}$ & 131,36 & 143,24 & 147,70 & 152,52 & 122,69 & 139,50 & $-1,03 \%$ \\
\hline Média & $\mathbf{4 9 4 , 5 6}$ & $\mathbf{3 8 2 , 7 4}$ & $\mathbf{5 3 1 , 5 3}$ & $\mathbf{7 2 3 , 7 4}$ & $\mathbf{6 1 5 , 1 8}$ & $\mathbf{5 4 9 , 5 5}$ & $\mathbf{9 , 3 6 \%}$ \\
\hline
\end{tabular}

\begin{tabular}{|c|c|c|c|c|c|c|c|}
\hline \multicolumn{9}{|c|}{ GRUPO A - CDT / REC } \\
\hline Empresa & $\mathbf{2 0 0 5}$ & $\mathbf{2 0 0 6}$ & $\mathbf{2 0 0 7}$ & $\mathbf{2 0 0 8}$ & $\mathbf{2 0 0 9}$ & $\begin{array}{c}\text { CDT anual } \\
\text { média }\end{array}$ & $\begin{array}{c}\text { Cresc. anual } \\
\text { médio (\%) }\end{array}$ \\
\hline $\mathbf{1}$ & 0,85 & 0,81 & 0,87 & 0,86 & 0,87 & 0,85 & $0,73 \%$ \\
\hline $\mathbf{3}$ & 0,73 & 0,86 & 0,80 & 0,76 & 0,78 & 0,78 & $2,37 \%$ \\
\hline $\mathbf{4}$ & 0,82 & 0,91 & 0,86 & 0,54 & 0,96 & 0,82 & $11,66 \%$ \\
\hline $\mathbf{6}$ & 0,88 & 0,84 & 0,79 & 0,81 & 0,71 & 0,80 & $-5,01 \%$ \\
\hline $\mathbf{1 1}$ & 0,90 & 0,88 & 0,86 & 0,78 & 0,82 & 0,85 & $-2,15 \%$ \\
\hline $\mathbf{1 4}$ & 0,87 & 0,82 & 0,85 & 0,86 & 0,88 & 0,85 & $0,55 \%$ \\
\hline Média & $\mathbf{0 , 8 4}$ & $\mathbf{0 , 8 5}$ & $\mathbf{0 , 8 4}$ & $\mathbf{0 , 7 7}$ & $\mathbf{0 , 8 4}$ & $\mathbf{0 , 8 3}$ & $\mathbf{0 , 1 8 \%}$ \\
\hline
\end{tabular}

\begin{tabular}{|c|c|c|c|c|c|c|c|}
\hline \multicolumn{7}{|c|}{ GRUPO A - Estoque / REC } \\
\hline Empresa & $\mathbf{2 0 0 5}$ & $\mathbf{2 0 0 6}$ & $\mathbf{2 0 0 7}$ & $\mathbf{2 0 0 8}$ & $\mathbf{2 0 0 9}$ & $\begin{array}{c}\text { Estoque/REC } \\
\text { média }\end{array}$ & $\begin{array}{c}\text { Cresc. anual } \\
\text { médio (\%) }\end{array}$ \\
\hline $\mathbf{1}$ & 0,06 & 0,07 & 0,08 & 0,10 & 0,11 & 0,08 & $18,47 \%$ \\
\hline $\mathbf{3}$ & 0,15 & 0,54 & 0,27 & 0,27 & 0,09 & 0,26 & $37,19 \%$ \\
\hline $\mathbf{4}$ & 0,37 & 0,31 & 0,31 & 0,26 & 0,34 & 0,32 & $-0,43 \%$ \\
\hline $\mathbf{6}$ & 0,37 & 0,26 & 0,41 & 0,42 & 0,31 & 0,35 & $1,06 \%$ \\
\hline $\mathbf{1 1}$ & 0,11 & 0,13 & 0,11 & 0,15 & 0,17 & 0,13 & $11,34 \%$ \\
\hline $\mathbf{1 4}$ & 0,23 & 0,20 & 0,20 & 0,26 & 0,18 & 0,21 & $-3,93 \%$ \\
\hline Média & $\mathbf{0 , 2 1}$ & $\mathbf{0 , 2 5}$ & $\mathbf{0 , 2 3}$ & $\mathbf{0 , 2 4}$ & $\mathbf{0 , 2 0}$ & $\mathbf{0 , 2 3}$ & $\mathbf{- 0 , 9 2 \%}$ \\
\hline
\end{tabular}




\begin{tabular}{|c|c|c|c|c|c|c|c|}
\hline \multicolumn{9}{|c|}{ GRUPO A - Imobilizado / REC } \\
\hline Empresa & $\mathbf{2 0 0 5}$ & $\mathbf{2 0 0 6}$ & $\mathbf{2 0 0 7}$ & $\mathbf{2 0 0 8}$ & $\mathbf{2 0 0 9}$ & $\begin{array}{c}\text { Imobilizado/REC } \\
\text { anual médio }\end{array}$ & $\begin{array}{c}\text { Cresc. anual } \\
\text { médio (\%) }\end{array}$ \\
\hline $\mathbf{1}$ & 0,29 & 0,31 & 0,31 & 0,27 & 0,41 & 0,32 & $11,62 \%$ \\
\hline $\mathbf{3}$ & 0,15 & 0,26 & 0,13 & 0,10 & 0,11 & 0,15 & $3,71 \%$ \\
\hline $\mathbf{4}$ & 0,49 & 0,55 & 0,53 & 0,34 & 0,73 & 0,53 & $22,38 \%$ \\
\hline $\mathbf{6}$ & 0,28 & 0,27 & 0,28 & 0,27 & 0,26 & 0,27 & $-0,98 \%$ \\
\hline $\mathbf{1 1}$ & 0,13 & 0,13 & 0,13 & 0,15 & 0,21 & 0,15 & $13,25 \%$ \\
\hline $\mathbf{1 4}$ & 0,14 & 0,12 & 0,12 & 0,13 & 0,15 & 0,13 & $1,19 \%$ \\
\hline Média & $\mathbf{0 , 2 5}$ & $\mathbf{0 , 2 7}$ & $\mathbf{0 , 2 5}$ & $\mathbf{0 , 2 1}$ & $\mathbf{0 , 3 1}$ & $\mathbf{0 , 2 6}$ & $\mathbf{8 , 9 6 \%}$ \\
\hline
\end{tabular}

\begin{tabular}{|c|c|c|c|c|c|c|c|}
\hline \multicolumn{9}{|c|}{ GRUPO A - Margem Operacional } \\
\hline Empresa & $\mathbf{2 0 0 5}$ & $\mathbf{2 0 0 6}$ & $\mathbf{2 0 0 7}$ & $\mathbf{2 0 0 8}$ & $\mathbf{2 0 0 9}$ & $\begin{array}{c}\text { MO anual } \\
\text { média }\end{array}$ & $\begin{array}{c}\text { Cresc. anual } \\
\text { médio (\%) }\end{array}$ \\
\hline $\mathbf{1}$ & $14,98 \%$ & $18,71 \%$ & $12,98 \%$ & $14,17 \%$ & $12,77 \%$ & $14,72 \%$ & \\
\hline $\mathbf{3}$ & $27,35 \%$ & $14,28 \%$ & $19,83 \%$ & $24,50 \%$ & $21,65 \%$ & $21,52 \%$ & \\
\hline $\mathbf{4}$ & $18,32 \%$ & $9,47 \%$ & $13,61 \%$ & $45,93 \%$ & $3,86 \%$ & $18,24 \%$ & \\
\hline $\mathbf{6}$ & $12,26 \%$ & $15,68 \%$ & $21,09 \%$ & $19,50 \%$ & $28,97 \%$ & $19,50 \%$ & \\
\hline $\mathbf{1 1}$ & $9,67 \%$ & $12,10 \%$ & $14,41 \%$ & $22,43 \%$ & $17,69 \%$ & $15,26 \%$ & \\
\hline $\mathbf{1 4}$ & $13,37 \%$ & $18,00 \%$ & $15,13 \%$ & $14,43 \%$ & $11,68 \%$ & $14,52 \%$ & \\
\hline Média & $15,99 \%$ & $14,71 \%$ & $16,18 \%$ & $23,49 \%$ & $16,10 \%$ & $17,29 \%$ & \\
\hline
\end{tabular}

\begin{tabular}{|c|c|c|c|c|c|c|c|}
\hline \multicolumn{7}{|c|}{ GRUPO A - Rentabilidade Operacional } \\
\hline Empresa & $\mathbf{2 0 0 5}$ & $\mathbf{2 0 0 6}$ & $\mathbf{2 0 0 7}$ & $\mathbf{2 0 0 8}$ & $\mathbf{2 0 0 9}$ & $\begin{array}{c}\text { RO anual } \\
\text { média }\end{array}$ & $\begin{array}{c}\text { Cresc. anual } \\
\text { médio (\%) }\end{array}$ \\
\hline $\mathbf{1}$ & $31,77 \%$ & $34,18 \%$ & $19,96 \%$ & $18,57 \%$ & $9,72 \%$ & $22,84 \%$ & \\
\hline $\mathbf{3}$ & $41,69 \%$ & $11,02 \%$ & $22,01 \%$ & $29,19 \%$ & $24,01 \%$ & $25,59 \%$ & \\
\hline $\mathbf{4}$ & $14,31 \%$ & $6,69 \%$ & $9,94 \%$ & $49,27 \%$ & $1,77 \%$ & $16,39 \%$ & \\
\hline $\mathbf{6}$ & $9,90 \%$ & $13,75 \%$ & $16,53 \%$ & $16,67 \%$ & $23,44 \%$ & $16,06 \%$ & \\
\hline $\mathbf{1 1}$ & $19,38 \%$ & $22,18 \%$ & $26,03 \%$ & $39,38 \%$ & $19,97 \%$ & $25,39 \%$ & \\
\hline $\mathbf{1 4}$ & $13,30 \%$ & $17,58 \%$ & $13,04 \%$ & $11,04 \%$ & $6,78 \%$ & $12,35 \%$ & \\
\hline Média & $21,72 \%$ & $17,57 \%$ & $17,92 \%$ & $27,35 \%$ & $14,28 \%$ & $19,77 \%$ & \\
\hline
\end{tabular}


SETOR SIDERURGIA/METALURGIA - GRUPO B

\begin{tabular}{|c|c|c|c|c|c|c|c|}
\hline \multicolumn{7}{|c|}{ GRUPO B - Receita líquida (em milhares de R\$) } \\
\hline Empresa & $\mathbf{2 0 0 5}$ & $\mathbf{2 0 0 6}$ & $\mathbf{2 0 0 7}$ & $\mathbf{2 0 0 8}$ & $\mathbf{2 0 0 9}$ & $\begin{array}{c}\text { Rec. Liquida } \\
\text { anual média }\end{array}$ & $\begin{array}{c}\text { Cresc. anual } \\
\text { médio (\%) }\end{array}$ \\
\hline $\mathbf{5}$ & 94,06 & 99,15 & 111,60 & 118,92 & 120,81 & 108,91 & $6,53 \%$ \\
\hline $\mathbf{7}$ & 17,65 & 18,85 & 24,79 & 30,24 & 30,06 & 24,32 & $14,92 \%$ \\
\hline $\mathbf{9}$ & 92,25 & 90,17 & 99,24 & 99,87 & 92,25 & 94,75 & $0,20 \%$ \\
\hline $\mathbf{1 2}$ & 240,28 & 221,65 & 262,71 & 357,33 & 295,53 & 275,50 & $7,37 \%$ \\
\hline Média & $\mathbf{1 1 1 , 0 6}$ & $\mathbf{1 0 7 , 4 6}$ & $\mathbf{1 2 4 , 5 8}$ & $\mathbf{1 5 1 , 5 9}$ & $\mathbf{1 3 4 , 6 6}$ & $\mathbf{1 2 5 , 8 7}$ & $\mathbf{5 , 8 0 \%}$ \\
\hline
\end{tabular}

\begin{tabular}{|c|c|c|c|c|c|c|c|}
\hline \multicolumn{7}{|c|}{ GRUPO B - CDT / REC } \\
\hline Empresa & $\mathbf{2 0 0 5}$ & $\mathbf{2 0 0 6}$ & $\mathbf{2 0 0 7}$ & $\mathbf{2 0 0 8}$ & $\mathbf{2 0 0 9}$ & $\begin{array}{c}\text { CDT anual } \\
\text { média }\end{array}$ & $\begin{array}{c}\text { Cresc. anual } \\
\text { médio (\%) }\end{array}$ \\
\hline $\mathbf{5}$ & 0,88 & 0,86 & 0,85 & 0,90 & 0,93 & 0,88 & $1,51 \%$ \\
\hline $\mathbf{7}$ & 0,98 & 1,02 & 0,87 & 1,00 & 0,91 & 0,96 & $-1,09 \%$ \\
\hline $\mathbf{9}$ & 0,94 & 0,95 & 0,95 & 0,95 & 1,00 & 0,96 & $1,68 \%$ \\
\hline $\mathbf{1 2}$ & 0,95 & 0,97 & 0,96 & 0,92 & 0,97 & 0,95 & $0,77 \%$ \\
\hline Média & $\mathbf{0 , 9 4}$ & $\mathbf{0 , 9 5}$ & $\mathbf{0 , 9 1}$ & $\mathbf{0 , 9 4}$ & $\mathbf{0 , 9 5}$ & $\mathbf{0 , 9 4}$ & $\mathbf{0 , 5 5 \%}$ \\
\hline
\end{tabular}

\begin{tabular}{|c|c|c|c|c|c|c|c|}
\hline \multicolumn{9}{|c|}{ GRUPO B - Estoque / REC } \\
\hline Empresa & $\mathbf{2 0 0 5}$ & $\mathbf{2 0 0 6}$ & $\mathbf{2 0 0 7}$ & $\mathbf{2 0 0 8}$ & $\mathbf{2 0 0 9}$ & $\begin{array}{c}\text { Estoque/REC } \\
\text { média }\end{array}$ & $\begin{array}{c}\text { Cresc. anual } \\
\text { médio (\%) }\end{array}$ \\
\hline $\mathbf{5}$ & 0,15 & 0,15 & 0,14 & 0,16 & 0,11 & 0,14 & $-5,57 \%$ \\
\hline $\mathbf{7}$ & 0,09 & 0,10 & 0,11 & 0,11 & 0,16 & 0,11 & $14,48 \%$ \\
\hline $\mathbf{9}$ & 0,09 & 0,10 & 0,09 & 0,14 & 0,11 & 0,10 & $8,95 \%$ \\
\hline $\mathbf{1 2}$ & 0,17 & 0,18 & 0,20 & 0,20 & 0,17 & 0,19 & $0,88 \%$ \\
\hline Média & $\mathbf{0 , 1 2}$ & $\mathbf{0 , 1 3}$ & $\mathbf{0 , 1 4}$ & $\mathbf{0 , 1 5}$ & $\mathbf{0 , 1 4}$ & $\mathbf{0 , 1 4}$ & $\mathbf{2 , 7 5 \%}$ \\
\hline
\end{tabular}




\begin{tabular}{|c|c|c|c|c|c|c|c|}
\hline \multicolumn{7}{|c|}{ GRUPO B - Imobilizado / REC } \\
\hline Empresa & $\mathbf{2 0 0 5}$ & $\mathbf{2 0 0 6}$ & $\mathbf{2 0 0 7}$ & $\mathbf{2 0 0 8}$ & $\mathbf{2 0 0 9}$ & $\begin{array}{c}\text { Imobilizado/REC } \\
\text { anual médio }\end{array}$ & $\begin{array}{c}\text { Cresc. anual } \\
\text { médio }(\boldsymbol{\%})\end{array}$ \\
\hline $\mathbf{5}$ & 0,14 & 0,13 & 0,11 & 0,15 & 0,15 & 0,13 & $4,52 \%$ \\
\hline $\mathbf{7}$ & 0,34 & 0,31 & 0,23 & 0,22 & 0,25 & 0,27 & $-6,37 \%$ \\
\hline $\mathbf{9}$ & 0,47 & 0,52 & 0,57 & 1,10 & 1,17 & 0,76 & $29,64 \%$ \\
\hline $\mathbf{1 2}$ & 0,07 & 0,09 & 0,10 & 0,08 & 0,14 & 0,10 & $22,21 \%$ \\
\hline Média & $\mathbf{0 , 2 5}$ & $\mathbf{0 , 2 6}$ & $\mathbf{0 , 2 5}$ & $\mathbf{0 , 3 9}$ & $\mathbf{0 , 4 3}$ & $\mathbf{0 , 3 2}$ & $\mathbf{1 5 , 7 7 \%}$ \\
\hline
\end{tabular}

\begin{tabular}{|c|c|c|c|c|c|c|c|}
\hline \multicolumn{9}{|c|}{ GRUPO B - Margem Operacional } \\
\hline Empresa & $\mathbf{2 0 0 5}$ & $\mathbf{2 0 0 6}$ & $\mathbf{2 0 0 7}$ & $\mathbf{2 0 0 8}$ & $\mathbf{2 0 0 9}$ & $\begin{array}{c}\text { MO anual } \\
\text { média }\end{array}$ & $\begin{array}{c}\text { Cresc. anual } \\
\text { médio (\%) }\end{array}$ \\
\hline $\mathbf{5}$ & $12,27 \%$ & $13,85 \%$ & $14,73 \%$ & $9,99 \%$ & $7,02 \%$ & $11,57 \%$ & \\
\hline $\mathbf{7}$ & $1,84 \%$ & $-2,10 \%$ & $13,35 \%$ & $-0,24 \%$ & $8,70 \%$ & $4,31 \%$ & \\
\hline $\mathbf{9}$ & $6,07 \%$ & $4,66 \%$ & $5,48 \%$ & $5,45 \%$ & $-0,26 \%$ & $4,28 \%$ & \\
\hline $\mathbf{1 2}$ & $5,46 \%$ & $3,18 \%$ & $4,14 \%$ & $7,94 \%$ & $2,75 \%$ & $4,70 \%$ & \\
\hline Média & $6,41 \%$ & $4,90 \%$ & $9,42 \%$ & $5,78 \%$ & $4,55 \%$ & $6,21 \%$ & \\
\hline
\end{tabular}

\begin{tabular}{|c|c|c|c|c|c|c|c|}
\hline \multicolumn{7}{|c|}{ GRUPO B - Rentabilidade Operacional } \\
\hline Empresa & $\mathbf{2 0 0 5}$ & $\mathbf{2 0 0 6}$ & $\mathbf{2 0 0 7}$ & $\mathbf{2 0 0 8}$ & $\mathbf{2 0 0 9}$ & $\begin{array}{c}\text { RO anual } \\
\text { média }\end{array}$ & $\begin{array}{c}\text { Cresc. anual } \\
\text { médio }(\boldsymbol{\%})\end{array}$ \\
\hline $\mathbf{5}$ & $18,11 \%$ & $19,89 \%$ & $24,47 \%$ & $17,70 \%$ & $12,04 \%$ & $18,44 \%$ & \\
\hline $\mathbf{7}$ & $2,31 \%$ & $-2,70 \%$ & $19,93 \%$ & $-0,35 \%$ & $9,71 \%$ & $5,78 \%$ & \\
\hline $\mathbf{9}$ & $6,32 \%$ & $4,69 \%$ & $5,89 \%$ & $4,48 \%$ & $-0,17 \%$ & $4,24 \%$ & \\
\hline $\mathbf{1 2}$ & $11,29 \%$ & $5,65 \%$ & $7,42 \%$ & $15,44 \%$ & $3,91 \%$ & $8,74 \%$ & \\
\hline Média & $9,51 \%$ & $6,88 \%$ & $14,43 \%$ & $9,32 \%$ & $6,37 \%$ & $9,30 \%$ & \\
\hline
\end{tabular}


SETOR SIDERURGIA/METALURGIA - GRUPO C

\begin{tabular}{|c|c|c|c|c|c|c|c|}
\hline \multicolumn{7}{|c|}{ GRUPO C - Receita líquida (em milhares de R\$) } \\
\hline Empresa & $\mathbf{2 0 0 5}$ & $\mathbf{2 0 0 6}$ & $\mathbf{2 0 0 7}$ & $\mathbf{2 0 0 8}$ & $\mathbf{2 0 0 9}$ & $\begin{array}{c}\text { Rec. Liquida } \\
\text { anual média }\end{array}$ & $\begin{array}{c}\text { Cresc. anual } \\
\text { médio (\%) }\end{array}$ \\
\hline $\mathbf{2}$ & 50,39 & 46,29 & 54,17 & 62,66 & 62,50 & 55,20 & $6,07 \%$ \\
\hline $\mathbf{8}$ & 342,71 & 183,93 & 151,96 & 329,05 & 215,08 & 244,55 & $4,55 \%$ \\
\hline $\mathbf{1 0}$ & 90,27 & 88,84 & 69,72 & 71,65 & 72,91 & 78,68 & $-4,64 \%$ \\
\hline $\mathbf{1 3}$ & 205,84 & 121,94 & 169,87 & 116,99 & 127,80 & 148,49 & $-5,83 \%$ \\
\hline Média & $\mathbf{1 7 2 , 3 0}$ & $\mathbf{1 1 0 , 2 5}$ & $\mathbf{1 1 1 , 4 3}$ & $\mathbf{1 4 5 , 0 9}$ & $\mathbf{1 1 9 , 5 7}$ & $\mathbf{1 3 1 , 7 3}$ & $\mathbf{- 5 , 5 8 \%}$ \\
\hline
\end{tabular}

\begin{tabular}{|c|c|c|c|c|c|c|c|}
\hline \multicolumn{9}{|c|}{ GRUPO C - CDT / REC } \\
\hline Empresa & $\mathbf{2 0 0 5}$ & $\mathbf{2 0 0 6}$ & $\mathbf{2 0 0 7}$ & $\mathbf{2 0 0 8}$ & $\mathbf{2 0 0 9}$ & $\begin{array}{c}\text { CDT anual } \\
\text { média }\end{array}$ & $\begin{array}{c}\text { Cresc. anual } \\
\text { médio (\%) }\end{array}$ \\
\hline $\mathbf{2}$ & 1,01 & 1,19 & 1,19 & 1,01 & 1,16 & 1,11 & $4,41 \%$ \\
\hline $\mathbf{8}$ & 1,01 & 1,24 & 1,20 & 0,87 & 0,98 & 1,06 & $1,07 \%$ \\
\hline $\mathbf{1 0}$ & 0,98 & 1,07 & 1,03 & 1,16 & 1,14 & 1,07 & $4,24 \%$ \\
\hline $\mathbf{1 3}$ & 0,93 & 0,94 & 1,00 & 1,01 & 1,44 & 1,06 & $12,69 \%$ \\
\hline Média & $\mathbf{0 , 9 8}$ & $\mathbf{1 , 1 1}$ & $\mathbf{1 , 1 0}$ & $\mathbf{1 , 0 1}$ & $\mathbf{1 , 1 8}$ & $\mathbf{1 , 0 8}$ & $\mathbf{5 , 2 0 \%}$ \\
\hline
\end{tabular}

\begin{tabular}{|c|c|c|c|c|c|c|c|}
\hline \multicolumn{7}{|c|}{ GRUPO C - Estoque / REC } \\
\hline Empresa & $\mathbf{2 0 0 5}$ & $\mathbf{2 0 0 6}$ & $\mathbf{2 0 0 7}$ & $\mathbf{2 0 0 8}$ & $\mathbf{2 0 0 9}$ & $\begin{array}{c}\text { Estoque/REC } \\
\text { média }\end{array}$ & $\begin{array}{c}\text { Cresc. anual } \\
\text { médio }(\mathbf{\%})\end{array}$ \\
\hline $\mathbf{2}$ & 0,90 & 0,92 & 0,72 & 0,67 & 0,75 & 0,79 & $-3,56 \%$ \\
\hline $\mathbf{8}$ & 0,21 & 0,27 & 0,30 & 0,18 & 0,24 & 0,24 & $7,10 \%$ \\
\hline $\mathbf{1 0}$ & 0,09 & 0,14 & 0,19 & 0,20 & 0,21 & 0,17 & $24,13 \%$ \\
\hline $\mathbf{1 3}$ & 0,15 & 0,19 & 0,14 & 0,12 & 0,15 & 0,15 & $2,20 \%$ \\
\hline Média & $\mathbf{0 , 3 4}$ & $\mathbf{0 , 3 8}$ & $\mathbf{0 , 3 4}$ & $\mathbf{0 , 2 9}$ & $\mathbf{0 , 3 4}$ & $\mathbf{0 , 3 4}$ & $\mathbf{0 , 6 3 \%}$ \\
\hline
\end{tabular}




\begin{tabular}{|c|c|c|c|c|c|c|c|}
\hline \multicolumn{7}{|c|}{ GRUPO C - Imobilizado / REC } \\
\hline Empresa & $\mathbf{2 0 0 5}$ & $\mathbf{2 0 0 6}$ & $\mathbf{2 0 0 7}$ & $\mathbf{2 0 0 8}$ & $\mathbf{2 0 0 9}$ & $\begin{array}{c}\text { Imobilizado/REC } \\
\text { anual médio }\end{array}$ & $\begin{array}{c}\text { Cresc. anual } \\
\text { médio }(\boldsymbol{\%})\end{array}$ \\
\hline $\mathbf{2}$ & 1,24 & 1,38 & 1,18 & 0,99 & 0,99 & 1,16 & $-4,9 \%$ \\
\hline $\mathbf{8}$ & 0,42 & 0,72 & 0,79 & 0,32 & 0,45 & 0,54 & $15,6 \%$ \\
\hline $\mathbf{1 0}$ & 0,20 & 0,23 & 0,30 & 0,32 & 0,30 & 0,27 & $10,6 \%$ \\
\hline $\mathbf{1 3}$ & 0,06 & 0,15 & 0,14 & 0,09 & 0,19 & 0,13 & $57,3 \%$ \\
\hline Média & $\mathbf{0 , 4 8}$ & $\mathbf{0 , 6 2}$ & $\mathbf{0 , 6 0}$ & $\mathbf{0 , 4 3}$ & $\mathbf{0 , 4 8}$ & $\mathbf{0 , 5 2}$ & $\mathbf{2 , 4 5 \%}$ \\
\hline
\end{tabular}

\begin{tabular}{|c|c|c|c|c|c|c|c|}
\hline \multicolumn{9}{|c|}{ GRUPO C - Margem Operacional } \\
\hline \multirow{2}{*}{ Empresa } & $\mathbf{2 0 0 5}$ & $\mathbf{2 0 0 6}$ & $\mathbf{2 0 0 7}$ & $\mathbf{2 0 0 8}$ & $\mathbf{2 0 0 9}$ & $\begin{array}{c}\text { MO anual } \\
\text { média }\end{array}$ & $\begin{array}{c}\text { Cresc. anual } \\
\text { médio (\%) }\end{array}$ \\
\hline $\mathbf{2}$ & $-0,85 \%$ & $-19,29 \%$ & $-18,99 \%$ & $-1,15 \%$ & $-15,93 \%$ & $-11,24 \%$ & \\
\hline $\mathbf{8}$ & $-1,01 \%$ & $-23,81 \%$ & $-19,53 \%$ & $12,91 \%$ & $2,18 \%$ & $-5,85 \%$ & \\
\hline $\mathbf{1 0}$ & $2,31 \%$ & $-6,55 \%$ & $-2,69 \%$ & $-15,51 \%$ & $-14,40 \%$ & $-7,37 \%$ & \\
\hline $\mathbf{1 3}$ & $7,01 \%$ & $5,64 \%$ & $0,02 \%$ & $-1,22 \%$ & $-43,85 \%$ & $-6,48 \%$ & \\
\hline Média & $1,86 \%$ & $-11,00 \%$ & $-10,30 \%$ & $-1,24 \%$ & $-18,00 \%$ & $-7,74 \%$ & \\
\hline
\end{tabular}

\begin{tabular}{|c|c|c|c|c|c|c|c|}
\hline \multicolumn{7}{|c|}{ GRUPO C - Rentabilidade Operacional } \\
\hline Empresa & $\mathbf{2 0 0 5}$ & $\mathbf{2 0 0 6}$ & $\mathbf{2 0 0 7}$ & $\mathbf{2 0 0 8}$ & $\mathbf{2 0 0 9}$ & $\begin{array}{c}\text { RO anual } \\
\text { média }\end{array}$ & $\begin{array}{c}\text { Cresc. anual } \\
\text { médio }(\boldsymbol{\%})\end{array}$ \\
\hline $\mathbf{2}$ & $-0,27 \%$ & $-5,68 \%$ & $-6,52 \%$ & $-0,44 \%$ & $-5,88 \%$ & $-3,76 \%$ & \\
\hline $\mathbf{8}$ & $-0,83 \%$ & $-11,23 \%$ & $-8,40 \%$ & $10,48 \%$ & $1,12 \%$ & $-1,77 \%$ & \\
\hline $\mathbf{1 0}$ & $3,35 \%$ & $-8,37 \%$ & $-2,55 \%$ & $-15,18 \%$ & $-14,82 \%$ & $-7,51 \%$ & \\
\hline $\mathbf{1 3}$ & $18,92 \%$ & $6,75 \%$ & $0,03 \%$ & $-1,02 \%$ & $-35,78 \%$ & $-2,22 \%$ & \\
\hline Média & $5,29 \%$ & $-4,63 \%$ & $-4,36 \%$ & $-1,54 \%$ & $-13,84 \%$ & $-3,82 \%$ & \\
\hline
\end{tabular}

